\title{
VARIABILIDADE GENÉTICA EM ESPÉCIES DE Anastrepha DO GRUPO fraterculus (DIPTERA; TEPHRITIDAE) ATRAVÉS DO SEQÜENCIAMENTO DE GENES DO DNA MITOCONDRIAL E ANÁLISE DE RFLP
}

\section{Martha Rocío Bressan SMith-Caldas}

Bacharel em Biologia

Orientador: Prof. Dr. ROBERTO A. ZUCCHI Co-orientador: Prof. Dr. BRUCE A. McPHERON

\begin{abstract}
Tese apresentada à Escola Superior de Agricultura "Luiz de Queiroz", Universidade de São Paulo, para obtenção do título de Doutor em Agronomia. Área de Concentração: Entomologia.
\end{abstract}

\section{PIRACICABA}

Estado de São Paulo - Brasil

Janeiro - 2001 
Dados Internacionais de Catalogação na Publicação (CIP)

DIVISÃo DE BIBLIOTECA E DOCUMENTAÇÃO - Campus "Luiz de Queiroz"/USP

\section{Smith-Caldas, Martha Rocío Bressan}

Variabilidade genética em espécie de $A$ nastrepha do grupo fraterculus (Diptera; Tephritidae) através do seqüenciamento de genes do DNA mitocondrial e análise de RFLP / Matha Rocio Bressan Smith-Caldas. -- Piracicaba, 2001.

100 p. : il.

Tese (doutorado) - - Escola Superior de Agricultura Luiz de Queiroz, 2001.

Bibliografia.

1. DNA mitocondrial 2. Gene 3. Mosca-das-frutas 4. RFLP 5. Sequência de DNA 6. Variabilidade genética I. Título

CDD 632.774

\section{Sernitida a céna total ou parcial deste documento, desde que citala a fonte- O autor:}


Aos meus filhos,

Amanda e Gabriel.

\section{DEDICO}




\section{AGRADECIMENTOS}

Sem dúvida, muitas são as pessoas a serem lembradas nesta hora. Pessoas que nos acompanharam nestes quatro anos, com as quais convivemos, aprendemos e crescemos como cientista e como ser humano.

Ao Prof. Dr. Roberto Antonio Zucchi pela oportunidade de conduzir este trabalho, e de me introduzir ao mundo fascinante das moscas-das-frutas. Além disso, seu apoio e compreensão foram essenciais para a finalização deste trabalho.

Ao Prof. Dr. Bruce McPheron, uma das pessoas que mais acreditou no meu potencial, ampliou minha visão de ciência e teve atitudes verdadeiramente paternais para comigo e minha família.

À Janisete Gomes da Silva, que acompanhou este trabalho deste o início e, com quem além de aprender técnicas moleculares, tive a dádiva de desenvolver uma amizade sólida e sincera.

Meu marido, Marcellus, merece um agradecimento especial, não só por não me deixar esmorecer nas dificuldades, mas por agüentar bravamente uma esposa, mãe e doutoranda muitas vezes preocupada e dividida.

Aos meus pais e irmãos, que acompanharam atenciosamente todo o processo, torceram, e me deram força nos momentos mais difíceis.

À Elton Araujo, Gary Steck, Jayme Piñero, Keiko Uramoto, Martin Aluja e Miguel de Souza Filho que gentilmente cederam as amostras que foram utilizadas neste trabalho. Definitivamente a ajuda dessas pessoas foi de fundamental importância. 
À Dietmar Schwarz e Norman Barr pelo auxílio nas análises estatísticas.

A Dr. Guy L. Bush e Dr. James Smith que me receberam de braços abertos em seu laboratório na Michigan State University, com os quais tive a oportunidade de conviver, produzir e aprender as técnicas básicas em biologia molecular, graças a ajuda de Vesna Gravilovki e Matt Jaycox.

Aos professores do Departamento de Entomologia, os quais servirão de exemplo em meu retorno as atividades didáticas. Em especial ao Prof. Dr. Sinval Silveira Neto e sua família pelo carinho e amizade.

Aos colegas de curso, da ESALQ e da Penn State, que definitivamente passaram a fazer parte de minha vida. Nomeá-los seria injusto, mas aqueles com quem formamos equipe, fizemos disciplina, dividimos bancada ou simplesmente fomos cúmplices em idéias, recebam meu carinho especial.

Aos funcionários do Departamento de Entomologia, sempre dispostos a ajudar e facilitar nossas vidas.

Aos amigos de Piracicaba, de East Lansing e State College, que receberam minha família como parte de suas famílias.

A Universidade Estadual de Santa Cruz e a CAPES, pela bolsa recebida.

A conclusão deste trabalho e a incrível oportunidade que tivemos de conhecer tanta gente maravilhosa não seria possível sem a graça e benevolência de Deus. Nas mãos Dele eu me coloquei e em todos os momentos por Ele fui conduzida. 


\section{SUMÁRIO}

\section{Página}

LISTA DE FIGURAS ….............................................................................. viii

LISTA DE TABELAS …..........................................................................

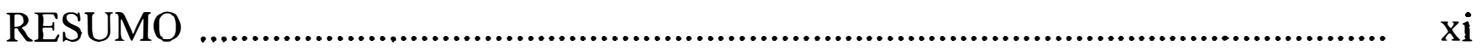

SUMMARY ....................................................................................... xii

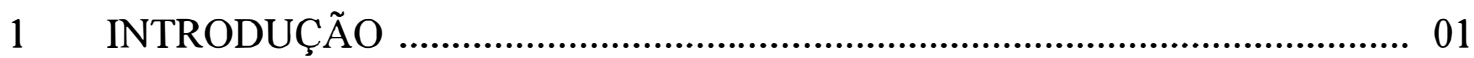

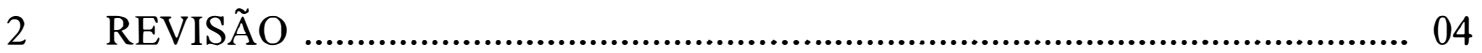

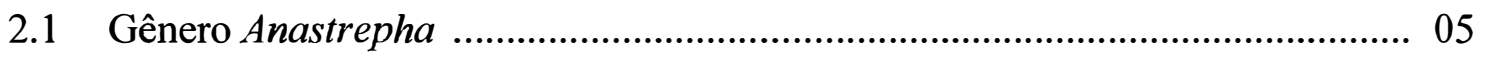

2.2 Grupo fraterculus .......................................................................... 08

2.3 Complexo fraterculus ......................................................................... 10

2.4 Variabilidade genética .................................................................. 15

2.5 DNA mitocondrial (DNAmt) ............................................................. 16

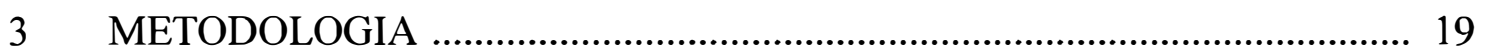

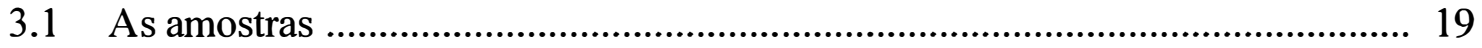

3.2 Regiões do DNAmt analisadas ............................................................. 26

3.3 Extração de DNA total ............................................................................ 26

3.4 Reação da polimerase em cadeia (PCR) ....................................................... 27

3.5 Padrões de fragmentos obtidos por digestão por enzimas de restrição (RFLP) .......................................................................................... 29

3.6 Seqüenciamento ................................................................................... 30

3.7 Análise filogenética .............................................................................. 31

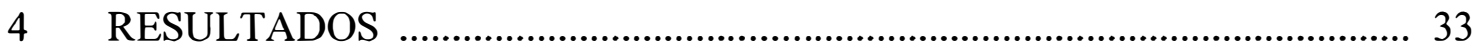

4.1 Relações filogenéticas entre espécies do grupo fraterculus ............................. 33

4.1.1 Gene COI ......................................................................................... 33 


\section{Página}

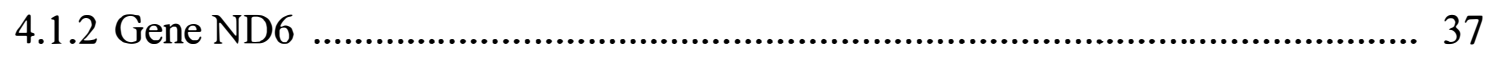

4.1.3 Análise conjunta dos genes COI e ND6 .................................................... 39

4.1.4 Análise conjunta dos genes COI e 16S ........................................................... 41

4.2 Variabilidade genética na espécie nominal $A$. fraterculus análise de PCR-RFLP ............................................................................... 43

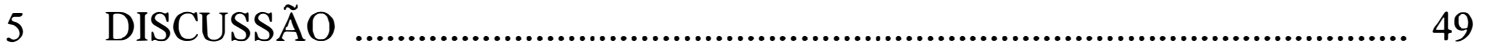

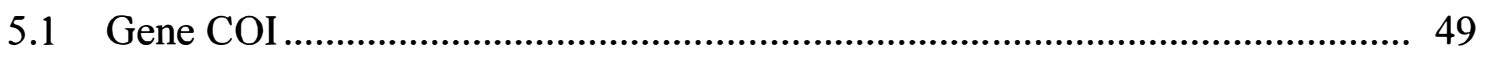

5.2 Gene ND6 …............................................................................. 54

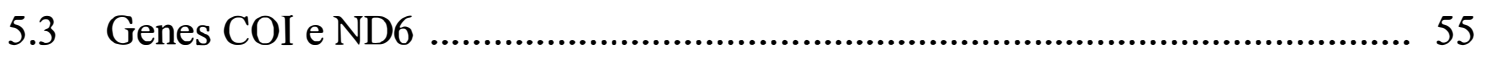

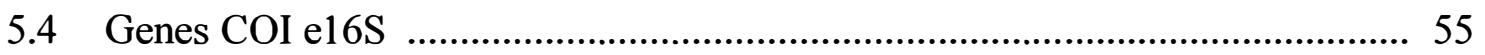

5.5 Caracteres morfológicos e dados moleculares .............................................. 57

5.6 Variação interpopulacional ....................................................................... 59

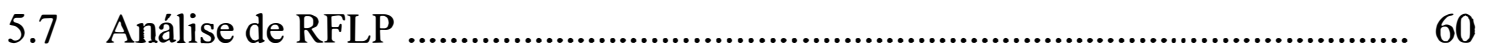

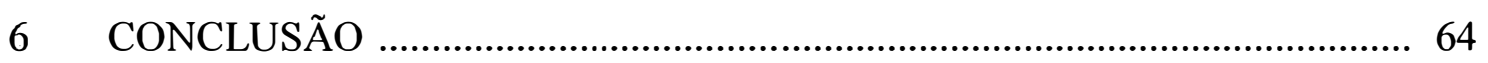

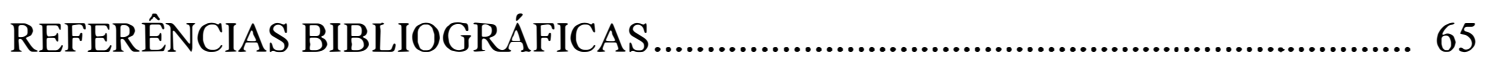

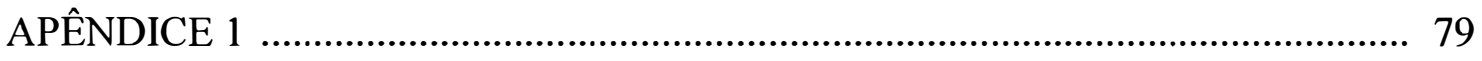

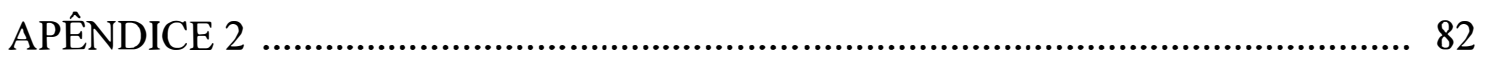

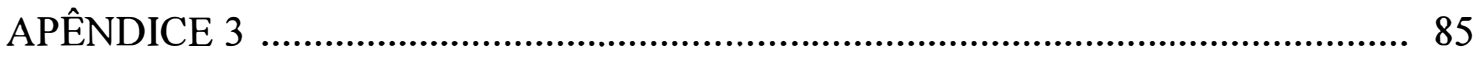




\section{LISTA DE FIGURAS}

Página

1 Mapa circular do DNAmt de Drosophila yakuba mostrando a localização e direção da transcrição dos genes ................................................ 26

2 Relações filogenéticas entre espécies do grupo fraterculus inferidas pelo método de $\mathrm{NJ}$ baseada na distância genética de Jukes-Cantor, para o gene COI

3 Relações filogenéticas entre espécies do grupo fraterculus inferidas pelo método de MP para o gene COI.

4 Relações filogenéticas entre espécies do grupo fraterculus inferidas para o gene ND6, com base no método de NJ e distância genética de Jukes-Cantor

5 Relações filogenéticas entre espécies do grupo fraterculus inferidas pelo método de $\mathrm{NJ}$ baseada na distância genética de Jukes-Cantor, para a análise conjunta dos genes COI e ND6.

6 Filograma gerado pelo método de $\mathrm{NJ}$, baseado na distância genética de Jukes-Cantor, para os genes COI e 16S

7 Fragmentos resultantes da digestão enzimática da região intergênica por Psi I para exemplares de $A$. fraterculus evidenciando variação interpopulacional

8 Mapas de restrição do DNAmt para a enzima Psi I correspondente a região compreendida entre os genes COI e COII, para os diferentes padrões, gerados pelo progrma Omiga (Oxford Molercular, 1999)

9 Distribuição geográfica dos padrões gerados pela enzima de restrição $P s i$ I, para a região intergênica, com ênfase ao Estado de São Paulo 
10 Fragmentos resultantes da digestão enzimática da região intergênica por Psi I para exemplares de $A$. fraterculus das populações que apresentaram variação intrapopulacional 48 


\section{LISTA DE TABELAS}

Página

1 Espécies e populações de Anastrepha analisadas para o gene COI .................... 20

2 Espécies e populações de Anastrepha analisadas para o gene ND6 ................... 22

3 Espécies e populações de Anastrepha analisadas para o gene 16S ..................... 23

4 Populações de Anastrepha fraterculus analisadas através da enzima de restrição Psi I ............................................................................................ 24

5 Oligonucleotídeos iniciadores ("primers") usados nas reações de amplificação via PCR e seqüenciamento

6 Programas de termociclador utilizados para os diferentes pares de "primers"

7 Padrões de restrição estabelecidos pela enzima $P_{s i}$ I, sua distribuição nas populações estudadas, a variação de tamanho constatada na região intergênica e o número total de pares de base da região compreendida entre parte dos genes COI e COII em cada um dos padrões 


\title{
VARIABILIDADE GENÉTICA EM ESPÉCIES DE Anastrepha DO GRUPO fraterculus (DIPTERA; TEPHRITIDAE) ATRAVÉS DO SEQÜENCIAMENTO DE GENES DO DNA MITOCONDRIAL E RFLP
}

\author{
Autora: MARTHA ROCIO BRESSAN SMITH-CALDAS \\ Orientador: Prof. ROBERTO ANTONIO ZUCCHI \\ Co-orientador: Prof. BRUCE A. McPHERON
}

\section{RESUMO}

Algumas espécies de moscas-das-frutas são importantes pragas agrícolas. Dentre as que causam maior prejuízo estão algumas espécies do grupo fraterculus, do qual faz parte a espécie nominal $A$. fraterculus, considerada por vários autores um complexo de espécies crípticas. Com o objetivo de esclarecer as relações genéticas entre algumas das espécies deste grupo, quinze espécies foram analisadas: doze pertencentes ao grupo fraterculus, uma sem grupo morfologicamente definido e duas tomadas como grupos externos. Para as espécies que compõem o grupo fraterculus parte dos genes mitocondriais citocromo oxidase subunidade I (COI), NADH desidrogenase subunidade 6 (ND6) e a subunidade 16S de RNA ribossômico (16S) foram seqüenciados e analisados filogeneticamente. As populações da espécie nominal $A$. fraterculus foram analisadas através de enzima de restrição com posterior seqüenciamento dos diferentes padrões. A análise individual e em conjunto dos diferentes genes indicam a nãomonofilia do grupo fraterculus com a possibilidade de existência de múltiplos conjuntos gênicos. Nas árvores geradas pelos diferentes métodos, A. barbiellinii mostrou-se separada das demais espécies do grupo fraterculus evidenciando a necessidade de 
revisão da colocação dessa no grupo. A. acris, espécie sem grupo morfologicamente definido, de acordo com os dados desse trabalho, encaixa-se dentro dos limites do grupo fraterculus. Fica clara a necessidade em revisar a colocação das espécies $A$. acris e $A$. barbiellinii no grupo fraterculus. Na região compreendida entre os genes COI e COII, estudada para a caracterização das populações de $A$. fraterculus constatou-se a ocorrência de uma região intergênica entre os genes tRNA ${ }^{\text {Leu }}$ e COII. A enzima Psi I, utilizada nessa região gerou cinco padrões de restrição e foi constatada variação inter e intrapopulacional. 


\title{
GENETIC VARIABILITY IN Anastrepha SPECIES OF THE fraterculus GROUP (DIPTERA: TEPHRITIDAE) INFERRED FROM MITOCHONDRIAL DNA GENE SEQUENCES AND RFLP
}

\author{
Author: MARTHA ROCIO BRESSAN SMITH-CALDAS \\ Advisor: Prof. ROBERTO ANTONIO ZUCCHI \\ Co-Advisor: Prof. BRUCE A. McPHERON
}

\section{SUMMARY}

The fruit flies in the genus Anastrepha are among some of the most destructive agricultural pests. Some of these economically important species are within the fraterculus group, to which belongs the nominal species $A$. fraterculus, actually considered a complex of cryptic species by several authors. In order to resolve the genetic relationships among some species within this group, 15 species were analyzed: 12 within the fraterculus group, one unplaced species and two outgroups. Sequences were obtained for part of the mitochondrial genes cytochrome oxydase I (COI), NADH dehidrogenase subunit 6 (ND6) and the large subunit rimossomal RNA (16S) for all the species studied. Phylogenetic relationships among the included taxa were inferred using neighbor-joining and maximum parsimony methods. Different populations within the nominal species A. fraterculus were analyzed using polimerase chain reaction Restriction fragment lenght polymorphism (PCR-RFLP) and individuals that showed different restriction patterns were sequenced. The individual and combined analyses of the different mtDNA genes indicate the non monophyly of the fraterculus group and the existence of multiple gene pools. A. barbiellinii lies outside the limit of the fraterculus 
group and its inclusion in this group should be reexamined. A. acris, an unplaced species based on morphological characters, is included in the fraterculus group on the basis of the data presented in this study. The region comprised between the COI and COII genes was studied in order to characterize the different populations of $A$. fraterculus and the results showed the presence of an intergenic region between the tRNA ${ }^{\text {Leu }}$ and COII genes. Five patterns were generated by the digestions of this region with the restriction enzyme $P S i$ I and inter and intrapopulational variation was found. 


\section{INTRODUÇÃO}

As moscas-das-frutas da família Tephritidae estão entre as principais pragas da fruticultura mundial, tanto pelos danos diretos aos frutos, quanto pelos danos indiretos, influenciando negativamente a comercialização no mercado externo, principalmente para países onde estas pragas não ocorrem (Ortiz, 1999).

No Brasil, as espécies do gênero Anastrepha são muito importantes do ponto de vista agrícola. Esse gênero é constituído por 197 espécies (Norrbom et al., 1999), das quais 94 ocorrem no Brasil (Zucchi, 2000a). O gênero Anastrepha tem sido dividido em vários grupos, entre os quais encontra-se o grupo fraterculus com 29 espécies (Norrbom et al, 1999). Desse grupo faz parte A. fraterculus (Wied., 1830), que tem sido considerada um complexo de espécies crípticas.

O conhecimento da variabilidade genética é de especial importância na implementação de programas de manejo de pragas. Esse conhecimento permite estabelecer a ocorrência espacial e temporal de insetos, a escolha da melhor estratégia de manejo, a análise da eficiência do método utilizado no controle e a possibilidade de desenvolvimento de resistência pela praga (Kennedy, 1993).

Os marcadores moleculares podem ser utilizados com sucesso como indicadores de processos evolutivos. Apesar de serem aplicados após outras observações terem indicado a existência de heterogeneidade entre populações ou espécies, os estudos moleculares podem esclarecer questões que permaneceram inconclusivas, quando analisadas por métodos tradicionais (Kim \& McPheron, 1993). 
Considerando-se a existência do complexo fraterculus de espécies crípticas, questões como distribuição das espécies, diferenças comportamentais e preferência por hospedeiros, devem ser esclarecidas a fim de que medidas quarentenárias e de controle sejam aplicadas. A técnica do macho estéril tem sido utilizada com sucesso em programas de erradicação e o claro entendimento da sistemática do complexo fraterculus é necessário e essencial no que se refere a liberação de indivíduos que sejam geneticamente compatíveis com as espécies presentes na área tratada (Steck, 1999). No que concerne a medidas quarentenárias, uma identificação acurada da espécie de moscas-das-frutas é decisiva na liberação da exportação de frutas (Armstrong et al., 1997).

A similaridade morfológica apresentada por algumas espécies do grupo fraterculus e a carência de caracterização genética foram a razão para o desenvolvimento deste trabalho.

As técnicas de seqüenciamento direto e enzimas de restrição foram utilizadas neste estudo a fim de tentar esclarecer as complexas relações entre algumas das espécies do grupo fraterculus e do complexo fraterculus. Atualmente, o avanço de técnicas moleculares permite a avaliação detalhada do DNA, sendo, portanto, mais um instrumento para o estudo da biologia, ecologia e genética de populações de insetos. A análise dos genes mitocondriais citocromo oxidase I (COI), gene que codifica para a subunidade 6 da NADH desidrogenase (ND6) e parte do gene RNA ribossômico (rRNA) $16 \mathrm{~S}$, e a enzima de restrição Psil foram utilizadas na tentativa de esclarecer essas questões.

Os principais objetivos deste trabalho foram inferir as relações genéticas entre as espécies do grupo fraterculus, analisando os limites específicos das espécies estudadas pela comparação dos dados moleculares com morfológicos e foi pesquisada a possibilidade de ocorrência de um complexo de espécies crípticas, em vista das heterogeneidades morfológicas, biológicas e genéticas da espécie nominal A. fraterculus ao longo da sua distribuição geográfica. 
Diante do exposto, torna-se claro que estudos de natureza taxonômica, molecular, ecológica ou biológica são de extrema importância para o entendimento desse grupo de insetos (Aluja, 1994). 


\section{REVISÃO DE LITERATURA}

No Brasil, além do gênero Anastrepha, ocorrem os gêneros Ceratitis MacLeay, Bactrocera Macquart, Rhagoletis Loew e Toxotrypana Gerstaecker (Zucchi, 2000a).

O gênero Ceratitis, endêmico da África tropical, é representado no Brasil por uma única espécie, Ceratitis capitata (Wied., 1824), que infesta preferencialmente frutos introduzidos (Malavasi et al., 1980).

O gênero Bactrocera é endêmico da Ásia, Austrália e Pacífico Sul (White \& Elson-Harris, 1992). No Brasil, uma única espécie desse gênero, B. carambolae Drew \& Hancock, 1994, foi reportada pela primeira vez em 1996, no Estado do Amapá, tendo sido inicialmente introduzida no Suriname (Malavasi, 1996). A implementação da técnica de aniquilação de machos está sendo empregada com sucesso contra $B$. carambolae. O Estado do Amapá e a região oeste do Suriname já se encontram livres dessa praga (Malavasi, 2000).

O gênero Rhagoletis, que ocorre na Europa, Américas do Norte, Central e do Sul, é representado no Brasil por quatro espécies: $R$. adusta Foote, $R$. blanchardi Aczél, $R$. ferruginea Hendel e $R$. macquarti (Loew), que não apresentam importância econômica (Zucchi, 2000a).

Do gênero Toxotrypana, cuja distribuição abrange as Américas do Norte, Central e do Sul, apenas espécies sem importância econômica foram registradas no Brasil, não ocorrendo, portanto, T. curvicauda Gerstaecker, praga do mamão, na Colômbia e na Venezuela (Zucchi, 2000a; Malavasi et al., 2000). 
Considerando-se as restrições quarentenárias aos países produtores de frutas impostas pelo mercado mundial, são de extrema importância o conhecimento da biologia, ecologia e genética das moscas-das-frutas (McPheron, 1993). Os países importadores adotam rigorosos sistemas de quarentena, não permitindo a entrada de frutos com sinais de infestação ou provenientes de áreas onde as espécies-praga ocorrem em níveis populacionais acima dos limites pré-estabelecidos (Malavasi, 2000).

Quaisquer medidas que visem o controle de insetos-praga, devem ser compatíveis com o patrimônio genético da espécie em questão (McPheron, 1993).

\subsection{Gênero Anastrepha}

O gênero Anastrepha Schiner ocorre do sul dos Estados Unidos ao norte da Argentina, incluindo a maioria das ilhas do Caribe (Stone, 1942; Aluja, 1994). As espécies desse gênero são identificadas por características da carena facial, do mediotergito e subescutelo, do sintergosternito VII e da membrana eversível, pelo padrão alar característico com as faixas alares costal, em $\mathrm{S}$ e em $\mathrm{V}$ invertido e, principalmente, pela morfologia do ápice do acúleo que apresenta pequenas diferenças no formato (Zucchi, 2000a)

Raramente os estágios imaturos podem ser utilizados na identificação, já que somente larvas de algumas espécies de importância econômica foram estudadas e descritas. Entretanto, a variação morfológica nas larvas parece ser maior do que se supunha (Foote et al., 1993). Armstrong et al. (1997), estudando as regiões do gene nuclear de rRNA $18 \mathrm{~S}$ e espaço interno transcrito (ITS), desenvolveram um protocolo molecular para larvas de tefritídeos baseado em PCR-RFLP (reação da polimerase em cadeia seguido de digestão por enzimas de restrição). Esse protocolo, utilizando quatro enzimas de restrição, gerou haplótipos diagnósticos para algumas espécies de Bactrocera que podem assim ser identificadas, sendo algumas de importância quarentenária. 
Algumas das espécies de Anastrepha são especialistas, estando relacionadas à uma família botânica em particular como A. grandis Macquart, 1845, que infesta algumas espécies da família Cucurbitaceae e A. barbiellinii Lima, 1938 que só foi registrada infestando uma única espécie de Cactaceae. No outro extremo, estão espécies generalistas como $A$. fraterculus e $A$. obliqua (Macquart, 1835). No Brasil, $A$. fraterculus foi descrita infestando 17 famílias, num total de 67 espécies, e $A$. obliqua infesta 27 espécies botânicas pertencentes a cinco famílias (Zucchi, 2000b). Apesar do gênero Anastrepha não ser suficientemente antigo para que as espécies tenham coevoluído com os hospedeiros, é possível que exista uma correlação entre filogenia e hospedeiros (Norrbom, 1985).

De maneira geral, os adultos de espécies incluídas neste gênero são altamente fecundos, móveis, com tempo de vida longo e utilizam diferentes hospedeiros que frutificam durante o ano (Malavasi \& Morgante, 1980).

Segundo Aluja (1994), das espécies de Anastrepha descritas, sete são de importância econômica: A. fraterculus, A. obliqua, A. grandis, A. serpentina (Wied., 1830), A. striata Schiner, 1868, A. suspensa (Loew, 1873) e A. ludens (Loew, 1873). No Brasil, além de: A. fraterculus, A. obliqua, A. grandis e A. striata, A. pseudoparallela (Loew, 1873), A. sororcula Zucchi, 1979 e A. zenildae Zucchi, 1979 também são importantes do ponto de vista econômico (Zucchi, 2000a).

A importância econômica dessas espécies é variável ao longo de sua distribuição. Por exemplo, A. fraterculus é espécie de distribuição ampla, contudo, só apresenta "status" de praga primária no Brasil (regiões sudeste e sul), na Argentina e no Uruguai. A. striata apresenta maior importância econômica na América Central. A. obliqua também apresenta ampla distribuição, contudo, é tida como praga secundária ao longo de sua distribuição, exceto no sul do Caribe. As espécies $A$. suspensa e $A$. ludens não ocorrem no Brasil, mas devido ao tráfego de pessoas e produtos representam um perigo potencial para o país (Malavasi et al., 2000). 
As espécies do gênero Anastrepha, no Brasil, infestam preferencialmente frutos nativos. Apenas 44\% das espécies de Anastrepha que ocorrem no Brasil já foram associadas aos seus hospedeiros, sendo que para $20 \%$ destas, apenas um hospedeiro é conhecido. $\mathrm{O}$ uso de armadilhas nos levantamentos é responsável por esse quadro, pois representa uma barreira para o conhecimento das interações inseto-hospedeiro, uma vez que permite o conhecimento da existência do inseto em determinado local, mas não a associação segura com o hospedeiro (Zucchi, 2000b).

A ocorrência de complexos de espécies crípticas tem sido registrada em diferentes gêneros da família Tephritidae (White \& Elson-Harris, 1992). Um exemplo muito conhecido ocorre no gênero Rhagoletis, em particular o complexo R. pomonella, que tem sido estudado sob a perspectiva de genética de populações, sistemática e biologia evolutiva. Desse estudo resultou a identificação de espécies crípticas associadas a hospedeiros, a evidência genética na formação de raças-hospedeiro (um clássico exemplo de especiação simpátrica) e demonstração da variação latitudinal em porções do genoma ligadas a associações com hospedeiros (White \& Elson-Harris, 1992; McPheron, 1998).

Outros exemplos de complexos de espécies crípticas na família Tephritidae incluem o gênero Bactrocera, com o complexo B. dorsalis que possui no mínimo 52 espécies (Drew \& Hancock, 1994; Haymer \& He, 1998), o gênero Rhagoletis, com os complexos $R$. tabellaria e $R$. cingulata, além dos complexos nos gêneros Blepharoneura, Chaetorellia, Tephritis e Urophora (White \& Elson-Harris, 1992; Condon \& Steck, 1997).

No grupo fraterculus, encontram-se as principais espécies de importância econômica para o Brasil. Nesse grupo, como já apontado por vários autores, ocorrem espécies crípticas. Mayr (1970) definiu espécies crípticas como "populações morfologicamente similares ou idênticas, isoladas reprodutivamente". A esta definição, Futuyma (1996) acrescentou que espécies crípticas "são indistinguíveis morfologicamente, contudo diferem em outras características biológicas e não se 
intercruzam" e deu como exemplos diferenças nos cromossomos e em características ecológicas. $\mathrm{O}$ estudo de espécies crípticas permite testar a validade de conceitos biológicos versus morfológicos e elaborar modelos em estudos de especiação (Mayr, 1970).

McPheron (1998) explicou de maneira clara a importância do estudo e reconhecimento de espécies crípticas com relação ao controle de pragas, particularmente quando se refere às moscas-das-frutas. Observou que se essas espécies são suficientemente diferentes para não se intercruzarem, os métodos de manejo que visem a biologia reprodutiva de uma determinada espécie, poderão não ser bem sucedidos para outras espécies que façam parte do mesmo grupo.

Segundo Mayr (1970), a existência de espécies crípticas é bastante comum entre insetos, mas a descoberta dessas espécies é muita lenta e principalmente são estudados grupos com espécies de importância agrícola ou médica.

A mais recente revisão da distribuição de grupos no gênero Anastrepha foi feita por Norrbom et al. (1999), que caracterizaram 17 grupos de espécies neste gênero, entre eles o grupo fraterculus. Entretanto, várias espécies permanecem sem grupo definido.

Considerando-se o grande número de espécies no gênero Anastrepha, a descoberta de novas espécies que têm sido descritas e a presença de muitas espécies crípticas, futuras classificações infragenéricas deverão se basear em uma combinação de critérios como morfologia, citogenética, estudos isozímicos, análises moleculares (DNA) e também em um maior conhecimento da ecologia e do comportamento das espécies (Aluja, 1994).

\subsection{Grupo fraterculus}

Stone (1942), em sua revisão do gênero Anastrepha, relacionou espécies próximas à $A$. fraterculus com base em caracteres morfológicos, principalmente no 
padrão alar, cunhando o termo complexo fraterculus. Observou ainda que "há um grande número de espécies que são muito próximas de $A$. fratérculus e nesta parte do gênero reside a maior dificuldade em determinar os limites específicos".

Korytkowski \& Ojeda (1968) conduziram um amplo estudo do gênero Anastrepha com exemplares coletados no noroeste do Peru. Aqueles autores agruparam, com base em caracteres morfológicos, as 35 espécies coletadas em dez grupos. Assim, as espécies que compõem o grupo fraterculus atualmente, e que ocorreram naquele levantamento, estavam distribuídas em três diferentes grupos.

Zucchi (1977), com base em características morfológicas do acúleo, asas e cabeça, caracterizou um grupo de 17 espécies próximas a $A$. fraterculus enquadrando-as no "complexo fraterculus". Morgante et al. (1980), em um estudo isozímico do gênero Anastrepha, propuseram a denominação "grupo fraterculus" para o grupo de 17 espécies alistadas por Zucchi (1977) e, com base em características genéticas, também incluíram A. ludens nesse grupo. Norrbom \& Kim (1988) consideraram 27 espécies como pertencentes ao grupo fraterculus, sem explicar as bases para essa classificação.

Atualmente, o grupo fraterculus é composto por 29 espécies (Norrbom et al., 1999), das quais 17 ocorrem no Brasil: A. amita Zucchi, 1979, A. antunesi Lima, 1938, A. bahiensis Lima, 1937, A. barbiellinii Lima, 1938, A. coronilli Carrejo \& González, 1993 A. distincta Greene, 1934, A. fischeri Lima, 1934, A. fraterculus (Wied., 1830), A. martetela Zucchi, 1979, A. minensis Lima, 1937 A. obliqua (Macquart, 1835), A. perdita Stone, 1942, A. quiinae Lima, 1937, A. sororcula Zucchi, 1979, A. tenella Zucchi, 1979, A. turpiniae Stone, 1942 e A. zenildae Zucchi, 1979. Outras espécies do grupo fraterculus não assinaladas no Brasil são: A. ampliata Hernández, 1990, A. canalis Stone, 1942, A. compressa Stone, 1942, A. irradiata Blanchard, 1961, A. irretita Stone, 1942, A. ludens (Loew,1873), A. macra Stone, 1942, A. reichardti Zucchi, 1979, A. schultzi Blanchard, 1938, A. suspensa (Loew, 1862), A. turicai Blanchard, 1961 e A. zuelaniae Stone, 1942 (Norrbom et al., 1999). Baseados em dados moleculares, 
McPheron et al. (1999) consideraram A. acris Stone, que não ocorre no Brasil e estava colocada entre as espécies sem grupo definido, como pertencente ao grupo fraterculus.

Caracteres taxonômicos sutis distinguem as espécies desse grupo. $A$. sororcula e $A$. fraterculus, por exemplo, apresentam no ápice do acúleo uma distinta constrição e menos de 15 dentes. No entanto, o ápice de $A$. fraterculus é mais longo do que o de $A$. sororcula (Zucchi, 1999a).

A. fraterculus, A. obliqua e $A$. sororcula são as espécies de maior importância econômica no Brasil, infestando principalmente frutos da família Myrtaceae (A. fraterculus e A. sororcula) e Anacardiaceae (A. obliqua) (Malavasi et al., 1980). Além destas, $A$. zenildae pode causar perdas significativas em algumas regiões do Brasil (Canal D. \& Zucchi, 1998). A. fraterculus é a espécie mais polífaga do gênero, atacando mais de 80 hospedeiros (Norrbom \& Kim, 1988) e tem sido objeto de vários estudos devido à sua grande importância econômica e também por representar um dos problemas taxonômicos mais difíceis dentro do gênero (Aluja, 1994).

\subsection{Complexo fraterculus}

Um grande volume de estudos tem evidenciado a heterogeneidade morfológica, biológica e genética da espécie nominal $A$. fraterculus ao longo da sua distribuição geográfica (Stone, 1942; Bush, 1962; Morgante et al., 1980; Malavasi \& Morgante, 1982; Steck, 1991; Steck \& Sheppard, 1993; Santos, 1994; Amaral, 1994; Selivon, 1996 e Santos, 1999).

Stone (1942) discutiu a variação morfológica, principalmente do padrão alar, existente em A. fraterculus. Segundo aquele autor, o padrão alar seria característico de cada região. Muitos espécimens brasileiros, estudados por ele, apresentavam as faixas costal e em $\mathrm{S}$ separadas e a faixa em $\mathrm{V}$ incompleta. Espécimens procedentes do norte da América Central apresentavam as faixas em $\mathrm{S}$ e em $\mathrm{V}$ unidas. Não detectou variações no acúleo, apesar da variação no padrão alar, e considerou as várias formas como raças geográficas, afirmando que "como tratada aqui, esta espécie estende-se do Rio Grande 
no sul do Texas até o sul da Argentina e é possível que será finalmente verificado que representa um complexo de espécies ao invés de uma espécie única". Afirmou também que "é provável que várias outras espécies serão encontradas no complexo e que estudos biológicos adicionais demandarão uma alteração dos conceitos aqui descritos".

Baker et al. (1944) descreveram diferenças no padrão alar e no acúleo de espécimens de $A$. fraterculus provenientes do México e da América do Sul, e consideraram a "forma mexicana" distinta da sul-americana.

Bush (1962) relatou diferenças entre os cariótipos de A. fraterculus provenientes do México e de duas populações do Estado de São Paulo descritas por Mendes (1958). Essas diferenças levaram-no a concluir que se tratava de um caso de polimorfismo cromossômico ou, mais provavelmente, de ocorrência de espécies crípticas. Segundo Bush (1962), a hipótese de espécies crípticas seria corroborada também pelas diferenças morfológicas sutis, mas consistentes, existentes nos adultos e pela diferença quanto à preferência de hospedeiros exibida pelas populações mexicana $\mathrm{e}$ brasileira.

Hernández-Ortiz et al. (1999) traçaram comparações morfológicas entre populações mexicanas e sul-americanas de $A$. fraterculus e concluíram que as populações mexicanas são morfologicamente menos variáveis que as demais.

As relações filogenéticas no gênero Anastrepha foram estudadas por Morgante et al. (1980) através do uso de eletroforese de isozimas, onde analisaram 11 locos enzimáticos para 15 espécies em um total de 16 populações de $A$. fraterculus de várias localidades do Brasil. Os resultados mostraram a presença de pelo menos quatro táxons distintos entre as populações de $A$. fraterculus analisadas, assim como heterogeneidade genética intra e interpopulacional. Os táxons foram agrupados em: grupo A - populações de São Paulo, Bahia, Sergipe e Pernambuco; grupo B - uma população de São Paulo; grupo C - duas populações da Bahia e grupo D - populações de São Paulo, Rio de Janeiro e Minas Gerais. Foi observada grande similaridade genética entre populações geograficamente distantes (como São Paulo e Pernambuco) e alta 
diferenciação genética em populações simpátricas provenientes de hospedeiros diferentes. Com base nesses resultados, os autores propuseram o termo "complexo fraterculus" para definir as espécies crípticas existentes sob a espécie nominal $A$. fraterculus, ou seja, populações morfologicamente indistinguíveis, mas com considerável heterogeneidade genética. Entende-se por espécie nominal, um conjunto de populações, que na realidade corresponde a um conjunto de espécies biológicas. Esse estudo sugeriu também que algumas das espécies desse gênero são relativamente jovens e que a especiação tem sido rápida e recente.

Um estudo cariotípico em populações brasileiras de $A$. fraterculus, baseado na morfologia do cromossomo sexual, mostrou a existência de quatro cariótipos, dois presentes no Estado de São Paulo e dois no Estado da Bahia (Solferini \& Morgante, 1987). Os cariótipos denominados 3 e 4 ocorreram isoladamente e foram considerados espécies crípticas. Morgante et al. (1993) verificaram posteriormente que um dos cariótipos descritos para a Bahia (cariótipo 3), que mostrava um comportamento distinto, pertencia, na verdade, à $A$. sororcula. Basso \& Manso (1998) descreveram polimorfismo cromossômico entre populações de $A$. fraterculus na Argentina e a presença de variantes cromossômicas brasileiros em meio a essas populações.

Malavasi \& Morgante (1980), através de eletrofose de isozimas, estudaram 10 espécies de Anastrepha, com ênfase na espécie nominal $A$. fraterculus, para a qual analisaram cinco populações. Observaram níveis diferentes de variabilidade, sendo esta (medida pelo número de locos polimórficos e heterozigosidade) considerada baixa, mesmo comparando-se Anastrepha a outros insetos. Os autores sugeriram que a redução do tamanho da população (com conseqüente perda de alelos), que depende da disponibilidade de hospedeiros, pode ser responsável por essa situação.

Posteriormente, Malavasi \& Morgante (1983) analisaram populações de $A$. fraterculus provenientes de vários hospedeiros em um mesmo pomar, na tentativa de correlacionar variabilidade genética a hospedeiros. Entretanto, a variabilidade genética encontrada foi baixa, assim como os valores de heterozigosidade, concluíram não haver 
correlação entre diferenciação genética e hospedeiros. Aspectos como polifagia, multivoltinismo e mudanças sazonais no tamanho das populações, em função da disponibilidade de hospedeiros, foram discutidos na tentativa de explicar a baixa variabilidade genética.

Steck (1991) conduziu uma análise isozímica em oito populações de $A$. fraterculus provenientes das Américas Central e do Sul, além de populações de $A$. distincta, $A$. obliqua e $A$. striata. Os resultados indicaram a similaridade entre populações do nordeste do Brasil, região costeira da Venezuela, Costa Rica e México, distinguindo-as de populações do sudeste do Brasil, dos Andes venezuelanos e do Peru. A diferença alélica entre as populações da Venezuela, geograficamente próximas, mas com altitude e clima diferentes, levaram aquele autor a concluir que pouco ou nenhum fluxo gênico ocorria entre aquelas populações. Entretanto, as populações de $A$. striata mostraram um único loco variante; para $A$. obliqua e $A$. distincta nenhum loco pôde ser utilizado para distinguir essas populações. $\mathrm{O}$ autor sugeriu a existência de um complexo de espécies crípticas dentro da espécie nominal $A$. fraterculus, questionando a origem monofilética desse complexo.

Steck \& Sheppard (1993) analisaram o DNA mitocondrial (DNAmt) para duas populações de $A$. fraterculus do Brasil e duas da Venezuela, através de enzimas de restrição (gerando padrões de fragmentos obtidos por digestão por enzimas de restrição - RFLP). Os resultados desse trabalho corroboraram alguns dos resultados conseguidos por Steck (1991): (1) a diferenciação entre as populações venezuelanas (de baixa e elevada altitude) com ausência de fluxo gênico; e (2) a diferenciação entre as populações brasileiras (Sudeste e Nordeste). Diferiu, entretanto, quanto à semelhança genética descrita pela análise isozímica entre a população costeira da Venezuela e as populações da Bahia. Pela análise com enzimas de restrição essas populações são bastante distintas.

A variabilidade do DNAmt para 11 populações brasileiras de $A$. fraterculus, duas de A. obliqua e duas de A. sororcula foi caracterizada por Santos (1994). As análises de RFLP com 10 enzimas de restrição resultaram em 21 sítios polimórficos e 21 
haplótipos que ocorreram em dois grupos distintos denominados grupo I e grupo II, sendo o I mais polimórfico que o II. A ocorrência desses grupos não correspondeu aos limites das espécies, já que as populações de $A$. fraterculus apresentaram os dois grupos de haplótipos enquanto as populações de $A$. obliqua e $A$. sororcula apresentam apenas o grupo II de haplótipos. Uma das hipóteses para a presença dos dois grupos de haplótipos em $A$. fraterculus seria a de que cada grupo de haplótipo pertenceria a uma espécie distinta, descartando a origem monofilética do grupo.

Essas mesmas amostras foram utilizadas na análise do DNA ribossomal (DNAr) através de enzimas de restrição. Nesse caso, cada espécie estudada ( $A$. fraterculus, A. obliqua e $A$. sororcula) apresentou um conjunto único de marcadores, sendo que mesmo as populações de $A$. fraterculus nas quais os dois grupos de haplótipos mitocondriais ocorreram concomitantemente, todos os indivíduos apresentaram o mesmo padrão de restrição para o DNAr. Diferentemente do padrão de restrição para o DNAmt, o DNAr apresentou um padrão de variabilidade cujos resultados estão de acordo com a classificação taxonômica baseada em caracteres morfológicos para essas espécies (Santos, 1999).

Amaral (1994) aplicou a técnica de eletroforese de isozimas para estudar a variabilidade genética de 10 populações de $A$. fraterculus, utilizando as larvas, para as quais foram analisadas sete enzimas. Apesar da heterozigosidade encontrada ter sido baixa, as populações do sudeste do Brasil mostraram-se geneticamente distintas das populações do nordeste. Ou seja, os resultados são congruentes com aqueles conseguidos por Steck (1991) e Steck \& Sheppard (1993).

Estudos isozímicos, cariotípicos, morfométricos e de cruzamentos foram conduzidos por Selivon (1996) em populações da espécie nominal A. fraterculus. Foram reconhecidos dois grupos (I e II) entre as populações analisadas, as quais puderam ser distinguidas em todos os níveis estudados, ou seja, diferenças nas freqüências alélicas de determinados locos, nos valores de similaridade e distância genética, F-estatístico e diferenças cromossômicas, além de um certo grau de isolamento reprodutivo e 
diferenças morfológicas. Com base nessas diferenças foi proposto o reconhecimento da existência de dois táxons distintos, denominados $A$. fraterculus tipo I e $A$. fraterculus tipo II. Posteriormente, Selivon \& Perondini (1998) descreveram a morfologia externa dos ovos de A. fraterculus descritos como tipo I e II. Apesar da semelhança na forma, os ovos das duas espécies diferiram no comprimento e em características da parte anterior do ovo, tais como presença ou ausência de papilas e localização da micrópila.

A análise morfométrica também foi empregada por Araujo (1997) no estudo de cinco espécies do grupo fraterculus: A. fraterculus, A. obliqua, A. sororcula, $A$. zenildae e $A$. turpiniae. A análise morfométrica comprovou as identificações baseadas nas variações morfológicas do acúleo, como comprimento e características do ápice. Considerando-se a espécie nominal $A$. fraterculus, constatou-se que o comprimento médio do acúleo foi decisivo no agrupamento das populações e que a proximidade geográfica parece não interferir nesse processo.

\subsection{Variabilidade genética}

Segundo Ehrlich \& Raven (1969), as populações de praticamente todas as espécies exibem algum grau de variação genética entre diferentes localidades geográficas. As variações geográficas, por sua vez, são geradas e mantidas por processos evolutivos locais influenciados por mecanismos genéticos e processos ambientais (Kim, 1993).

Futuyma \& Peterson (1985) citaram a deriva genética, a seleção natural e o fluxo gênico como principais responsáveis pela variabilidade genética entre populações. Segundo-Kim (1993), essa variabilidade pode se expressar em características biológicas como: morfologia, comportamento sexual, taxa de desenvolvimento e fecundidade, capacidade de dispersão, adaptação sazonal (diapausa), preferência alimentar e por hospedeiros e resistência a pesticidas e outras toxinas. Ao nível cromossômico, a diversidade pode se expressar em polimorfismo alozímico e divergência nas seqüências de DNA. 


\subsection{DNA mitocondrial ( DNAmt)}

O DNAmt de animais multicelulares apresenta características que o tornam útil no estudo da evolução molecular: pequeno tamanho, a natureza haplóide e a herança predominantemente materna que elimina as variações que sejam de natureza biparental (Brown, 1983). A origem materna e o alto grau de polimorfismo fazem dessa molécula um importante instrumento na análise de populações (Avise \& Lansman, 1983).

Com poucas exceções, o DNAmt animal é uma molécula circular fechada, cujo tamanho varia de 15,7 a 19,5 kilobases (kb) (Brown, 1983). É composto de cerca de 37 genes, sendo que 22 genes codificam para RNAs transportadores, 2 genes codificam para RNAs ribossômicos e 13 genes codificam para proteínas envolvidas no transporte de elétrons e na fosforilação oxidativa (Avise, 1994; Harrison, 1989).

Em geral, a replicação no DNAmt é unidirecional, altamente assimétrica (Attardi, 1985) e controlada por uma região conhecida como região rica em $\mathrm{A}+\mathrm{T}$ (adenina e timina) em insetos (Fauron \& Wolstenholme, 1980) ou "D-loop" (“displacement loop") em vertebrados (Clary \& Wolstenholme, 1987; Zhang et al., 1995) .

O DNA mitocondrial tem sido intensamente estudado, pois é facilmente isolado e purificado quando comparado ao DNA nuclear; tem maior densidade; tem um grande número de cópias na célula e está localizado dentro da organela (Hoy, 1994).

Essa molécula apresenta poucas variações de tamanho, que estariam principalmente relacionadas à região controle. A presença de regiões intergênicas (RIG) no DNAmt de animais tem sido considerada rara, e quando presente, apresenta pequeno tamanho (Moritz et al., 1987). Uma região intergênica entre o tRNA $A^{\text {Lẹ }}$ e a subunidade II do gene citocromo oxidase foi reportada em Apis (Cornuet \& Garnery, 1991; Cornuet et al., 1991; Garnery et al., 1993; De La Rua et al., 1998) e também em tefritídeos do gênero Rhagoletis (Smith \& Bush, 1997). 
Dentre os genes que compõem o DNAmt, os genes citocromo oxidase I (COI) e citocromo oxidase II (COII) têm sido utilizados para inferir relações filogenéticas (Sanchis et al., 2000; Smith \& Bush, 1997; Brown et al., 1994; Brower, 1994; Garnery et al., 1991; Crozier et al., 1989), investigar processos de especiação (Morrow et al., 2000), auxiliar na identificação de espécies (Brown et al., 1999) e estudar a estrutura de populações (Scarpassa et al., 2000; Cornuet \& Garnery, 1991).

Em tefritídeos, especificamente, o gene COII mostrou-se variável no estudo da filogenia do gênero Rhagoletis, revelando que as espécies presentes na América do Norte têm origem monofilética (Smith \& Bush, 1997). Em trabalho posterior, Smith \& Bush (1999) compararam os resultados gerados pela análise do COII com dados morfológicos disponíveis para a tribo Carpomyina, com ênfase no gênero Rhagoletis, incluindo espécies neárticas e paleárticas. Os resultados indicaram que a taxa de evolução de caracteres morfológicos e moleculares parece ser diferente. Para Rhagoletis as taxas de divergência morfológica têm sido baixas apesar da considerável divergência no DNA.

Para as espécies simpátricas, B. tryoni (Froggatt, 1897) e B. neohumeralis (Hardy, 1951), a análise conjunta de genes, entre eles o COII, pôde comprovar a similaridade genética entre as espécies, mesmo sendo possível distingui-las por caracteres morfológicos (Morrow et al., 2000).

O gene mitocondrial de RNA ribossômico $16 \mathrm{~S}$ e o gene nuclear de RNA ribossômico $18 \mathrm{~S}$ também se mostraram úteis nos estudos evolutivos de insetos, especialmente tetritídeos. Han \& McPheron (1994) utilizaram o gene 18S em um estudo que envolveu 26 espécies de tefridídeos e outras quatro espécies pertencentes a diferentes famílias de Tephritoidea. A análise desse gene permitiu aos autores sugerir a monofilia da subfamília Tephritinae.

Han \& McPheron (1997) também trabalharam com o gene 16S, analisando 34 espécies que representaram 12 táxons supragenéricos e 28 gêneros de tefritídeos. $\mathrm{O}$ principal objetivo do estudo foi investigar a possibilidade de utilização desse gene, nos 
diferentes níveis taxonômicos, em estudos filogenéticos de tefritídeos. Em conclusão, o gene 16S pôde auxiliar na compreensão da história evolutiva do grupo fraterculus e das relações filogenéticas entre as linhagens de tefritídeos.

De fato, McPheron et al. (1999) utilizaram esse mesmo gene (16S) no estudo das relações filogenéticas entre 14 grupos de espécies do gênero Anastrepha, três espécies de Toxotrypana e duas de Hexachaeta. Nesse caso, algumas das relações entre grupos de espécies definidas com base na morfologia, inclusive dentro do grupo fraterculus, foram corroboradas pelos dados moleculares.

Silva (2000) revisou as possibilidades do uso de diferentes marcadores moleculares em estudos realizados com diferentes gêneros de tefritídeos.

As taxas de mutação, que geram polimorfismo no DNAmt, são variáveis para os diferentes genes e podem ocasionar diferentes níveis de divergência (Brown, 1983; Avise, 1994). Algumas vezes, o polimorfismo pode ser maior entre espécies correlatas do que entre organismos geneticamente distantes (Brown, 1983, Harrison, 1989). Fauron \& Wolstenholme (1980) analisaram em Drosophila melanogaster Meigen, 1830, D. simulans, Sturtevant, 1919 e D. mauritiana Tsacas \& David, 1974, a variação de tamanho do DNAmt reportada em 700 pares de base (pb).

Os trabalhos clássicos, que analisaram as variações do DNAmt, basearam-se em comparações de padrões de fragmentos obtidos por digestão por enzimas de restrição e mapas de restrição gerados por digestões múltiplas (Lansman et al., 1981; Harrison, 1989). Entretanto, com o advento de técnicas moleculares de maior poder de resolução, como seqüenciamento direto do DNA, a variabilidade genética dos organismos pode ser melhor compreendida (Wilson et al., 1985; Moritz et al., 1987). 


\section{METODOLOGIA}

\subsection{As amostras}

Foram estudados exemplares de Anastrepha pertencentes ao grupo fraterculus, provenientes de diferentes localidades nas Américas do Sul, Central e do Norte. Nas Tabelas 1, 2 e 3 estão alistadas as espécies analisadas via PCR e seguidas de seqüenciamento direto, para os genes COI, ND6 e parte do gene 16S, respectivamente. $\mathrm{Na}$ Tabela 4, estão as informações das amostras da espécie nominal A. fraterculus estudadas através de enzima de restrição.

Foram analisadas amostras depositadas na coleção da Escola Superior de Agricultura "Luiz de Queiroz" (ESALQ), que haviam sido estudadas em teses e dissertações conduzidas no setor de Entomologia da ESALQ. Foram analisadas também outras amostras, incluindo uma de $A$. fraterculus, proveniente de Chapecó, SC, que apresentava exemplares com os dentes do acúleo malformados.

As amostras provenientes do México, Venezuela, Costa Rica e Guatemala são as mesmas utilizadas por Steck (1991) em sua análise isozímica. Os espécimens testemunha dessas amostras estão depositados no National Museum of Natural History, Smithsonian Institution, Washington, D.C., EUA.

O nome dos países está abreviado conforme nomenclatura internacional, sendo: Argentina, ARG; Brasil, BRA; Colômbia, COL; Costa Rica, CRA; Guatemala, GUA; México, MEX; Trinidad Tobago, TOB e Venezuela, VEN. 


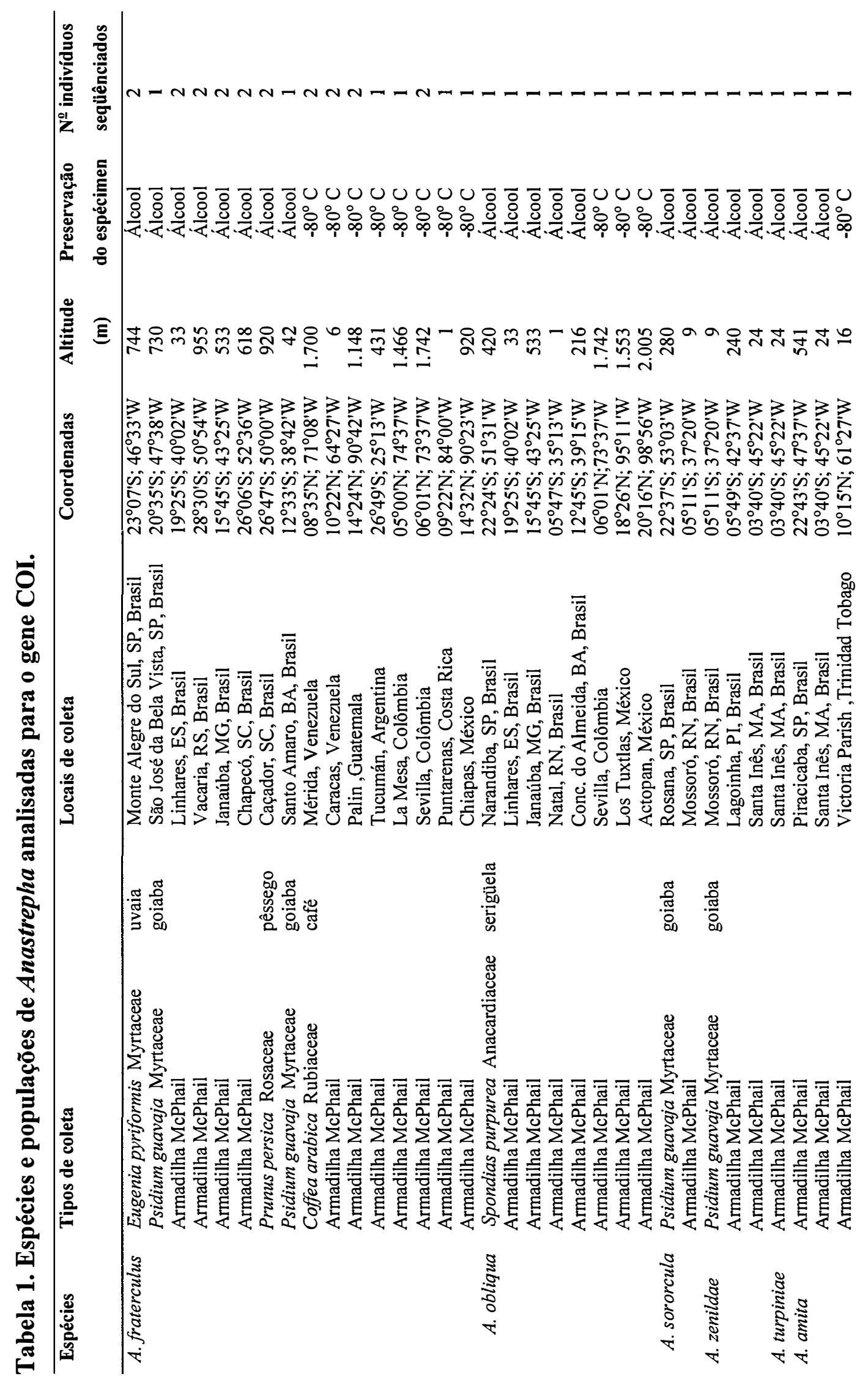




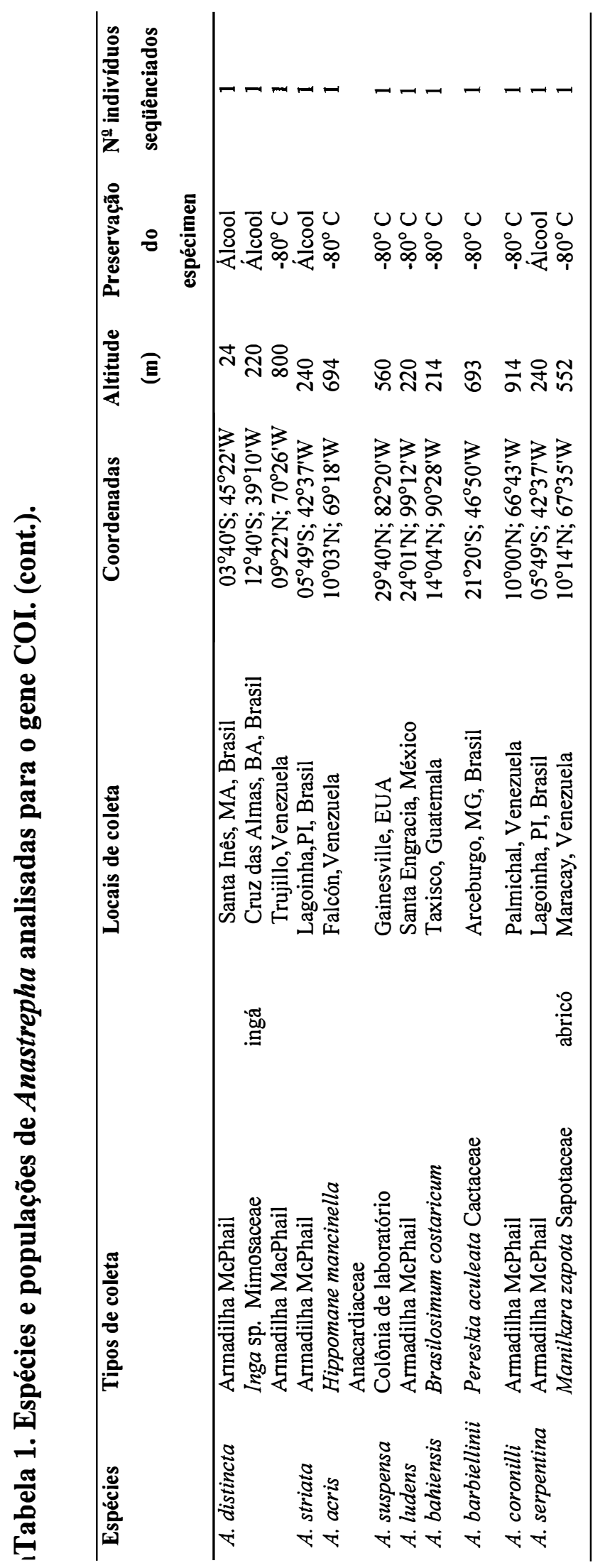




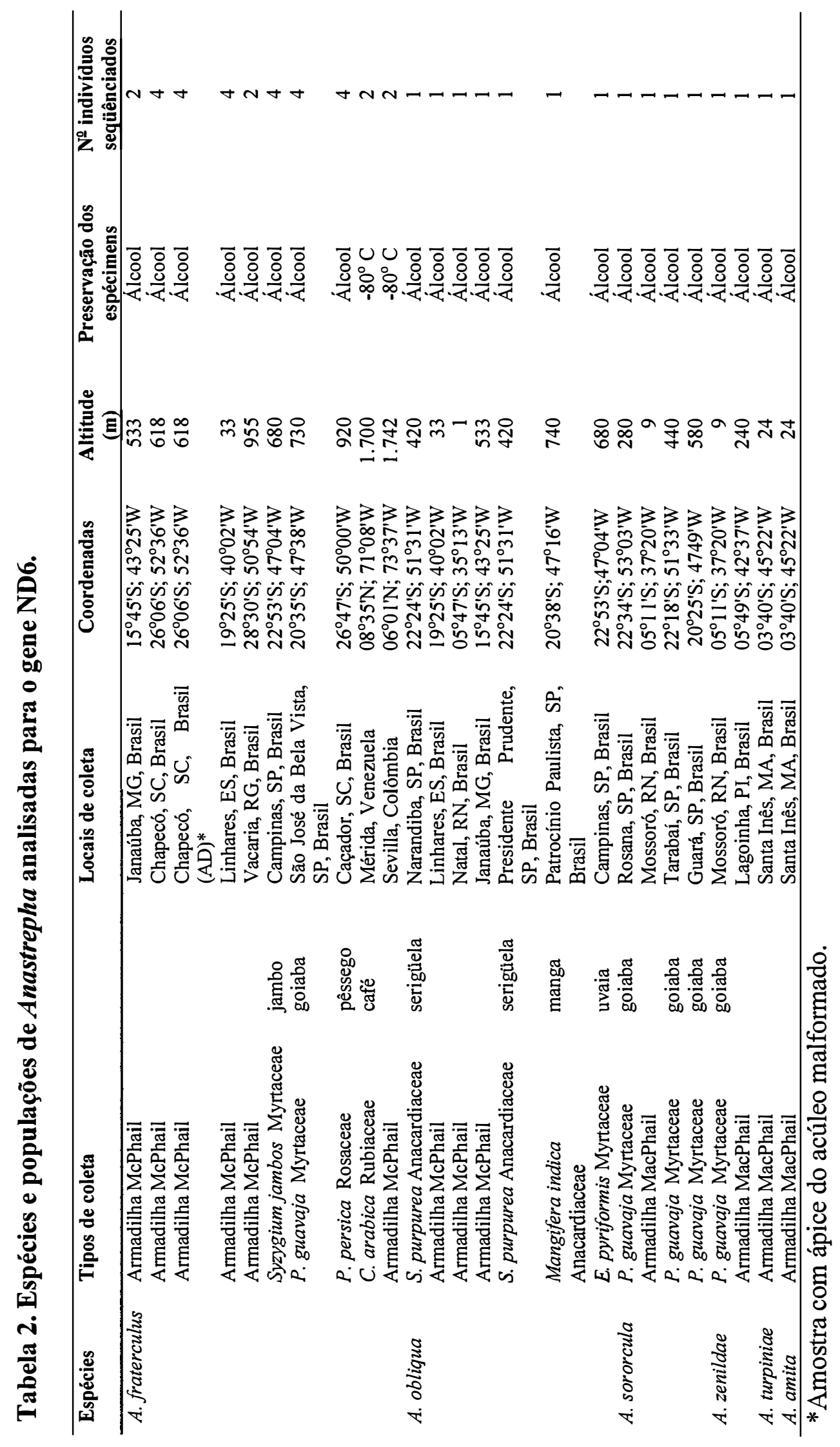




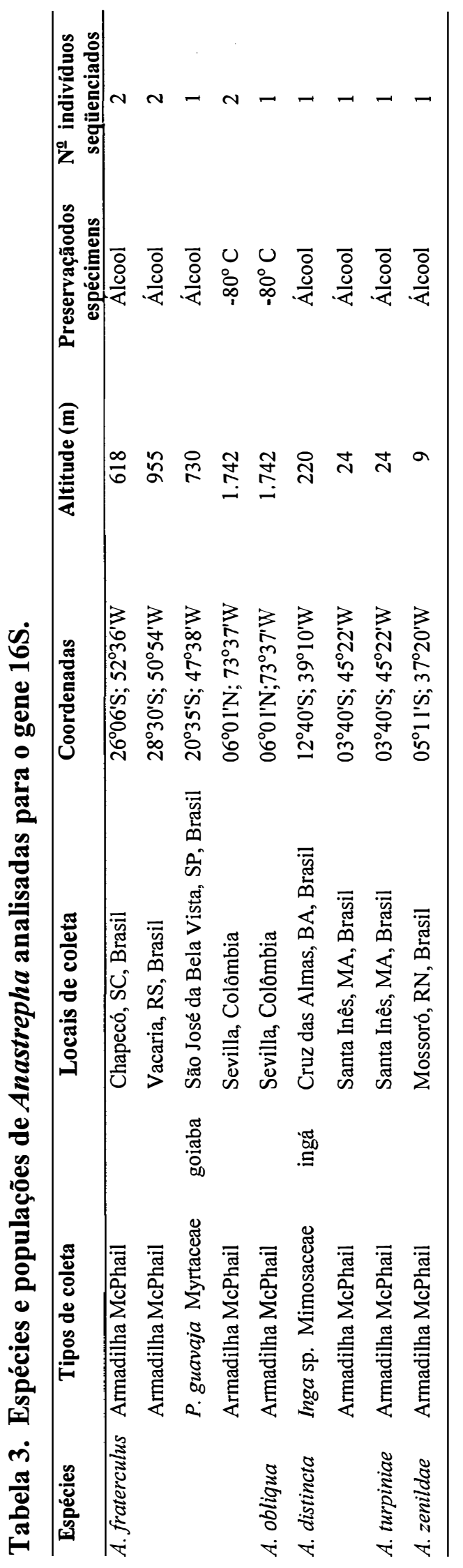




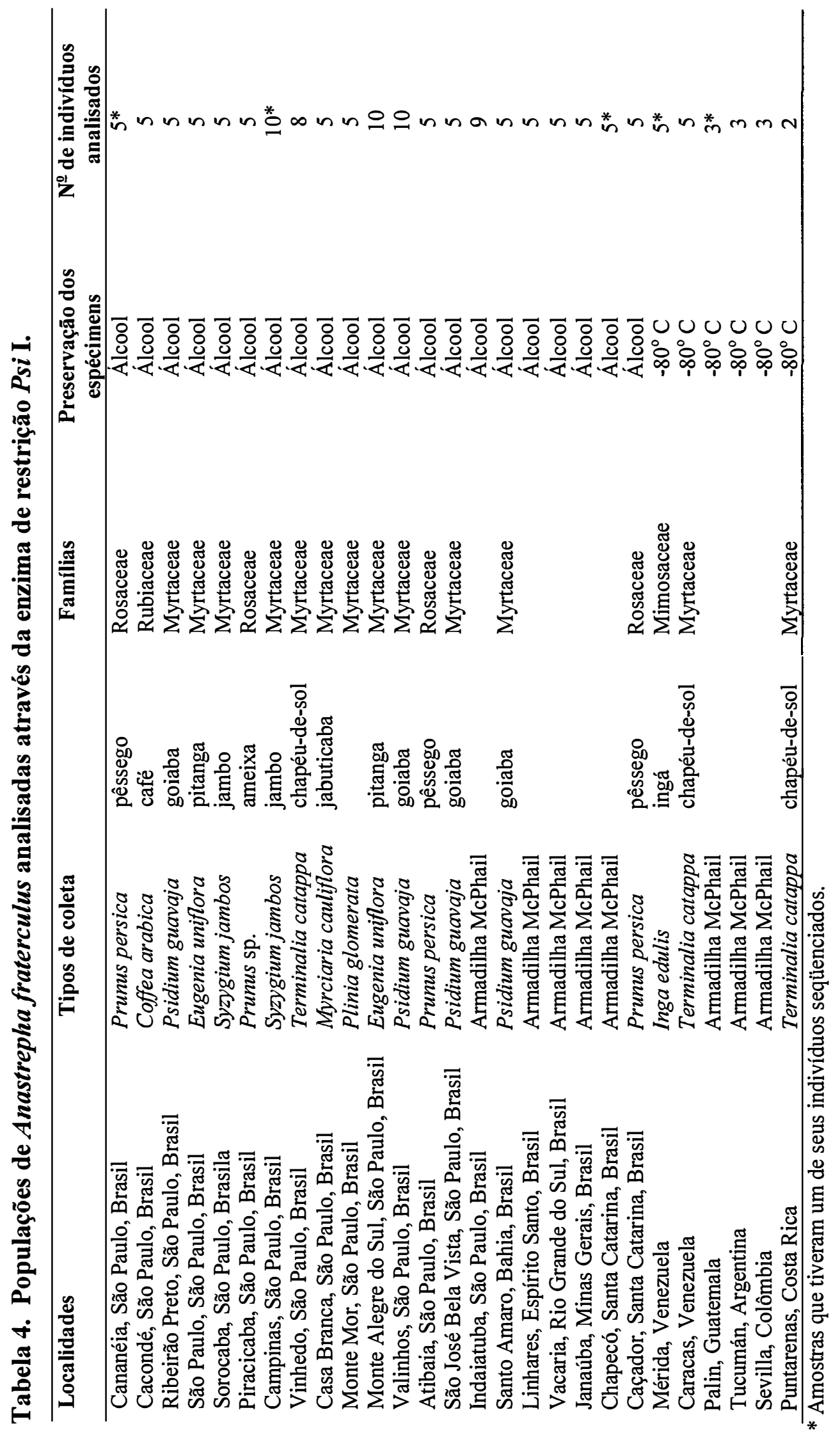




\subsection{Regiões do DNA mitocondrial estudadas}

As regiões do DNAmt analisadas correspondem a partes dos genes COI, ND6 e a região compreendida entre os genes COI e COII, além de parte da subunidade 16S do rRNA (Figura 1).

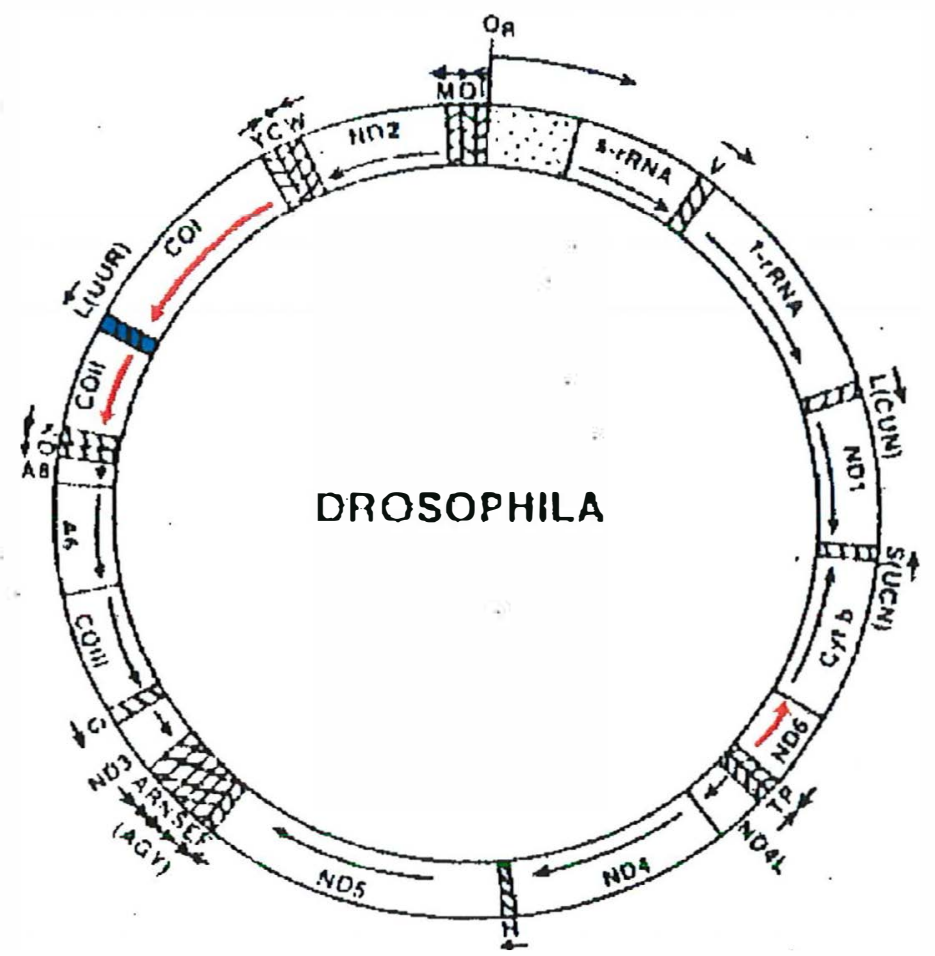

Figura 1. Mapa circular do DNAmt de Drosophila yakuba mostrando a localização e direção da transcrição dos genes. Os genes COI, COII e ND6 utilizados nesse estudo, aparecem em destaque em vermelho. $O$ tRNA ${ }^{\text {Leu }}$ aparece em azul.

Fonte: Modificado de Simon et al., (1994).

\subsection{Extração de DNA total}

As extrações de DNA total de cada exemplar foram feitas seguindo o protocolo descrito por Han \& McPheron (1997) para espécimens alfinetados ou 
preservados em álcool. No Apêndice estão as descrições completas do protocolo e do preparo das soluções utilizadas.

\subsection{Reação da polimerase em cadeia (PCR)}

Para cada amostra, foram colocados $15,75 \mu \mathrm{L}$ da solução A, que consiste de 1X tampão de reação Qiagen ${ }^{\circledR}, 250 \mu \mathrm{M}$ de cada um dos di-nucleotídeos tri-fostato (A,

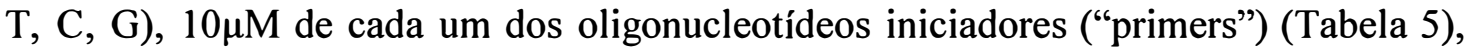
cloreto de magnésio $25 \mathrm{mM}$ e água-milliQ estéril. A cada um dos tubos Eppendorf foi adicionada em uma conta de parafina AmpliWax ${ }^{\mathrm{TM}}$ PCR Gem 50, Perkin Elmer, e os tubos foram incubados a $80^{\circ} \mathrm{C}$ por 5 minutos. Após esse período, $32,25 \mu \mathrm{L}$ da solução $\mathrm{B}$, consistindo de 1X tampão de reação Qiagen, 0,25 unidades de Qiagen ${ }^{\circ}$ Taq polimerase e água-milliQ estéril, foram adicionados a cada tubo. Dois $\mu \mathrm{L}$ de DNA total extraído foram usados nessa reação, cujo volume final foi de $50 \mu \mathrm{L}$. Os programas utilizados no termociclador (Techne Genius e Gene Amp PCR System 9700, Perkin Elmer) para cada par de "primers" estão descritos na Tabela 6.

Para cada reação de amplificação foram corridos géis de agarose a 1\%, corados com brometo de etídeo $(5 \mu \mathrm{g} / \mathrm{mL})$, com tampão TBE $0,5 X$ preparado de acordo com Sambrook et al. (1989). As amostras foram preparadas utilizando-se $4 \mu \mathrm{L}$ de produto de PCR, $2 \mu \mathrm{L}$ de uma solução de azul de bromofenol $0,25 \%$, xileno cianol $0,25 \%$, sacarose $40 \%$ e $4 \mu \mathrm{L}$ de água milli-Q estéril. Como marcador de peso molecular utilizou-se $\phi X 174$ RF digerido com Hae III. Após visualização sob luz UV (cerca de $300 \mathrm{~nm}$ ), os géis foram fotografados com filme Polaroid 667 através de filtro vermelho (Wratten 21 Kodak) ou com câmera digital Kodak Digital Science DC120 Zoom acoplada a um computador equipado com o programa "Kodak Digital Science ${ }^{\mathrm{TM}}$ Electrophoresis Documentation and Analysis System 120". 


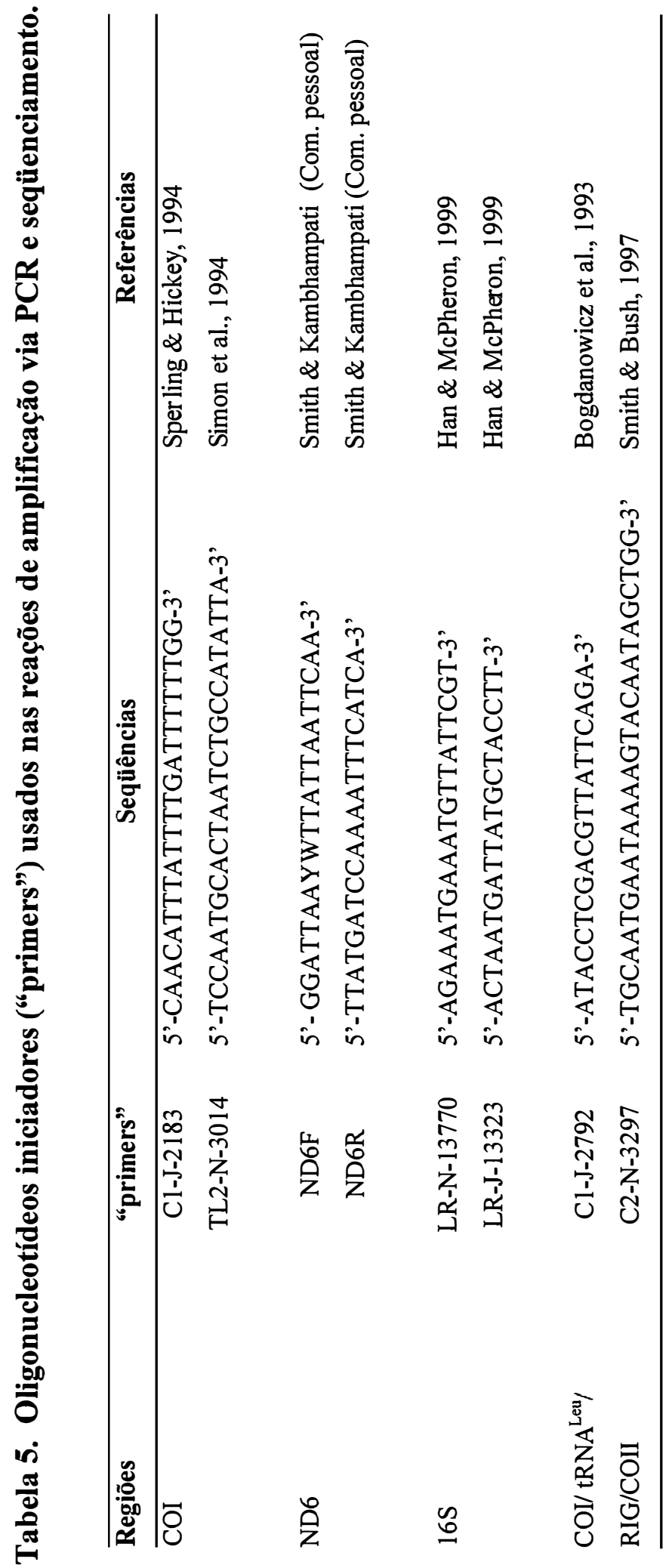


Todos os produtos de PCR foram purificados com o QIAquick PCR Purification Kit da Qiagen ${ }^{\circledR}$ antes de serem submetidos ao seqüenciamento Nos casos de amplificações inespecíficas, o DNA foi gel purificado utilizando-se o QIAquick Gel Extraction Kit da Qiagen ${ }^{\circledR}$ antes do seqüenciamento ou digestão por enzima de restrição. Em ambos os casos seguiu-se rigorosamente as especificações de uso do fabricante.

Tabela 6. Programas de termociclador utilizados para os diferentes pares de "primers".

\begin{tabular}{|c|c|}
\hline "Primers" & Programas \\
\hline Cl-J-2183/TL2-N-3014 & $\begin{array}{l}95^{\circ} \mathrm{C} \text { por } 7 \text { min.; } 35 \text { ciclos }\left(94^{\circ} \mathrm{C} \text { por } 1 \text { min., } 45^{\circ} \mathrm{C} \text { por } 1\right. \\
\left.\min , 65^{\circ} \mathrm{C} \text { por } 8 \mathrm{~min}\right) ; 65^{\circ} \mathrm{C} \text { por } 15 \mathrm{~min}\end{array}$ \\
\hline ND6F/ ND6R & $\begin{array}{l}94^{\circ} \mathrm{C} \text { por } 3 \mathrm{~min} ; 10 \text { ciclos }\left(95^{\circ} \mathrm{C} \text { por } 30 \mathrm{~s}, 43^{\circ} \mathrm{C} \text { por } 30 \mathrm{~s} \text {, }\right. \\
72^{\circ} \mathrm{C} \text { por } 30 \mathrm{~s} ; 28 \text { ciclos }\left(95^{\circ} \mathrm{C} \text { por } 30 \mathrm{~s}, 48^{\circ} \mathrm{C} \text { por } 30 \mathrm{~s} \text {, }\right. \\
72^{\circ} \mathrm{C} \text { por } 30 \mathrm{~s} ; 72^{\circ} \mathrm{C} \text { por } 7 \mathrm{~min}\end{array}$ \\
\hline LR-N-13770/LR-J-13323 & $\begin{array}{l}40 \text { ciclos }\left(93^{\circ} \mathrm{C} \text { por } 1 \mathrm{~min}, 50^{\circ} \mathrm{C} \text { por } 1 \mathrm{~min}, 72^{\circ} \mathrm{C} \text { por } 2\right. \\
\min ) ; 94^{\circ} \mathrm{C} \text { por } 1 \mathrm{~min} ; 50^{\circ} \mathrm{C} \text { por } 1 \mathrm{~min} ; 72^{\circ} \mathrm{C} \text { por } 9 \min \end{array}$ \\
\hline Cl-J-2792/ C2-N-3297 & $\begin{array}{l}95^{\circ} \mathrm{C} \text { por } 7 \mathrm{~min} ; 35 \text { ciclos }\left(94^{\circ} \mathrm{C} \text { por } 1 \mathrm{~min}, 47^{\circ} \mathrm{C} \text { por } 1 \mathrm{~min} \text {, }\right. \\
\left.65^{\circ} \mathrm{C} \text { por } 8 \mathrm{~min}\right) ; 65^{\circ} \mathrm{C} \text { por } 15 \mathrm{~min}\end{array}$ \\
\hline
\end{tabular}

\subsection{Padrões de fragmentos obtidos por digestão por enzimas de restrição (RFLP)}

O DNA amplificado via PCR foi digerido utilizando-se a enzima de restrição Psi I. A decisão quanto ao uso dessa enzima foi tomada com base em dois indivíduos de A. fraterculus, provenientes de Mérida (Venezuela) e Cananéia (Brasil), previamente seqüenciados. Para essas seqüências, foram gerados mapas de restrição para 507 endonucleases através do programa Omiga (Oxford Molecular, 1999), a fim de avaliar a existência de diferentes padrões de restrição nesta região do DNAmt. 
A enzima Psi I, cuja digestão resultou em um número de fragmentos para os quais a resolução em gel de agarose originou um padrão nítido, é proveniente do organismo Pseudomonas species, SibEnzyme Laboratories, que reconhece uma seqüência de seis pares de bases (5'...TTATAA...3' e 3'...AATATT...5').

Pelo menos cinco indivíduos de cada localidade tiveram o DNA digerido e foram comparados entre si. Nos casos em que houve variação intrapopulacional (Campinas, Valinhos e Vinhedo), 10 indivíduos foram analisados.

Os produtos de PCR foram digeridos nas seguintes condições: mistura de reação contendo 1 XSE Buffer e 1 unidade da enzima Psi I; água milli-Q e $1 \mu \mathrm{L}$ de DNA total extraído, em volume final de $20 \mu \mathrm{L}$. As amostras foram incubadas por períodos de 12 a 16 horas a $37^{\circ} \mathrm{C}$. Após esse período adicionou-se $4 \mu \mathrm{L}$ de corante (solução de azul de bromofenol $0,25 \%$, xileno cianol $0,25 \%$ e sacarose $40 \%$ ) para que as amostras pudessem ser corridas no gel. Os produtos de digestão foram separados e visualizados em gel de agarose a $2 \%$, corados com solução de brometo de etídeo $(5 \mu \mathrm{g} / \mathrm{mL})$, utilizando-se as agaroses Biorad e Nusieve na proporção 1:1, com tampão TBE 0,5X preparado de acordo com Sambrook et al. (1989).

Os géis foram observados sob luz UV (cerca de $300 \mathrm{~nm}$ ) para verificar o tamanho dos fragmentos obtidos na digestão e fotografados utilizando-se câmera digital.

Seqüenciou-se 1 indivíduo para cada padrão de restrição encontrado.

\section{6 Seqüienciamento}

Os produtos de PCR foram seqüenciados com os mesmos "primers" utilizados nas reações de amplificação. Ambas as fitas de DNA foram seqüenciadas para evitar ambigüidades.

As seqüências foram processadas na "Nucleic Acid Facility" da Penn State University onde o produto de PCR original foi submetido a um novo PCR, cujo tampão de reação consistiu de dNTPs, corantes ddNTPs, cloreto de magnésio, piro-fosfatase e 
AmpliTAQ DNA polimerase mutante FS. Ao tampão foram adicionados $1 \mu \mathrm{M}$ de cada um dos "primers", 3,0 $\mu \mathrm{L}$ de produto de PCR e água milli-Q estéril.

A reação foi conduzida em termociclador Perkin-Elmer 2400 cujo programa consistiu de: $95^{\circ} \mathrm{C}$ por 3 minutos, 25 ciclos de $96^{\circ} \mathrm{C}$ por 10 segundos, $50^{\circ} \mathrm{C}$ por 5 segundos e $60^{\circ} \mathrm{C}$ por 4 minutos.

Após completada a reação, as amostras foram dessalinizadas em coluna Centriflex e dessecadas através de vácuo por 20 minutos no Savant Speed/Vac System. A ressuspensão deu-se em tampão de formamida deionizada, EDTA $25 \mathrm{mM}$ (pH 8.0) contendo $50 \mathrm{mg} / \mathrm{mL}$ de azul Dextran, na proporção 5:1. As amostras foram corridas em gel de acrilamida a $4 \%$ e tampão 1 XTBE a $48^{\circ} \mathrm{C}$ por 10 horas no seqüenciador automático Perkin-Elmer ABI 377.

As seqüências geradas para cada gene foram comparadas com o gene correspondente de Drosophila yakuba disponível no GenBank (Clary \& Wolstenholme, 1985). Somente os pares de base que mostraram total sobreposição, após o alinhamento, foram considerados nas análises. $\mathrm{O}$ alinhamento das seqüências foi conduzido utilizando-se o programa Omiga (Oxford Molecular, 1999).

\subsection{Análise filogenética}

As análises das relações filogenéticas foram conduzidas utilizando-se os métodos do vizinho mais próximo (NJ, “neighbor-joining”) e máxima parcimônia (MP).

Após análise individual dos genes COI e ND6, analisou-se em conjunto os genes COI + ND6 e COI + 16S. As amostras analisadas para o gene $16 \mathrm{~S}$ e que não constam na Tabela 3 fazem parte dos dados gerados por McPheron et al (1999), tendo sido utilizadas apenas parte das seqüências. 
As amostras de $A$. serpentina e $A$. striata, pertencentes respectivamente aos grupos serpentina e striata, foram analisadas como grupo externo e pelo menos uma delas está presente em cada uma das análises.

Para as análises do NJ, foi utilizado o Programa PAUP* ("Phylogenetic Analysis using Parsimony), versão 4.0bl (Swofford, 1998), e as árvores foram geradas utilizando-se a distância genética de Jukes-Cantor, para a qual também se calculou uma matriz de distância genética.

As análises de MP foram conduzidas utilizando-se o Programa PAUP*, versão 4.0bl (Swofford, 1998), através de busca heurística, para encontrar a mais parcimoniosa das árvores. Os caracteres parcimoniosos foram tratados como tendo igual peso na análise e com a adição ao acaso das seqüências. Nos casos em que mais de uma árvore foi gerada, optou-se por estabelecer o consenso estrito das árvores.

Um "bootstrap" (Fenselstein, 1985) de 100 replicações foi utilizado para estimar o valor das topologias para NJ e MP. Somente foram considerados valores de "bootstrap" superiores a 50. 


\section{RESULTADOS}

\subsection{Relações filogenéticas entre espécies do grupo fraterculus}

\subsubsection{Gene COI}

Para todos os espécimens seqüenciados, um total de 808 pares de bases (pb) foram analisados para este gene. A composição média de nucleotídeos dos 44 indivíduos analisados foi $32,8 \%$ de $\mathrm{A}, 16,2 \%$ de $\mathrm{C}, 13,7 \%$ de $\mathrm{G}$ e $37,3 \%$ de T. A média da distância genética de Jukes-Cantor analisada foi $0,033 \pm 0,0006$, tendo o nível de divergência de seqüência variado de 0 a 0,083 .

A Figura 2 apresenta o filograma gerado a partir do método NJ, utilizando a distância genética de Jukes-Cantor, para as espécies do grupo fraterculus. Os valores de "bootstrap" superiores a 50\% estão representados acima dos ramos apropriados. As árvores geradas pelos métodos de NJ e MP apresentaram topologia semelhante, ainda que a posição relativa de algumas espécies não tenha sido idêntica.

Para as análises de MP , duas árvores foram geradas e o consenso estrito está apresentado na Figura 3. Dos 808 caracteres usados nas análises, 188 foram variáveis e 110 foram variáveis informativos sob parcimônia.

Os resultados mostram que as populações de $A$. amita se agruparam com $A$. turpiniae. As populações de $A$. zenildae formam um agrupamento do qual também faz parte a amostra de $A$. fraterculus de Caracas (VEN), que apresenta maior proximidade genética com a amostra de $A$. zenildae de Santa Inês (MA). 
As amostras de A. obliqua formaram dois agrupamentos distintos. Em um dos agrupamentos, aparecem somente amostras dessa espécie provenientes das localidades de Conceição do Almeida, BA, Sevilla, COL, Los Tuxtlas e Actopan, MEX. O outro agrupamento reúne amostras de $A$. fraterculus e $A$. sororcula, além de $A$. obliqua.

A análise de $\mathrm{NJ}$ para as amostras de $A$. distincta mostrou as populações de Trujillo (VEN) e Cruz das Almas (BA) agrupadas com suporte estatístico moderado, enquanto a população de Santa Inês permaneceu à parte, não pertencendo ao mesmo agrupamento.

Para $A$. fraterculus, este estudo foi baseado em amostras de 16 localidades. Os resultados mostram a presença dessa espécie tanto ocorrendo em agrupamentos uniformes (A. fraterculus de várias localidades ocorrendo juntas), como ocorrendo entre agrupamentos juntamente com outras espécies. Um exemplo de agrupamento uniforme, e com suporte estatístico forte, foi obtido para as amostras de $A$. fraterculus provenientes de Monte Alegre do Sul (SP), Vacaria (RS), Tucumán (ARG), Caçador (RS) e São José da Bela Vista (SP). É importante observar que as amostras das localidades de La Mesa, Sevilla e Mérida, com altitudes superiores a 1.400 metros, formaram um agrupamento à parte com forte suporte estatístico.

Com exceção de $A$. barbiellinii, as outras espécies do grupo fraterculus para as quais somente um exemplar estava disponível, como A. ludens, A. suspensa, A. bahiensis e $A$. coronilli, encaixaram-se dentro dos limites do grupo, assim como A. acris (espécie sem grupo definido com base em caracteres morfológicos). A. barbiellinii ocorreu entre $A$. striata e as amostras de $A$. serpentina analisadas como grupo externo. 


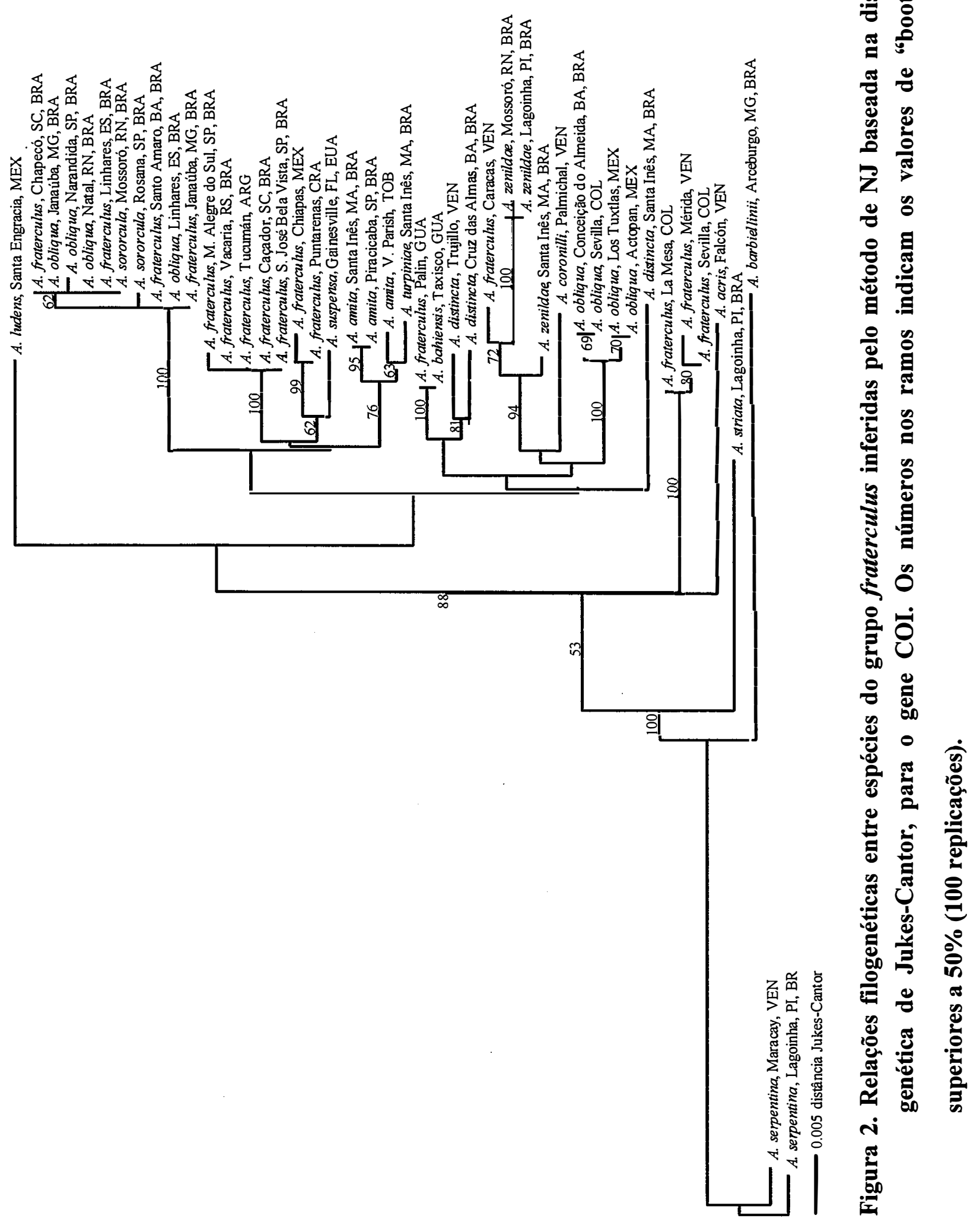




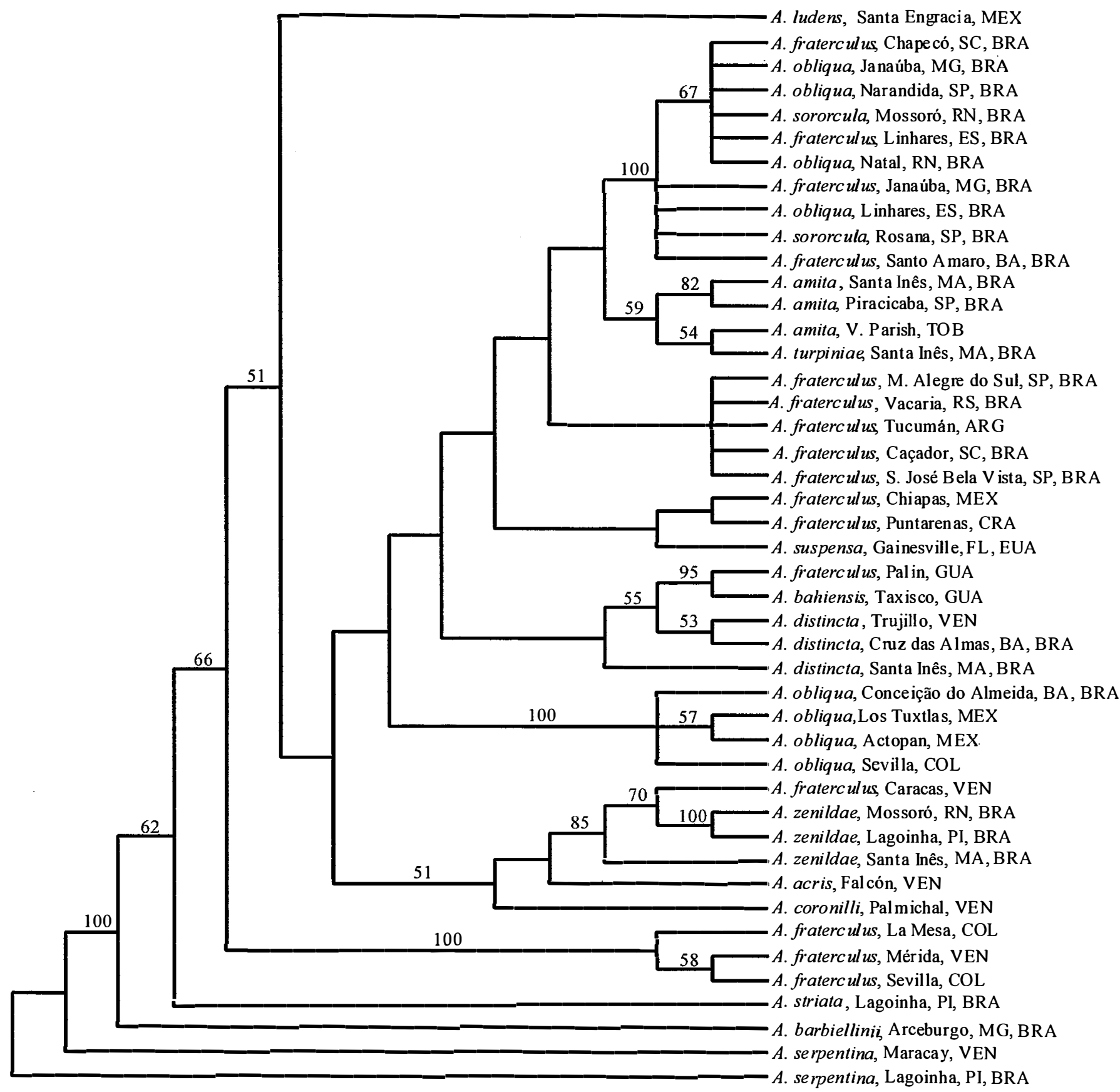

Figura 3 Relações filogenéticas entre espécies do grupo fraterculus inferidas pelo método de MP para o gene COI. Consenso estrito de duas das mais parcimoniosas árvores. Os números nos ramos indicam os valores de "bootstrap" superiores a 50\% (100 replicações). 


\subsubsection{Gene ND6}

$\mathrm{O}$ gene ND6 foi seqüenciado para muitas das amostras analisadas para o gene $\mathrm{COI}$ em busca de variabilidade genética que pudesse auxiliar no entendimento das relações entre as espécies do grupo fraterculus e entre diferentes populações da espécie nominal A. fraterculus.

O seqüenciamento do gene ND6 resultou em um total de $492 \mathrm{pb}$. A composição média de nucleotídeos dos 28 indivíduos analisados foi 38,6\% de A, 16,0\% de $\mathrm{C}, 8,2 \%$ de $\mathrm{G}$ e $37,2 \%$ de $\mathrm{T}$. A média da distância genética de Jukes-Cantor analisada foi $0,016 \pm 0,001$, tendo o nível de divergência de seqüência variado de 0,0 a 0,056 . Dos 492 caracteres usados nas análises, 46 foram variáveis e 30 foram variáveis informativos sob parcimônia.

Assim como para o COI, na análise do ND6 as amostras de $A$. fraterculus mostraram-se agrupadas para as localidades de Vacaria e Caçador e neste caso também a amostra de Chapecó. As demais amostras brasileiras ocorreram como parte de um grande agrupamento com amostras de A. sororcula, A. obliqua e A. amita. Os exemplares das localidades de Mérida e Sevilha apresentaram-se distantes das outras amostras de $A$. fraterculus (Figura 4).

Com exceção da localidade de Presidente Prudente, as amostras de $A$. obliqua formaram um único agrupamento e bastante próximo geneticamente de amostras de $A$. fraterculus, $A$. sororcula e $A$. amita.

A existência de variação intrapopulacional foi pesquisada neste gene, para algumas das espécies até quatro indivíduos foram seqüenciados (Tabela 2). Em nenhum dos casos foi constatada variação intrapopulacional.

O seqüenciamento e comparação de oito indivíduos provenientes de Chapecó, quatro que apresentavam características morfológicas normais no ápice do acúleo e quatro indivíduos com malformação no ápice do acúleo, também foi conduzido 
para o gene ND6. O alinhamento das seqüências nao mostrou divergência entre os indivíduos, e no alinhamento desse gene, apresentado no Apêndice 3, consta apenas o exemplar normal.

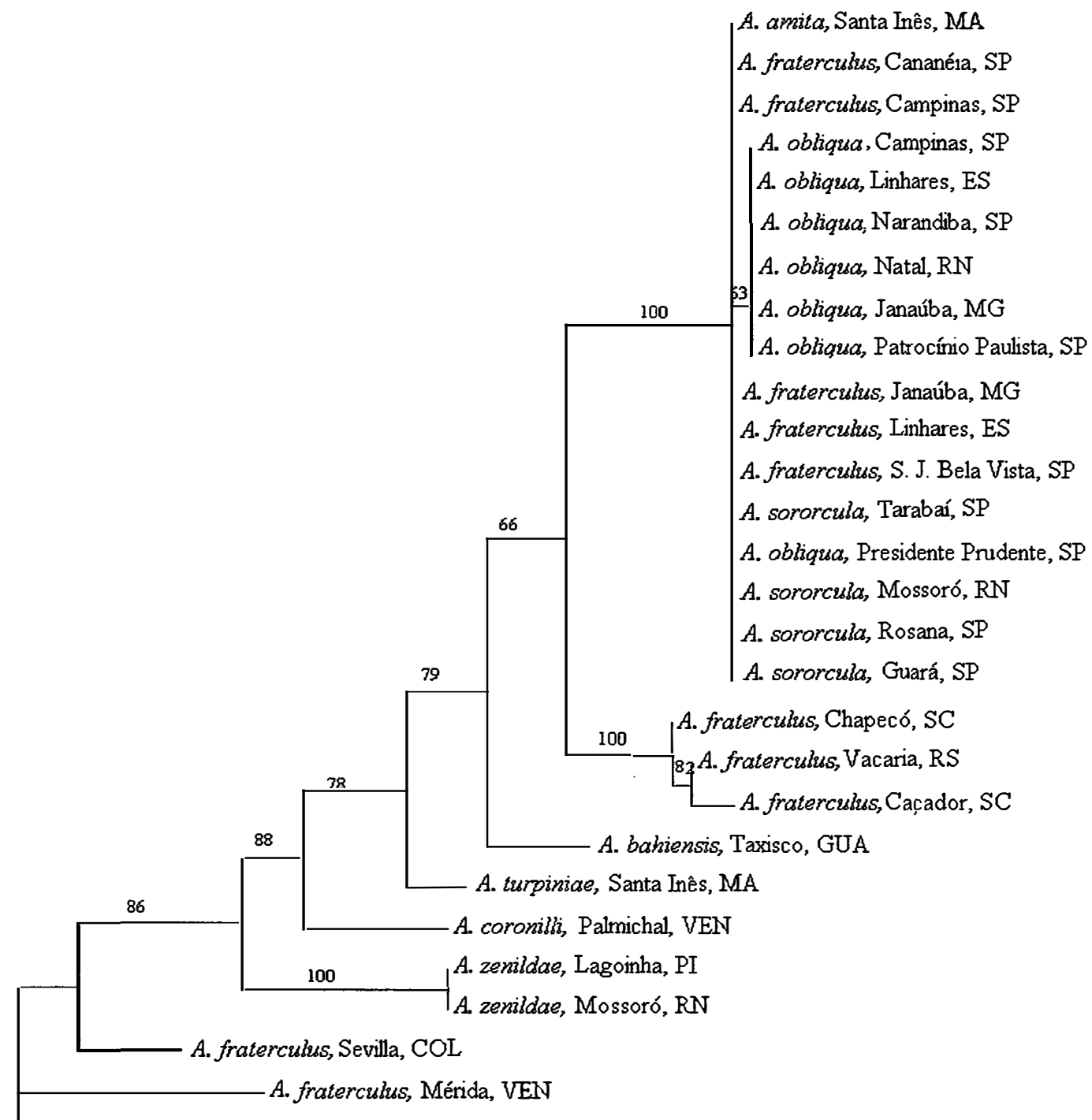

- 0,001 distância Jukes-Cantor

Figura 4. Relações filogenéticas entre espécies do grupo fraterculus inferidas para o gene ND6, com base no método de NJ e distância genética de JukesCantor. Os números nos ramos indicam os valores de "bootstrap" superiores a $50 \%$ (100 replicações). 


\section{1.3 Análise conjunta dos genes COI e ND6}

A análise conjunta dos dois genes resultou em 1300 pb. Na Figura 5 está o filograma gerado pelo método NJ. A média da distância genética de Jukes-Cantor para os 19 espécimens analisados foi $0,0035 \pm 0,002$, tendo o nível de divergência de seqüência variado de 0 a 0,089 .

As análises de MP e os respectivos valores de "bootstrap" para os genes COI e ND6 encontram-se no Apêndice 1 (Figura A). Dos 1.300 caracteres incluídos na análise, 234 foram variáveis, sendo 140 caracteres informativos.

O resultado da análise conjunta manteve as amostras de $A$. fraterculus de Mérida e Sevilla (localidades de altitude elevada) agrupadas e distantes geneticamente das demais amostras dessa espécie, com um forte suporte estatístico. As amostras de Chapecó e Caçador formaram também um agrupamento com forte suporte estatístico. A amostra de Vacaria permaneceu fora do agrupamento, com suporte estatístico moderado, que reuniu as demais amostras de $A$. fraterculus, $A$. obliqua e $A$. sororcula. 


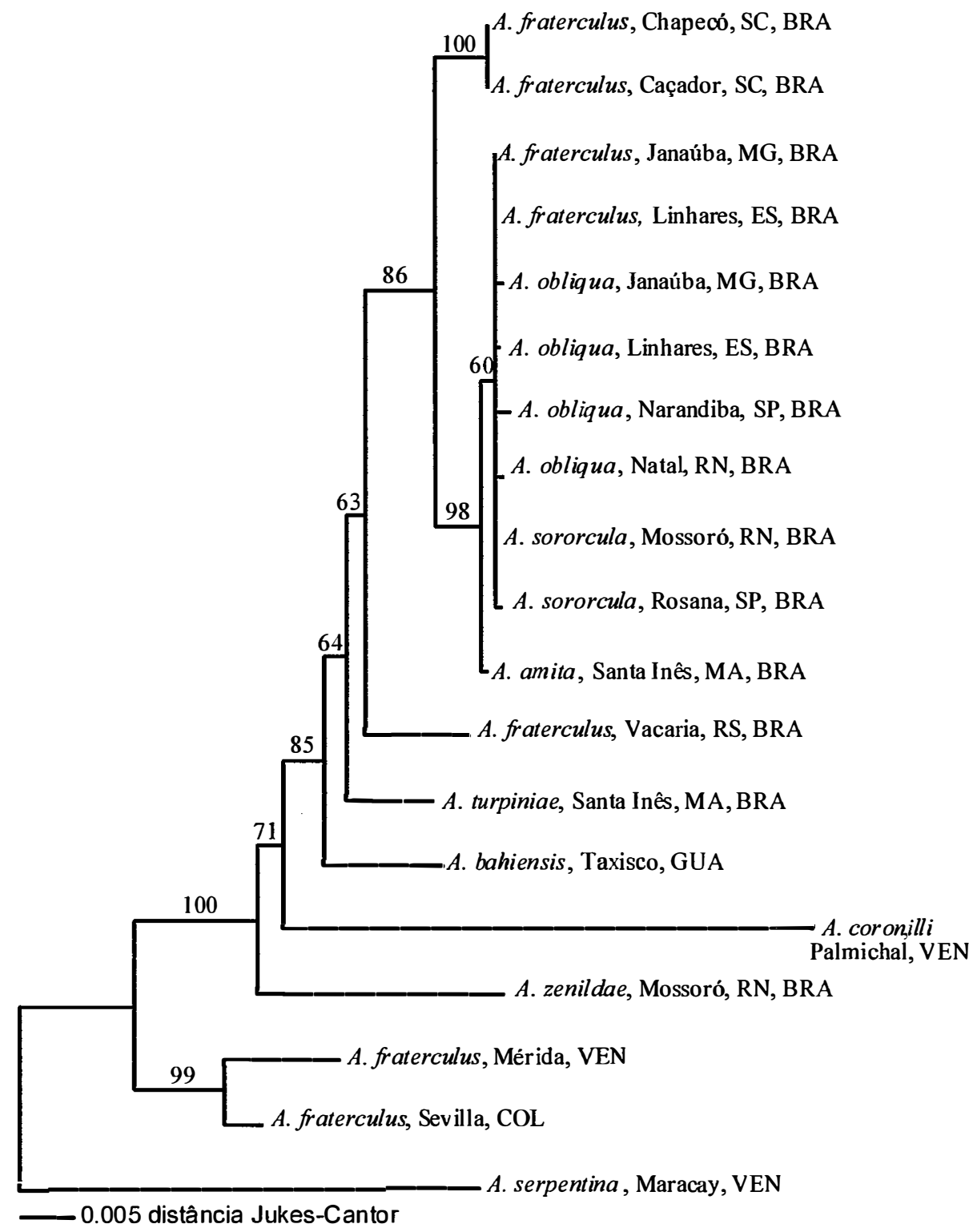

Figura 5. Relações filogenéticas entre espécies do grupo fraterculus inferidas pelo método de $\mathrm{NJ}$ baseada na distância genética de Jukes-Cantor, para a análise conjunta dos genes COI e ND6. Os números nos ramos indicam os valores de "bootstrap" superiores a $50 \%$ (100 replicações). 


\subsubsection{Análise conjunta dos genes COI e 16S}

Considerando-se a disponibilidade dos resultados conseguidos por McPheron et al. (1999), que seqüenciaram o gene $16 \mathrm{~S}$ para espécies do grupo fraterculus, decidiu-se por utilizar parte desse gene.

Aos dados disponíveis foram acrescentadas seis novas seqüências: quatro de A. fraterculus de diferentes localidades, uma de $A$. obliqua e uma de A. distincta. A análise conjunta desses genes resultou em $1.297 \mathrm{pb}$. A média da distância genética de Jukes-Cantor para os 17 indivíduos analisados foi $0,030 \pm 0,0001$, tendo o nível de divergência de seqüência variado de 0 a 0,066 .

Na Figura 6 é apresentado o resultado da análise para os genes COI e parte do $16 \mathrm{~S}$ inferidas pelo método NJ. Na análise de MP, a qual se encontra disponível no Apêndice 1(Figura B), dos 1.297 caracteres incluídos, 214 foram variáveis e 108 foram informativos.

As amostras de $A$. fraterculus provenientes da Venezuela (Mérida) e da Colômbia (Sevilha) continuaram formando um grupo à parte.

A combinação de dados manteve A. acris entre as espécies do grupo fraterculus e $A$. barbiellinii no limite do grupo.

As amostras de $A$. obliqua que se mostraram agrupadas para o gene COI (Actopan, MEX e Sevilla, COL), também aparecem juntas e com suporte estatístico forte nesta análise conjunta. 


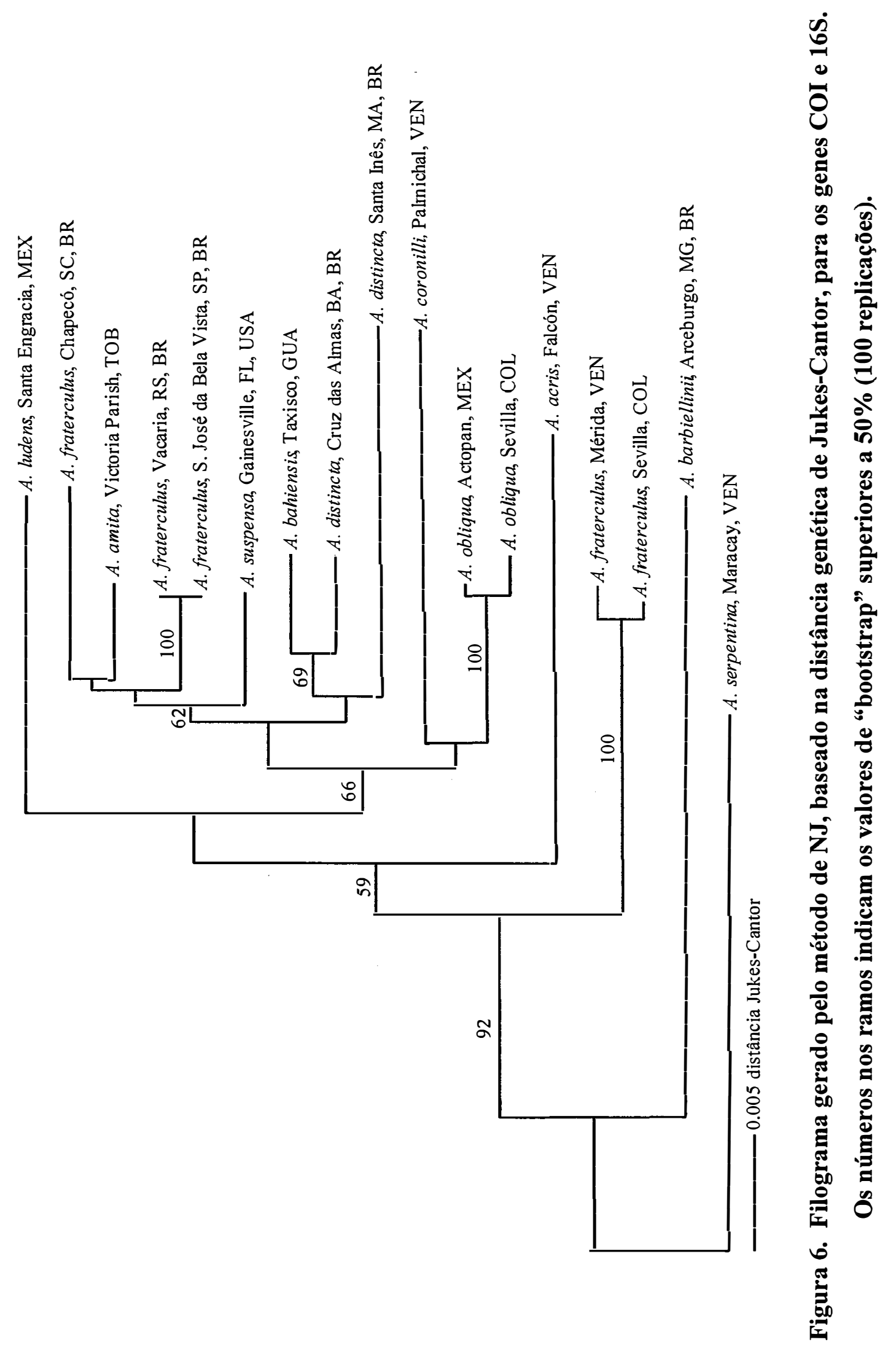




\subsection{Variabilidade genética na espécie nominal “A. fraterculus”- PCR-RFLP}

O seqüenciamento da região compreendida entre parte dos genes COI e COII evidenciou a presença de uma região intergênica entre o tRNA ${ }^{\text {Leu }}$ e o gene COII. A análise da variabilidade genética da espécie nominal $A$. fraterculus através da enzima de restrição $P s i \mathrm{I}$, mostrou a existência de cinco padrões de restrição para essa mesma região. Na Tabela 7, estão os resultados conseguidos através desta análise.

Na Figura 7, são mostrados em gel de agarose a 2\%, os fragmentos obtidos pela digestão enzimática. Os mapas de restrição gerados pelo programa Omiga (Oxford Molecular, 1999) confirmaram o número e o tamanho dos fragmentos obtidos (Figura 8).

Os padrões $\mathrm{A}, \mathrm{B}$ e $\mathrm{E}$ tiveram sua ocorrência restrita às populações brasileiras de $A$. fraterculus, enquanto os padrões $\mathrm{C}$ e $\mathrm{D}$ ocorreram na América Central e norte da América do Sul, respectivamente. Na Figura 9, é ilustrada a distribuição geográfica dos diferentes padrões, com ênfase no Estado de São Paulo.

As populações de Campinas, Valinhos e Vinhedo apresentaram variação intrapopulacional com a ocorrência concomitante de dois padrões. A população de Campinas apresentou os padrões B e E, e as populações de Valinhos e Vinhedo apresentaram os padrões A e B (Figura 10).

Pelos resultados, pode-se constatar que a região intergênica é responsável pela variação do número de pares de base presente nos diferentes padrões. É nesta região que também se encontram os sítios de restrição da enzima Psi $\mathrm{I}$, como mostra o alinhamento (Apêndice 3). 
Tabela 7. Padrões de restrição estabelecidos pela enzima Psi I, sua distribuição nas populações estudadas, a variação de tamanho constatada na região intergênica e o número total de pares de base da região compreendida entre parte dos genes COI e COII em cada um dos padrões.

\begin{tabular}{|c|c|c|c|}
\hline $\begin{array}{l}\text { Padrões de } \\
\text { restrição }\end{array}$ & $\begin{array}{l}\mathrm{N}^{0} \text { de pares de base } \\
\text { na região intergênica }\end{array}$ & $\begin{array}{l}\mathrm{N}^{\mathbf{0}} \text { total de } \\
\text { pares de base }\end{array}$ & $\begin{array}{l}\text { Populações onde ocorreram } \\
\text { os padrões }\end{array}$ \\
\hline Padrão A & 84 & 583 & $\begin{array}{l}\text { Cananéia } \\
\text { Ribeirão Preto, SP } \\
\text { Piracicaba, SP } \\
\text { Vinhedo, SP } \\
\text { Valinhos, SP } \\
\text { Monte Mor, SP } \\
\text { Campinas, SP } \\
\text { Janaúba, MG } \\
\text { Atibaia, SP } \\
\text { São José da Bela Vista, SP } \\
\text { Indaiatuba, SP } \\
\text { Santo Amaro, BA } \\
\text { Linhares, ES } \\
\text { Vacaria, RG }\end{array}$ \\
\hline Padrão B & 86 & 585 & $\begin{array}{l}\text { Cacondé, SP } \\
\text { Valinhos, SP } \\
\text { Vinhedo, SP } \\
\text { Casa Branca, SP } \\
\text { São Paulo, SP } \\
\text { Sorocaba, SP } \\
\text { Monte Alegre, SP } \\
\text { Campinas, SP } \\
\text { Chapecó, SC } \\
\text { Caçador, SC } \\
\text { Tucumán, ARG }\end{array}$ \\
\hline Padrão C & 113 & 612 & $\begin{array}{l}\text { Palin, GUA } \\
\text { Puntarenas, CRA }\end{array}$ \\
\hline Padrão D & 77 & 577 & $\begin{array}{l}\text { Mérida, VEM } \\
\text { Caracas, VEM } \\
\text { Sevilla, COL }\end{array}$ \\
\hline Padrão E & 86 & 585 & Campinas, SP \\
\hline
\end{tabular}




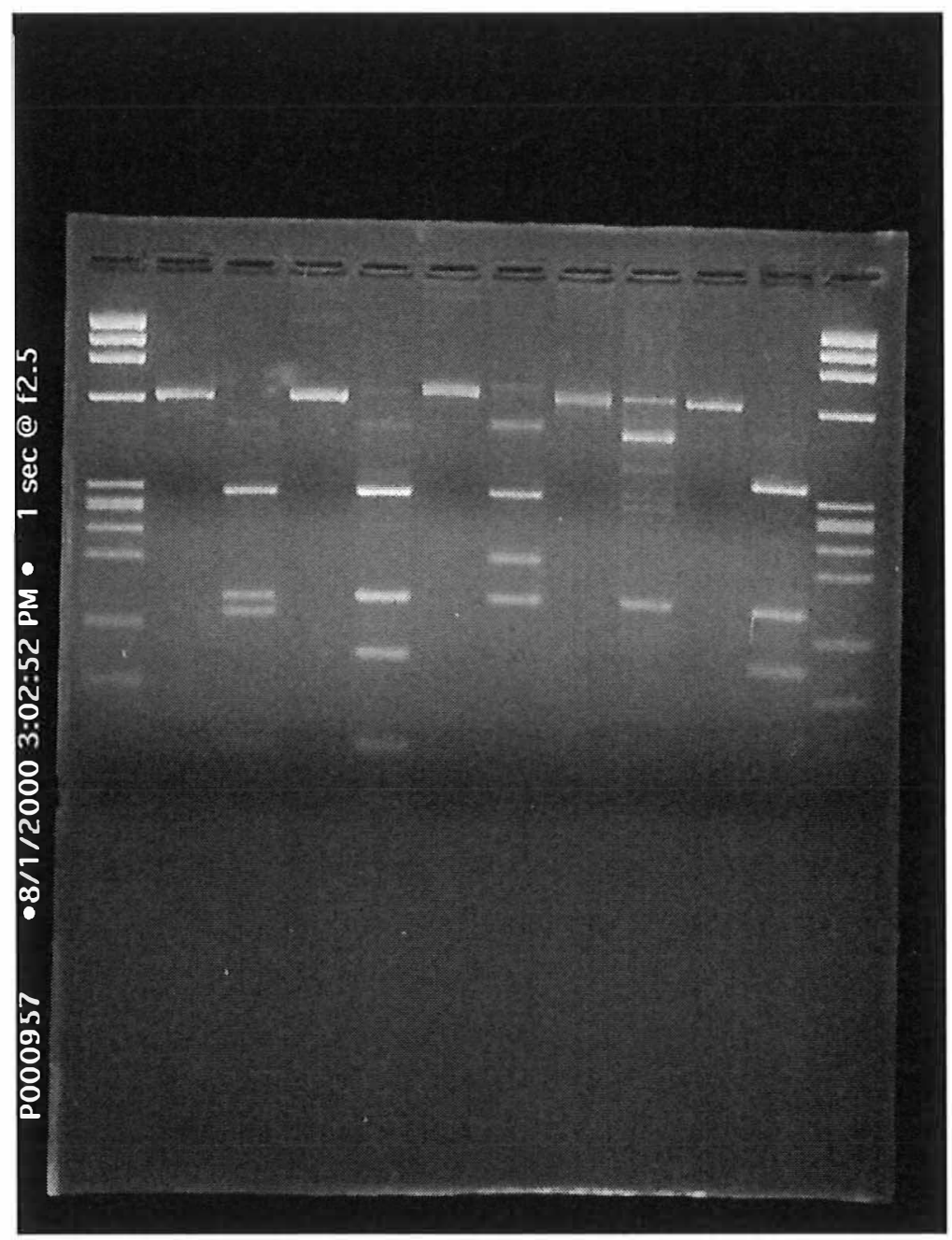

Figura 7. Fragmentos resultantes da digestão enzimática da região intergênica por Psi I para exemplares de $A$. fraterculus evidenciando variação interpopulacional. As linhas pares representam o produto de PCR não digerido e as linhas ímpares representam o produto de PCR digerido. Linhas 2 e 3: padrão A (exemplar de Piracicaba); linhas 4 e 5: padrão B (exemplar de Cacondé); linhas 6 e 7: padrão C (exemplar de Puntarenas); linhas 8 e 9: padrão D (exemplar de Mérida); linhas 10 e 11: padrão E (exemplar de Campinas). Gel de agarose a $2 \%$, marcador de peso molecular $\varnothing \mathrm{X}$ digerido com HaeIII (linhas 1 e 12). 


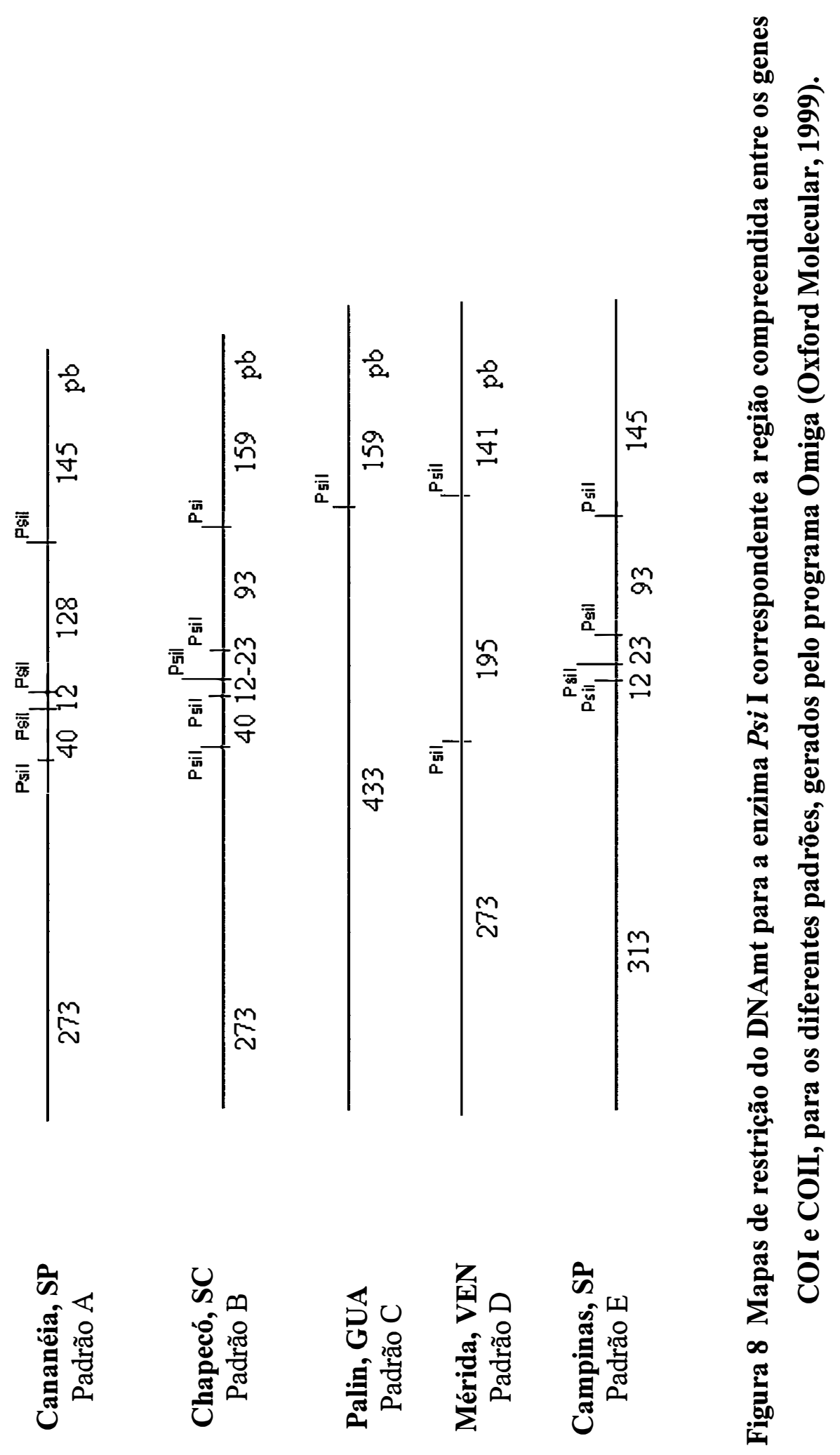




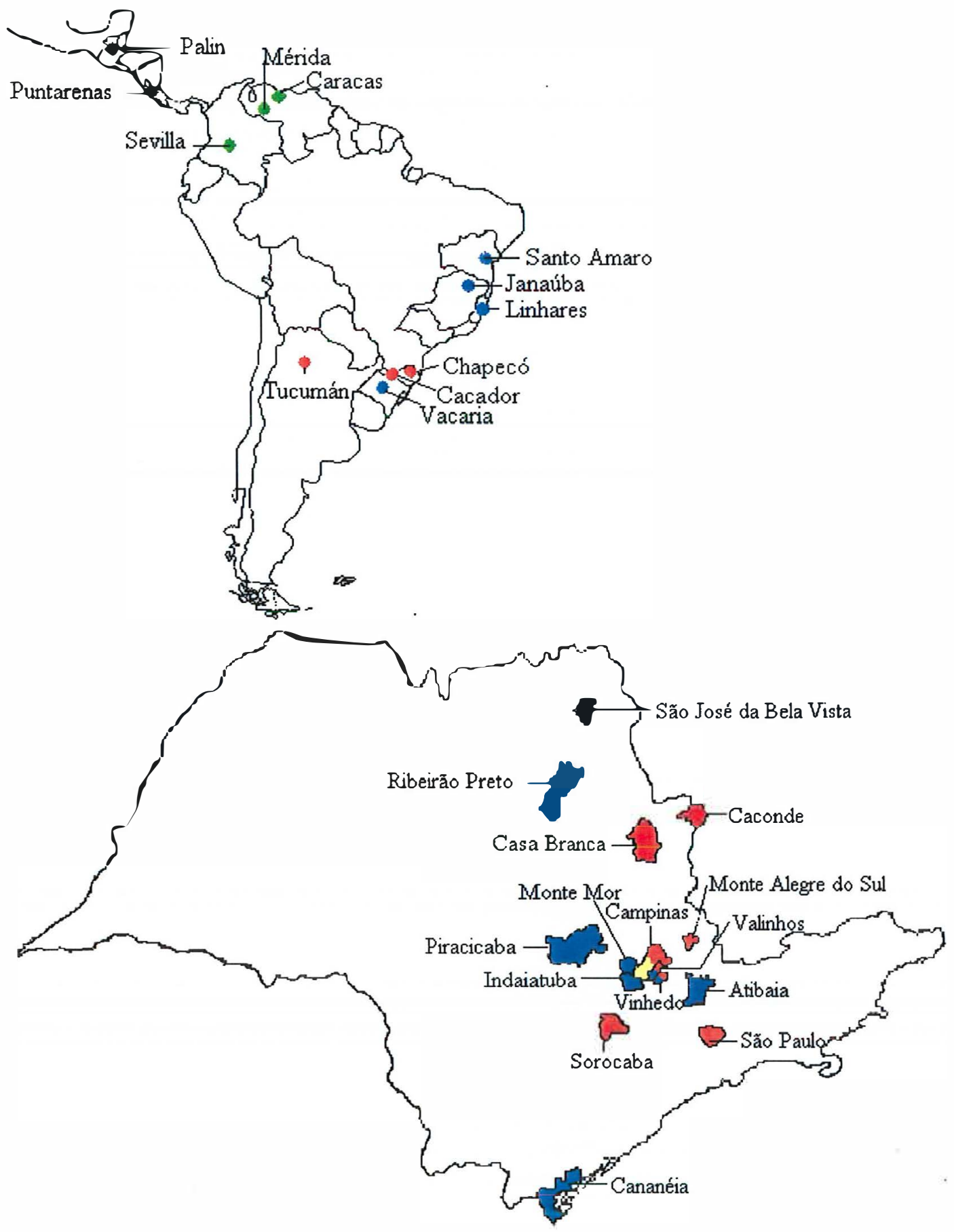

Figura 9. Distribuição geográfica dos padrões gerados pela enzima de restrição $P s i$ I, para a região intergênica, com ênfase ao Estado de São Paulo. Padrão $A$ representado em azul; padrão B representado em vermelho; padrão C representado em verde; padrão $D$ representado em preto e padrão $E$ representado em amarelo. 


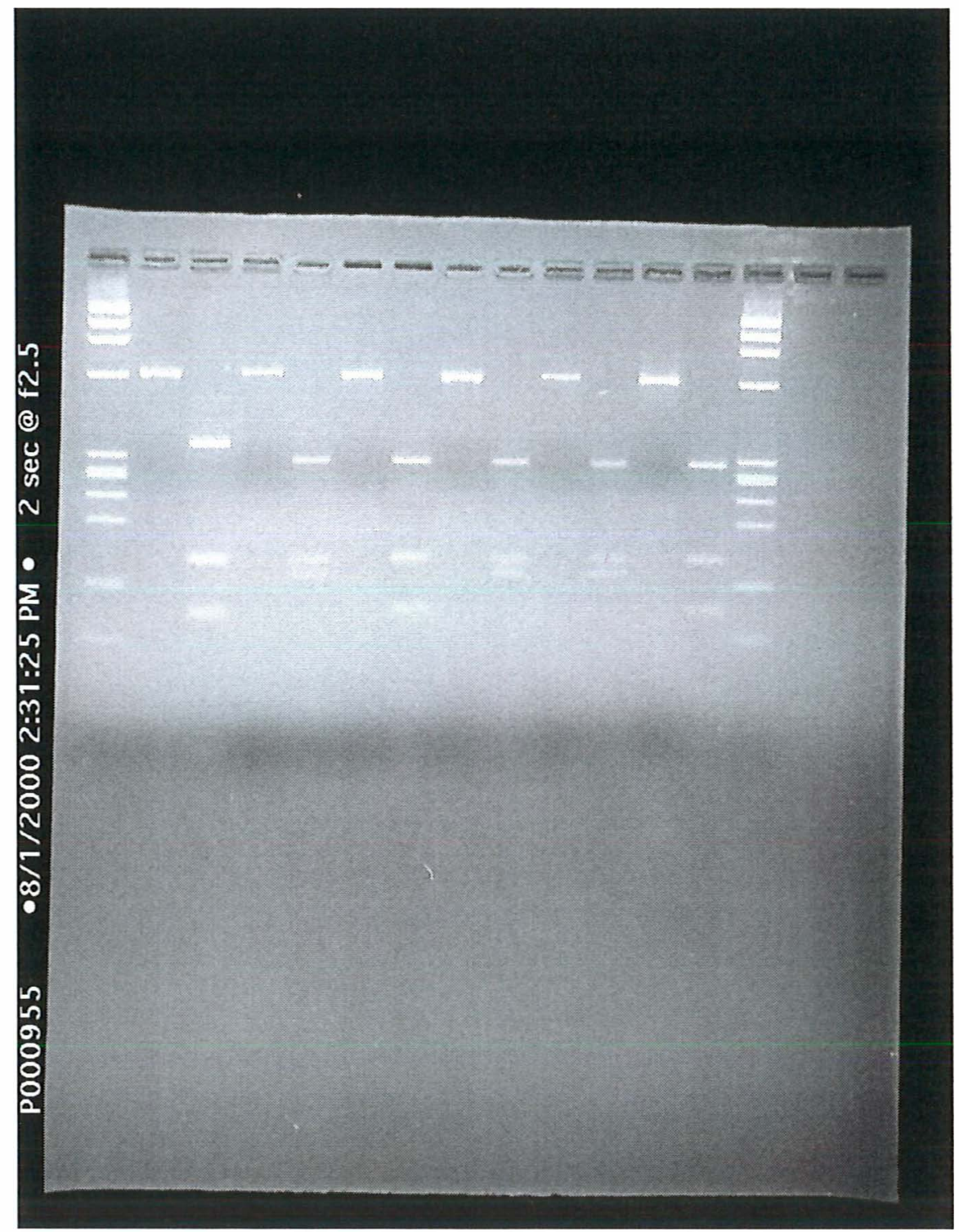

Figura 10. Fragmentos resultantes da digestão enzimática da região intergênica por Psi I para exemplares de $A$. fraterculus das populações que apresentaram variação intrapopulacional. As linhas pares representam o produto de PCR não digerido e as linhas ímpares representam o produto de PCR digerido. Campinas (Linhas 2 a 5), Valinhos (Linhas 6 a 9) e Vinhedo (Linhas 10 a 13). Gel de agarose a $2 \%$, marcador de peso molecular $\varnothing \mathrm{X}$ digerido com HaeIII (Linhas 1 e 14). 


\section{DISCUSSÃO}

Como extensamente revisado nesse trabalho, o grupo fraterculus compreende espécies muito próximas morfologicamente, das quais apenas algumas foram estudadas através de técnicas moleculares. A semelhança desse grupo de insetos tem sido estudada e discutida em diversos níveis, visando a reconstrução da sua filogenia. Steck (1991) e Steck \& Sheppard (1993), também questionaram a origem monofilética de $A$. fraterculus sem, no entanto, prover resultados suficientes para comprovar essa teoria. Norrbom et al. (1999), baseados em caracteres morfológicos, consideraram o grupo fraterculus monofilético ressaltando caracteres apomórficos e sinapomórficos.

No presente trabalho, discute-se a variabilidade genética do grupo fraterculus com base na análise de genes mitocondriais. Este é o mais extenso estudo molecular conduzido para o grupo fraterculus, tanto em número de espécies como em número de populações disponíveis para cada espécie, ainda que espécimens de todos os representantes do grupo não pudessem ser obtidos.

\subsection{Gene COI}

$\mathrm{Na}$ análise desse gene, os exemplares de $A$. sororcula de duas populações diferentes (RN e SP) foram colocadas no mesmo agrupamento com populações de $A$. fraterculus e de $A$. obliqua provenientes apenas de localidades brasileiras. As populações de $A$. sororcula apresentaram-se mais próximas das populações de $A$. fraterculus do que daquelas de $A$. obliqua. 
A distribuição geográfica, as características morfológicas, a biologia e a genética das espécies em questão também reforçam os resultados obtidos nesse estudo.Essas três espécies são morfologicamente muito semelhantes, sendo distinguidas por características sutis na morfologia do ápice do acúleo, sendo os limites específicos difíceis de serem delimitados no caso de alguns exemplares ou populações (Araujo et al., 1997). A. sororcula é mais abundante nos estados do Nordeste, apresentando sobreposição geográfica com $A$. fraterculus e $A$. obliqua as quais são amplamente distribuídas em praticamente toda a extensão latitudinal do gênero (Malavasi et al., 2000).

$A$. fraterculus e $A$. sororcula apresentam comportamento sexual típico das espécies generalistas, diferindo apenas em relação ao horário de cópula (Morgante et al., 1993). Também apresentam grande similaridade em relação aos cariótipos, com diferenças apenas no que se refere aos cromossomos sexuais (Solferini \& Morgante, 1987). Com relação ao uso de hospedeiros, $A$. obliqua infesta preferencialmente frutos da família Anacardiaceae enquanto $A$. sororcula e $A$. fraterculus tem como hospedeiros preferenciais frutos da família Myrtaceae, sendo que as duas últimas espécies podem ser encontradas simpatricamente no mesmo hospedeiro (Malavasi et al., 1980; Zucchi, 1988).

A proximidade entre $A$. sororcula e $A$. fraterculus é condizente com os resultados de Selivon (1996), onde as amostras de A. sororcula provenientes do Nordeste do Brasil são muito próximas à $A$. fraterculus em seus marcadores isozímicos, ainda que agrupadas de forma independente. McPheron et al. (1999) também reforçaram a relação entre $A$. sororcula e $A$. fraterculus para o gene 16S. Santos (1994) analisou o DNAmt de duas populações de $A$. sororcula e duas de $A$. obliqua, além de $A$. fraterculus, as quais mostraram grande similaridade genética entre si, tal qual foi observado neste estudo. Uma diferença genética marcante entre $A$. obliqua e $A$. fraterculus foi detectada em um estudo isozímico realizado por Matioli et al. (1986), no 
qual os autores encontraram dois locos que codificam para a enzima ADH em $A$. fraterculus e três locos em $A$. obliqua.

Santos (1999) conduziu cruzamentos experimentais entre as espécies $A$. fraterculus, A. obliqua e A. sororcula. Os cruzamentos entre fêmeas de $A$. sororcula e machos de $A$. fraterculus e entre fêmeas de $A$. obliqua e machos de $A$. sororcula produzem machos e fêmeas férteis. Os cruzamentos entre fêmeas de $A$. fraterculus ou $A$. sororcula com machos de $A$. obliqua produziram somente fêmeas. Segundo aquela autora, a introdução de fêmeas em locais cuja densidade populacional é elevada, eqüivale a uma situação de cruzamento sem escolha, na qual os resultados desses cruzamentos interespecíficos podem se repetir. Esses resultados evidenciam a possibilidade de que hibridação natural possa estar ocorrendo entre essas espécies.

A. turpiniae e A. amita foram analisadas geneticamente pela primeira vez nesse estudo, ocorrendo no mesmo agrupamento. Não há trabalhos sobre a biologia e comportamento de nenhuma dessas duas espécies até o momento. $\mathrm{O}$ único hospedeiro conhecido para A. amita pertence à família Verbenaceae (Souza-Filho, 1999), enquanto vários hospedeiros de diferentes famílias foram registrados para $A$. turpiniae (Araujo et al., 1999).

Essa condição de grande proximidade genética entre algumas das espécies do grupo fraterculus havia sido reportada em trabalhos anteriores que estudaram marcadores isozímicos (Steck, 1991; Selivon, 1996) ou do DNA mitocondrial e nuclear (Steck \& Sheppard, 1993; Santos, 1994; Santos, 1999).

As amostras de $A$. distincta mostraram uma estreita relação com A. bahiensis e A. fraterculus proveniente de Palin (GUA), sendo as duas últimas mais próximas entre si do que de $A$. distincta (Figura 2). Essas três espécies são morfologicamente próximas e também infestam hospedeiros da família Myrtaceae. Embora os hospedeiros preferenciais de $A$. fraterculus estejam incluídos nessa família, $A$. bahiensis tem como hospedeiros preferenciais frutos da família Moraceae e $A$. distincta infesta preferencialmente frutos da família Mimosaceae (especialmente espécies do gênero 
Inga) (Norrbom \& Kim, 1988; Silva et al., 1996; Zucchi, 2000b). Não há na literatura disponível estudos sobre biologia ou citogenética para A. bahiensis ou A. distincta, entretanto outros estudos genéticos foram realizados. Selivon (1996) apresentou um dendrograma gerado pelo método UPGMA no qual as amostras de $A$. distincta mostraram ser geneticamente mais próximas de A. bahiensis. A mesma relação foi apontada por McPheron et al. (1999) pela análise do gene 16S e repetiu-se na análise conjunta dos genes COI e 16S desse estudo (Figura 6). Na análise isozímica conduzida por Steck (1991), as populações de A. distincta mostraram-se mais próximas de populações de $A$. fraterculus provenientes do Brasil (Bahia), Venezuela (Caracas), Costa Rica e México.

As oito populações de $A$. obliqua não foram recuperadas como um grupo monofilético no presente estudo. Quatro amostras formam um agrupamento com suporte estatístico forte, o qual inclui espécimens de Conceição do Almeida (BA), Sevilla (COL), Los Tuxtlas e Actopan (MEX). As demais amostras de A. obliqua formaram um segundo agrupamento, no qual as duas amostras de $A$. sororcula e as quatro amostras brasileiras de $A$. fraterculus estão presentes (Figura 2 e Figura 3). Estudos anteriores utilizando isozimas (Steck, 1991; Selivon, 1996) não revelaram diferenciação entre as amostras de $A$. obliqua. Uma possível explicação seria que em ambos os estudos, um número menor de amostras foi incluído - no primeiro estudo apenas duas populações brasileiras foram incluídas e no último, apenas populações brasileiras foram analisadas. Um estudo mais aprofundado da estrutura genética populacional dessas espécies de ampla distribuição geográfica faz-se necessário para resolver esta questão.

A espécie $A$. acris, sem grupo definido com base na morfologia de acordo com Norrbom et al. (1999), foi incluída no grupo fraterculus com suporte estatístico forte (85) na análise de MP (Figura 3). Esse resultado é consistente com o encontrado por McPheron et al. (1999) para o gene 16S. Não há muitas informações disponíveis a respeito de $A$. acris, exceto pelo registro de um hospedeiro da família Euphorbiaceae (Norrbom et al., 1999) e pelo registro de seu comportamento sexual que envolve chamada ao final da tarde (Aluja et al., 1999). 
A. barbiellinii aparece separada das outras espécies do grupo fraterculus por A. striata, espécie pertencente ao grupo striata. Os resultados obtidos por McPheron et al. (1999), em seu estudo empregando o gene $16 \mathrm{~S}$, também indicaram que a referida espécie encontra-se distante das demais espécies do grupo fraterculus analisadas. Norrbom et al. (1999) sustentam a colocação de $A$. barbiellinii no grupo fraterculus com base em caracteres morfológicos, no entanto, atentam para uma exceção com relação a esta espécie: a ausência de mancha lateral no mediotergito e subescutelo. Aqueles autores ressaltaram que essa inclusão era apenas tentativa. Um dado interessante a respeito de $A$. barbiellinii refere-se ao fato do seu hospedeiro (o único identificado até o momento) pertencer à família Cactaceae, não tendo sido registrados hospedeiros dessa família para nenhuma outra espécie de Anastrepha até o momento. $\mathrm{O}$ estudo de outros genes dessa espécie e a inclusão de outras espécies do grupo fraterculus ajudaria a esclarecer essa questão e, provavelmente, nova avaliação será necessária.

As amostras de $A$. zenildae formaram um agrupamento do qual faz parte a amostra de $A$. fraterculus de Caracas (VEN) (Figura 2). A. zenildae, espécie morfologicamente próxima de $A$. fraterculus, tem distribuição geográfica restrita ao Brasil e a maioria dos seus hospedeiros pertence à família Myrtaceae (Araujo, 1997; Zucchi, 2000b). Não há registro a respeito da biologia dessa espécie ou estudos genéticos anteriores que possam ser utilizados para comparação.

As populações de $A$. fraterculus mostraram-se agrupadas de forma singular. Um agrupamento foi formado por amostras provenientes dos Andes colombianos e venezuelanos (Sevilla, La Mesa e Mérida), sem a presença de amostras brasileiras e com forte suporte estatístico. Essa é uma forte evidência de que esses espécimens de $A$. fraterculus dessas regiões de elevada altitude sejam uma entidade biológica distinta. Estudos morfológicos, genéticos, comportamentais e a análise dessa espécie em relação às demais espécies do grupo seriam de grande valia na caracterização dessa nova espécie. 
Steck (1991) encontrou a mesma situação para a amostra de $A$. fraterculus de Mérida, que se agrupou com a amostra de São Paulo (Itaquera), mostrando haver uma grande diferença entre as populações andinas e de locais de baixa altitude na Venezuela. Aquele autor sugeriu que as duas amostras da Venezuela poderiam representar duas espécies distintas, o mesmo sendo válido para a amostra de São Paulo que representaria uma terceira espécie. No estudo conduzido por McPheron et al. (1999), a amostra de $A$. fraterculus proveniente de Mérida (VEN) mostrou uma distância genética em relação à amostra de $A$. fraterculus de Bertioga (SP) maior do que a média da distância entre as outras espécies do grupo presentes no estudo.

Ambas as análises, NJ e MP (Figuras 2 e 3), geraram um agrupamento de cinco amostras de A. fraterculus. Duas do Estado de São Paulo (Monte Alegre do Sul e São José da Bela Vista), duas do Sul do Brasil (Vacaria e Caçador) e a única amostra disponível para Argentina, para as quais a análise de NJ mostrou um forte suporte estatístico.

Um pequeno agrupamento foi formado pelas amostras de Chiapas (MEX) e Puntarenas (CRA), juntamente com A. suspensa, que teve um suporte estatístico fraco. Seria interessante a inclusão de espécimens provenientes de outras localidades do México em uma análise futura para que se pudesse comparar com amostras do Brasil, visto que há indícios de diferenças marcantes entre as populações brasileiras e mexicanas. Estudos de morfologia (Stone, 1942), cariótipo (Bush, 1962) e diferenças no horário de chamada dos machos (Aluja et al., 1999) apontam nessa direção.

\subsection{Gene ND6}

De maneira geral, os resultados dessa análise são congruentes com os resultados gerados para o COI. Nessa análise ficou evidenciada uma proximidade ainda maior entre $A$. fraterculus, $A$. obliqua e $A$. sororcula com forte suporte estatístico. A população de $A$. amita do Maranhão (Santa Inês) passa a fazer parte desse agrupamento. $\mathrm{Na}$ análise do gene COI a população de Victoria Parish (TOB) dessa espécie aparece agrupada com $A$. turpiniae. Visto o forte suporte estatístico, é possível concluir que a 
menor proximidade entre essas espécies torna-se válida somente para amostras brasileiras (Figura 4).

As únicas populações brasileiras a formar um agrupamento a parte foram as provenientes do sul do Brasil (Chapecó, Vacaria e Caçador). Analisado separadamente, esse resultado pode indicar a presença de um conjunto gênico diferente na espécie nominal $A$. fraterculus.

No que se refere às amostras provenientes de locais de altitude elevada, essa foi a única análise em que as mesmas não aparecem agrupadas. No entanto, elas continuam no limite do grupo e distanciadas das demais amostras de $A$. fraterculus.

A inclusão ou exclusão de populações pode ser responsável pelas diferenças topológicas nas árvores geradas para os diferentes métodos

\section{3 Genes COI e ND6}

A análise conjunta dos genes COI e ND6 reforça a colocação da população de $A$. amita de Santa Inês (MA) no agrupamento com as amostras de $A$. fraterculus, $A$. obliqua e A. sororcula (Figura 5).

A formação do agrupamento das amostras de $A$. fraterculus do sul do Brasil também é reforçada, porém a amostra de Vacaria não faz parte do mesmo, aparecendo em um outro ramo da árvore. A posição relativa dessas populações nas análises já comentadas pode ser devido a variabilidade encontrada em cada gene.

\section{4. Genes COI e 16S}

Os resultados para a análise conjunta desses genes reforçam as relações descritas por McPheron et al. (1999) para o gene 16S separadamente. As amostras brasileiras incluídas, Vacaria (RS) e São José da Bela Vista (SP), formaram uma grupamento com forte suporte estatístico e mantiveram-se afastadas das amostras de Mérida (VEN) e Sevilla (COL) (Figura 6). As considerações feitas para o gene COI são 
válidas para a análise conjunta dos genes $\mathrm{COI}$ e $16 \mathrm{~S}$, no que diz respeito as populações de altitude elevada.

Para Norrbom et al. (1999), características apomórficas e sinapomórficas sugerem que o grupo fraterculus seja monofilético. Como características apomórficas, os autores citaram a coloração amarelada do mediotergito e subescutelo apresentando ou não faixas escuras laterais e surstilo lateral usualmente paralelo, unido ou truncado apicalmente. $\mathrm{O}$ ápice do acúleo pode ser considerado uma característica sinapomórfica dependendo do nível de comparação, e usualmente se apresenta parcialmente serreado e com constrição basal na parte cercada. Sendo assim, no que diz respeito a monofilia do grupo, existe uma divergência entre dados morfológicos e moleculares, pelo menos no que se refere às regiões do DNAmt analisadas nesse estudo. Os resultados do presente estudo não corroboram a monofilia do grupo fraterculus quando se considera $A$. barbiellinii como pertencente a esse grupo. Todas as outras espécies do grupo fraterculus, quando A. barbiellinii é excluída, apresentam-se como um grupo monofilético embora com suporte estatístico moderado. McPheron et al. (1999) consideraram que o suporte estatístico do gene 16S para monofilia não é suficientemente forte, sendo, porém, consistente com os baixos níveis de divergência para aquele gene entre as espécies analisadas.

O avanço de estudos moleculares e isozímicos mostraram que a espécie nominal A. fraterculus não tem origem monofilética (McPheron et al. 1999; Selivon, 1996; Steck, 1991). A formação de diferentes agrupamentos entre as populações estudadas, como já discutido, sugere a existência de diferentes conjuntos gênicos. Estudos moleculares adicionais, visando a sistemática, irão auxiliar no entendimento das relações entre as espécies do grupo fraterculus. Outrossim, a compreensão da morfologia, biologia e comportamento desses insetos, analisados em conjunto, serão essenciais para o conhecimento desse grupo de espécies (Aluja, 1999). 


\subsection{Caracteres morfológicos e dados moleculares}

Estudos taxonômicos detalhados conduzidos por outros pesquisadores permitem correlacionar caracteres morfológicos aos dados moleculares disponíveis na tentativa de analisar os limites específicos das espécies estudadas.

Maior atenção deve ser dispensada às espécies com as quais $A$. fraterculus apresenta estreita relação, segundo os dados moleculares. Considerando-se que as diferenças entre essas espécies estão relacionadas principalmente ao formato do acúleo, alista-se a seguir, algumas características morfológicas das espécies do grupo fraterculus:

A. fraterculus - coloração geral amarelada; acúleo variando de 1,40 a 1,90 $\mathrm{mm}$ de comprimento; ápice variando entre 0,20 e $0,30 \mathrm{~mm}$ de comprimento; serra apresentando dentes arredondados ocupando aproximadamente a metade apical; acentuada constrição antes da serra (Araujo et al., 1999).

A. amita - descrita a partir de holótipo fêmea proveniente de Cruz das Almas, BA, apresenta semelhança com A. fraterculus e A. bahiensis, das quais difere pelo aspecto do ápice do acúleo, que apresenta leve constrição antes da serra, cujos dentes são arredondados e pouco salientes sobre a metade apical (Zucchi, 1978). A semelhança entre A.amita e $A$. fraterculus fica evidenciada pelas análises do ND6 e COI+ND6. Contudo, A. amita e A. bahiensis não apresentaram relação de grande proximidade. A época da descrição original, os exemplares analisados apresentavam mediotergito totalmente amarelado (Zucchi, 1978). O exame de uma quantidade maior de exemplares, no entanto, mostrou uma grande variação intraespecífica com relação as faixas escuras do mediotergito e subescutelo, podendo ambos ser totalmente amarelados ou apresentar faixas escuras laterais (Souza Filho et al., 1999).

A. bahiensis - em nenhum momento esta espécie foi confundida com $A$. fraterculus. Stone (1942) elevou-a à categoria de espécie baseado no comprimento curto do acúleo. Zucchi (1978) fez consideração a respeito da semelhança entre A. bahiensis e 
A. distincta, as quais diferem pelo tamanho do acúleo e por $A$. bahiensis apresentar dentes diminutos que ocupam menos da metade apical e uma leva constrição antes da serra. Nas análises para as quais amostras de $A$. distincta estavam disponíveis, $A$. bahiensis aparece acompanhada dessa espécie (Figura 2 e Figura 6). No caso em que $A$. distincta não foi analisada (gene ND6, Figura 4) A. bahiensis aparece em um ramo isolado da árvore.

A. distincta - segundo Zucchi (1977) assemelha-se à A. fraterculus. No entanto, o ápice do acúleo de $A$. distincta difere por ser mais longo e apresentar os dentes da serra menos acentuados. Essa proximidade não foi confirmada pelas análises moleculares.

A. obliqua - a principal diferença entre $A$. fraterculus e $A$. obliqua está no ápice do acúleo. Em $A$. obliqua os dentes do ápice são agudos e proeminentes e a constrição da serra é pouco acentuada (Zucchi, 1977). Araujo (1997) relatou grande amplitude no comprimento médio do acúleo entre indivíduos de uma mesma população, sendo esses valores um pouco acima daqueles citados por Zucchi (1978).

A. sororcula - as semelhanças morfológicas entre $A$. sororcula e $A$. fraterculus são muito grandes, sendo a principal diferença o comprimento do ápice do acúleo. Em A. sororcula a constrição antes da serra é mais curta que em $A$. fraterculus (Zucchi, 1977). Existe uma sobreposição na medida do comprimento do acúleo de $A$. fraterculus, $A$. obliqua e $A$. sororcula, como observada na estreita semelhança genética entre populações dessas espécies no Brasil.

A. zenildae - difere de A. fraterculus por apresentar dentes mais próximos da abertura cloacal e suave constrição antes da serra (Zucchi, 1977). Possui o ápice do acúleo com uma suave constrição antes da porção serreada e dentes estendendo-se por mais ou menos $2 / 3$ do ápice. Os comprimentos do acúleo variam entre 1,70 e 2,10 e do ápice do acúleo variam entre 0,28 e 0,36 mm (Araujo et al., 1999).Apesar de não haver sobreposição considerável nas medidas do comprimento do acúleo, as populações de A.zenildae agruparam-se com uma única população de A.fraterculos (Caracas, VEN). 
Em estudo morfométrico conduzido por Araujo (1997) com $A$. fraterculus, A. obliqua, A. zenildae, A. turpiniae e $A$. sororcula, o comprimento do ápice do acúleo foi utilizado como parâmetro no agrupamento das populações. Os resultados revelaram a formação de dois grupos: um deles formado pelas populações de $A$. turpiniae e $A$. zenildae e outro pelas populações de $A$. fraterculus, $A$. obliqua e $A$. sororcula. Essas espécies, apesar de permitirem identificação taxonômica precisa, exigem um acurado senso de observação e conhecimento dos caracteres morfológicos.

Alencar-Souza (1998) conduziu uma análise morfométrica multivariada com populações de $A$. fraterculus, $A$. zenildae e $A$. pickeli provenientes do Rio Grande do Norte. Esse estudo evidenciou o perímetro da asa e as medidas do acúleo como sendo de maior importância discriminante na identificação das espécies.

\subsection{Variação interpopulacional}

As relações entre as populações de uma mesma espécie restringir-se-ão às espécies $A$. fraterculus, $A$. obliqua, $A$. zenildae, A. amita e $A$. distincta, para as quais este estudo analisou de três a 16 populações.

A. distincta - a posição relativa da amostra de Santa Inês (MA), a qual não apresenta suporte estatístico para os métodos NJ e MP, varia conforme o método de análise empregado. Para o NJ, esta amostra aparece distante das outras (Figura 2). Para o MP ela faz parte do mesmo agrupamento (Figura 3). Steck (1991) analisou quatro populações de $A$. distincta que formaram um único agrupamento. Dada a pequena distância genética ( 0,02 distância de Jukes-Cantor) calculada entre a amostra de Santa Inês e as demais e a ausência de suporte estatístico, pode-se considerar que as populações de $A$. distincta são semelhantes.

A. amita - as três populações estudadas mostraram-se próximas. Como uma única população dessa espécie foi estudada anteriormente apenas para o gene $16 \mathrm{~S}$ (McPheron et al., 1999) seria interessante que populações de outras localidades sejam estudadas para comparação com os resultados obtidos nesse trabalho. 
A. zenildae - as populações dessa espécie formaram um único agrupamento com suporte estatístico forte. Esta é a primeira vez que esta espécie foi analisada geneticamente.

A. obliqua - A ocorrência de populações de $A$. obliqua entre as populações de $A$. fraterculus e $A$. sororcula discorda dos resultados apresentados por Steck (1991), Selivon (1996) e Amaral (1994), para os quais as populações de A. obliqua formaram um único grupo. As amostras de Natal (RN) e Linhares (ES) estão incluídas no agrupamento do qual fazem parte as amostras de $A$. fraterculus e $A$. sororcula. Entretanto, o agrupamento no qual se encontram apenas amostras de $A$. obliqua (Figura 2) concorda com os dados de Steck (1991), que utilizou amostras de localidades correspondentes. Essas diferenças podem ser atribuídas ao número de populações estudadas e aos métodos empregados, aqueles pesquisadores fizeram análises isozímicas e a análise deste trabalho empregou genes do DNAmt. A análise de outros genes poderá esclarecer essa questão.

A. fraterculus - definitivamente há diferenciação entre as populações de $A$. fraterculus estudadas. Todos os agrupamentos das populações apresentam forte suporte estatístico, corroborando a hipótese da ocorrência de um complexo de espécies crípticas na espécie nominal $A$. fraterculus. A estes dados soma-se a existência comprovada de pelo menos duas entidades biológicas na espécie nominal $A$. fraterculus em amostras brasileiras, (Selivon, 1996), e a marcante diferenciação notada na população de Mérida (VEN) (Steck, 1991).

\section{7 Análise de RFLP}

Os resultados dessa análise apontam claramente a existência de variação interpopulacional nas populações da espécie nominal $A$. fraterculus estudadas. $\mathrm{O}$ seqüenciamento da região compreendida entre os genes COI e COII apontou a existência de uma região intergênica, entre os genes tRNA ${ }^{\text {Leu }}$ e COII, que apresentou diferenças no número de pares de base presentes e foi responsável pelos diferentes padrões de restrição gerados. 
Smith \& Brown (1988) e Smith (1988) foram os primeiros a reportar a existência de uma região intergênica correspondente em Apis. Crozier et al. (1989) compararam segmentos de DNAmt de A. mellifera ligustica com D. yakuba, cujo DNAmt já havia sido inteiramente seqüenciado (Clary \& Wolstenholme, 1985), porém não puderam caracterizar a região seqüenciada. A atenção de vários pesquisadores foi despertada no sentido dessa região prover divergência suficiente para separar linhagens em Apis, e na busca de esclarecimentos a respeito da sua origem e função (Garnery et al., 1991; Cornuet \& Garnery, 1991; Cornuet et al., 1991; Garnery et al., 1993).

Em moscas-das-frutas especificamente, Smith \& Bush (1997) relataram a existência de um espaço intergênico equivalente. Nos dez grupos pertencentes ao gênero Rhagoletis, estudados pelos referidos pesquisadores, a presença da região intergênica foi confirmada. O número de nucleotídeos varia de 13 (em espécies do grupo cingulata) a 47 (em uma espécie do grupo suavis). Os nucleotídeos puderam ser organizados em estrutura secundária que parece formar um "stem-loop" (Smith \& Bush, 1997).

Cornuet et al. (1991), analisando a origem dessa região em Apis mellifera, descreveram a existência de duas unidades: "P" (100\% composta de $A+T)$, que teria sua origem na região controle, e "Q" cujo conteúdo de CG varia de 93,4 a 94,8\%, e teria sua origem em replicações em "tandem" do tRNA ${ }^{\text {Leu }}$ e na região controle. Para os indivíduos analisados neste estudo, o conteúdo de $\mathrm{A}+\mathrm{T}$ variou de $88,48 \%$ (padrão $\mathrm{C}$ ), a 98,83\% (padrão E). $\mathrm{O}$ número de nucleotídeos da região intergênica em $A$. fraterculus variou de 77 a 113 pb. Em $A$. mellifera varia de 1150 pb a 1600 pb (Cornuet et al., 1991). A existência de estrutura secundária, que define essa região como sendo originária da região controle, não foi encontrada em $A$. fraterculus.

Um fato importante a respeito dessa região em $A$. fraterculus foi que ela permitiu o reconhecimento de cinco padrões de restrição para a enzima Psi I (Figura 7), caracterizando variação interpopulacional. Não parece haver uma distribuição geográfica consistente para os padrões A e B que ocorrem no Brasil. No Estado de São Paulo, onde um número maior de populações foram analisadas, a ocorrência desses padrões se 
sobrepõe. No entanto, São Paulo parece ser o limite máximo longitudinal para a ocorrência do padrão B.

O padrão D ocorreu apenas nas populações de Mérida, Caracas e Sevilla, não tendo sido registrado nas demais localidades amostradas. Segundo Avise et al. (1992), o isolamento geográfico por longos períodos de tempo pode ser responsável pelo surgimento de linhagens distintas de DNAmt. Para o padrão C não é possível fazer este tipo de inferência, visto sua ocorrência em apenas duas populações. $\mathrm{O}$ mesmo é válido para o padrão E, que ocorreu somente em Campinas.

Foi encontrada variação intrapopulacional nos municípios de Campinas, Valinhos e Vinhedo, proximamente localizados. Em Campinas, por exemplo, de 10 indivíduos analisados, nove apresentaram o padrão A e apenas um o padrão E. Para Valinhos, oito indivíduos apresentaram o padrão A e dois o padrão B. Em Vinhedo, oito indivíduos apresentaram o padrão $\mathrm{B}$ e dois o padrão $\mathrm{A}$.

Santos (1994) encontrou alta variação intrapopulacional para $A$. fraterculus que analisou para 12 enzimas de restrição, sendo que 12 indivíduos provenientes de Caçador (SC) apresentaram oito haplótipos diferentes e os 12 indivíduos de Itaquera (SP) analisados apresentaram seis haplótipos.

Considerando-se que a sistemática molecular freqüentemente utiliza apenas um exemplar de cada espécie, a análise deste trabalho foi conduzida na tentativa de se evidenciar variação intrapopulacional. A utilização de uma única enzima capaz de gerar padrões claros de restrição, possibilitou a análise de um maior número de exemplares e populações, sem a necessidade de seqüenciamento de um grande número de espécimens (Tabela 4).

Com relação aos indivíduos de $A$. fraterculus (Chapecó, SC) com ápice do acúleo malformado, não foi possível determinar variação genética. Exemplar com esse tipo de acúleo havia sido descrito como $A$. costarukmanii Capoor, 1955, que foi considerada sinonímia de $A$. fraterculus por Zucchi (1981). Canal (1997) registrou a 
ocorrência de malformações (formato e número de dentes na serra) no acúleo de $A$. zenildae, considerando-as variações intraespecíficas.

Apesar dos genes estudados não mostrarem resolução suficiente para responder questões relativas às relações filogenéticas entre espécies muito próximas, outras questões foram elucidadas. A fim de inferir sobre as relações entre espécies muito próximas, faz-se necessário o estudo de um maior número de indivíduos, que facilitará a constatação de variabilidade. Os resultados pertinentes a posição de A. acris e A. barbiellinii nas árvores filogenéticas geradas são uma evidência da necessidade de revisão da colocação dessas espécies no grupo fraterculus.

A questão da marcada diferenciação entre espécimens de $A$. fraterculus de elevada e baixa altitude na Venezuela pode ser esclarecida com a coleta de indivíduos em transectos planejados. Os dados moleculares gerados a partir desses indivíduos deverão ser analisados conjuntamente com dados de morfologia ecologia e comportamento. 


\section{CONCLUSÕES}

- Pela análise do gene COI, o grupo fraterculus não tem origem monofilética quando $A$. barbiellinii é considerada membro desse grupo.

- Para os genes estudados, A. acris é considerada membro do grupo fraterculus.

- Para os genes estudados, A. barbiellinii está colocada no limite do grupo fraterculus e sua inclusão nesse grupo deve ser revisada.

- A análise de RFLP da região compreendida entre os genes COI e COII apontou variação inter e intrapopulacional na espécie nominal $A$. fraterculus.

- A uma região intergênica entre tRNA ${ }^{\text {Leu }}$ e COII, útil na identificação de diferentes padrões de restrição. 


\section{REFERÊNCIAS BIBLIOGRÁFICAS}

ALENCAR-SOUZA, J. M. G. Caracterização de populações e espécies de moscas-dasfrutas (Diptera, Tephritidae) do Rio Grande do Norte, através de morfometria multivariada. São Paulo, 1998. 79 p. Dissertação (Mestrado) - Instituto de Biociências/Universidade de São Paulo.

ALUJA, M. Bionomics and management of Anastrepha. Annual Review of Entomology, n. 39, p. 155-178, 1994.

ALUJA, M.; PIÑERO, J.; JÁCOME, I.; DÍAZ-FLEISCHER; SIVINSKI, J. Behavior of flies in the genus Anastrepha (Trypetinae: Toxotrypanini). In: ALUJA, M.; NORRBOM, A. L. Fruit flies (Tephritidae): phylogeny and evolution of behavior. CRC Press, Boca Raton, Florida, 1999, p. 375- 408.

AMARAL. P. M. Estudo da variabilidade isozímica de sete locos em larvas de populações naturais de Anastrepha (Diptera: Tephritidae). São Paulo, 1994. 74 p. Tese (Doutorado) - Instituto de Biociências/Universidade de São Paulo.

ARAUJO, E. L. Estudo morfométrico no acúleo de cinco espécies de Anastrepha Schiner, 1868 (Diptera: Tephritidae) do grupo fraterculus. Piracicaba, 1997. 91p. Dissertação (M.S.) - Escola Superior de Agricultura "Luiz de Queiroz", Universidade de São Paulo. 
ARAUJO, E. L.; VELOSO, V. R. S.; SOUZA-FILHO, F. M; ZUCCHI, R. A. Caracterização taxonômica, novos registros de distribuição e de hospedeiros de Anastrepha turpiniae Stone (Diptera: Tephritidae), no Brasil. Anais da Sociedade Entomológica do Brasil, v.28, n.4, p. 657-660, 1999.

ATTARDI, G. Animal mitochondrial DNA: an extreme example of genetic economy. International Review of Cytology, v. 93, p. 93-145, 1985.

AVISE, J. C. Molecular markers, natural history and evolution. Chapman \& Hall. New York, NY. 1994. 511p.

AVISE, J. C. Ten unorthodox perspectives on evolution prompted by comparative population genetic finding on mitochondrial DNA. Annual Review of Genetics, v.25, p.45-69, 1991.

AVISE, J. C.; ALISAUSKAS, R. T.; NELSON, W. S.; ANKNEY, C. D. Matriarchal population genetic structure in an avian species with female natal philopatry. Evolution, v.46, p.1084-1096, 1992.

AVISE, J. C.; LANSMAN, R.A. Polymorphism of mitochondrial DNA in populations of higher animals. In: NEI, M.; KOEHN, R. K. (Eds.) Evolution of genes and proteins. Sinauer, Sunderland, MA, 1983.

BAKER, A. C.; STONE, W. E.; PLUMMER, C. C. A review of studies on the mexican fruit fly and related mexican species. Washington: USDA, 1944. 439p. (USDA. Publication, 531).

BASSO, A.; MANSO, F. Are Anastrepha fraterculus chromossomal polymorfisms an isolation barrier? Cytobios, v.93, p.103-111, 1998.

BROWER, A. V. Z. Phylogeny of Heliconius butterflies inferred from mitochondrial DNA sequences (Lepidoptera: Nymphalidae). Molecular Phylogenetics and Evolution, v.3, n.2, p.159-174, 1994. 
BROWN, B.; EMBERSON, R. M.; PATERSON, A. M. Mitochondrial COI and COII provide useful markers for Wiseana (Lepidoptera: Hepialidae) species identification. Bulletin of Entomological Research, v.89, p.287-293, 1999.

BROWN, J. M.; PELLMYR, O.; THOMPSON, J. N.; HARRISON, R. G. Phylogeny of Greya (Lepidoptera: Prodoxidae), based on nucleotide sequence variation in mitochondrial cytochrome oxidase I and II: congruence with morphological data. Molecular Biology and Evolution, v.11, n.1, p.128-141, 1994.

BROWN, M. W. Population dynamics of invading pests: factors governing success. In: KIM, K, C.; MCPHERON, B. A. (Eds.) Evolution of Insect Pests: Patterns of Variation. John Wiley \& Sons, Inc. New York, NY. 1993.

BROWN, W. M. Evolution of animal mitochondrial DNA. In: NEI, M.; KOEHN, R. K. (Eds.) Evolution of genes and proteins. Sanderland: Sinauer, 1983. Cap.4, p. 62-88.

BUSH, G. L. The cytotaxomony of the larvae of some Mexican fruit flies in the genus Anastrepha (Tephritidae: Diptera). Psyche, v.69, p.87-101. 1962.

BUSH, G. L. Sympatric host race formation and speciation in frugivouros flies of the genus Rhagoletis (Diptera: Tephritidae). Evolution, v.23, p.237-251, 1969.

CANAL D., N. A. Levantamento, flutuação populacional e análise faunística das espécies de moscas-das-frutas (Diptera, Tephritidae) em quatro municípios do norte do Estado de Minas Gerais. Piracicaba, 1997. 74 p. Tese (Doutorado) - Escola Superior de Agricultura “Luiz de Queiroz"/Universidade de São Paulo.

CANAL D., N. A.; ALVARENGA, C. D.; ZUCCHI, R. A. Infestation levels of common guava by Anastrepha zenildae Zucchi (Diptera, Tephritidae) in commercial groves of the North of Minas Gerais State. Anais da Sociedade Entomológica do Brasil, v.27,n.4, 1998. 
CLARY, D. O.; WOLSTENHOLME, D. R. The mitochondrial DNA molecule of Drosophila yakuba: nucleotide sequence, gene organization, and genetic code. Journal of Molecular Evolution, n.22, p.252-271, 1985.

CONDON, M. A.; STECK, G. J. Evolution of host use in fruit flies of the genus Blepharoneura (Diptera: Tephritidae): cryptic species on sexually dimorphic host plants. Biological Journal of the Linnean Society, v.60, p.443-466, 1997.

CORNUET, J. M.; GARNERY, L. Mitochondrial DNA variability in honeybees and its phylogeographic implications. Apidologie, v.22, p.627-642, 1991.

CORNUET, J. M.; GARNERY, L.; SOLIGNAC, M. Putative origin and function of the intergenic region between COI and COII of Apis mellifera L. mitochondrial DNA. Genetics, v.1128, p.393-403, 1991.

CROZIER, R. H.; CROZIER, Y. C.; MACKINLAY, A. G. The CO-I and CO-II region of honeybee mitochondrial DNA: evidence for variation in insect mitochondrial evolutionary rates. Molecular Biology and Evolution, v.6, n.4, p.399-411, 1989.

DE LA RUA, P.; SERRANO, J.; GALIÁN, J. Mitochondrial DNA variability in the Canary Islands honeybees (Apis mellifera L.). Molecular Ecology, v.7, p.15431547, 1998.

EHLICH, P. R.; RAVEN, P. H. Differentiation of population. Science, v.165, p.1228$1232,1969$.

GARNERY, L.; VAUTRIN, D.; CORNUET, J. M.; SOLIGNAC, M. Phylogenetic relationships in the genus Apis inferred from mitochondrial DNA sequence data. Apidologie, v.22, p.87-92, 1991.

GARNERY, L.; SOLIGNAC, M.; CELEBRANO, G.; CORNUET, J. M. A simple test using restricted PCR-amplified mitochondrial DNA to study the genetic structure of Apis mellifera L. Experientia, v.49, p.1016-1021, 1993. 
FAURON, C. M. R.; WOLSTENHOLME, D. R. Intraspecific diversity of nucleotide sequences within the adenine + thymine rich region of mitochondrial DNA molecules of Drosophila mauritiana, Drosophila melanogaster and Drosophila simulans. Nucleic Acids Research, v.8, p.5391-5410, 1980.

FELSENSTEIN, J. Confidence limits on phylogenies: an appproach using bootstrap. Evolution, v.39, p.783-791, 1985.

FOOTE, R. H.; BLANC, F. L.; NORRBOM, A. L. Handbook of the fruit flies of America North of Mexico. Cornell University Press, Ithaca, NY, 571p.

FUTUYMA, D. J. Biologia Evolutiva. Sociedade Brasileira de Genética/CNPq, Ribeirão Preto, SP, 1996, 646p.

FUTUYMA, D. J.; PETERSON, S. C. Genetic variation in the use of resources by insects. Annual Review of Entomology, v.30, p.217-238, 1985.

HAN, H. Y.; McPHERON, B. A. Molecular phylogenetic study of Tephritidae (Insecta: Diptera) using partial sequences of the mitochondrial 16S ribosomal DNA. Molecular Phylogenetics and Evolution, v.7, p.17-32, 1997.

HAN, H. Y.; McPHERON, B. A.. Phylogenetic study of selected tephritid flies (Insecta: Diptera: Tephritidae) using partial sequences of the nuclear $18 \mathrm{~S}$ ribosomal DNA. Biochemical Systematic and Ecology, v.22, p.447-457, 1994.

HARRISON, R. G. Animal mitochondrial DNA as a genetic marker in population and evolutionary biology. Trends in Ecology and Evolution, v.4, p.6-11, 1989.

HAYMER, D. S.; HE, M. Analysis of molecular variation within and between species in the Bactrocera dorsalis complex. In: $5^{\text {th }}$ INTERNATIONAL SYMPOSIUM ON FRUIT FLIES OF ECONOMIC IMPORTANCE. Penang, Malásia, 1998. Resumos. Malásia, 1998, p.63. 
HERNÁNDEZ-ORTIZ, V.; GÓMEZ-ARRAYA, J. A.; SÁNCHEZ, A.; McPHERON, B. A.; ALUJA, M. Morphological variability in natural populations of Anastrepha fraterculus (Wiedmann) from Mexico and South America. In: $3^{\mathrm{RD}}$ MEETING OF THE WORKING GROUP ON FRUIT FLIES OF THE WESTERN HEMISPHERE. Guatemala City, 1999. Resumos. Guatemala, 1999, p.45.

HOY, M. Insect Molecular Genetics - An Introduction to Principles and Applications. San Diego, Academic Press. Inc., 1994. 545 p.

KENNEDY, G. G. Impact of intraspecific variation on insect pest management. In: KIM, K. C.; McPHERON, B. A. (Eds.) Evolution of insect pests. John Wiley \& Sons, Inc., New York, USA, 1993. p.3-25.

KIM, K. C. Insect pests and evolution. In: KIM, K. C.; McPHERON, B. A. (Eds.) Evolution of insect pests. John Wiley \& Sons, Inc., New York, USA, 1993. p.3-25.

KIM, K. C.; McPHERON, B. A. Biology of variation: epilogue. In: KIM, K. C.; McPHERON, B. A. (Ed.) Evolution of insect pests. John Wiley \& Sons, Inc., New York, USA, 1993. p 453-468.

KORYTKOWSKI, C.; OJEDA, D. Especies del genero Anastrepha Schiner 1868 en el nor-oeste peruano. Revista Peruana de Entomologia, v.11, n.1, p.32-70, 1968.

LANSMAN, R. A.; SHADE, R. O.; SHAPIRA, J. F.; AVISE, J. C. The use of restriction endonucleases to measure mitochondrial DNA sequence relatedness in natural populations. III. Techniques and potential applications. Journal of Molecular Evolution, v.17, p.214-226, 1981.

MALAVASI, A. Técnica de aniquilação de machos. In: MALAVASI, A.; ZUCCHI, R. A. (Eds.) Moscas-das-frutas de importância econômica no Brasil. Ribeirão Preto, 2000. 159-160. 
MALAVASI, A. Programas de liberação inundativa de parasitóides para o controle de moascas-das-frutas na América Latina. In: ZAPATER (Ed.), El control biológico en América Latina. 1996. p.129-131.

MALAVASI, A.; ZUCCHI, R. A.; SUGAYAMA, R. L. Biogeografia. In: MALAVASI, A.; ZUCCHI, R. A. (Eds.) Moscas-das-frutas de importância econômica no Brasil. Ribeirão Preto, 2000. p.93-98.

MALAVASI, A.; MORGANTE, J. S. Genetic variation in natural populations of Anastrepha (Diptera; Tephritidae). Revista Brasileira de Genética, v.5, p.263-278, 1982.

MALAVASI, A.; MORGANTE, J. S. Biologia de "moscas-das-frutas" (Diptera: Tephritidae). II. Índices de infestação em diferentes hospedeiros e localidades. Revista Brasileira de Biologia, v.40, p.17-24, 1980.

MALAVASI, A. ; MORGANTE, J. S.; ZUCCHI, R. A. Biologia das "moscas-dasfrutas" (Diptera, Tephritidae). I: lista de hospedeiros e ocorrência. Revista Brasileira de Biologia, v.40, n.1, p.9-16, 1980.

MATIOLI, S. R.; MORGANTE, J. S.; MALAVASI, A. Genetical and biochemical comparisons of alcohol desydrogenase isozymes from Anastrepha fraterculus and A. obliqua (Diptera, Tephritidae): evidence of gene duplication. Biochemical Genetics, v.24, p.13-24, 1986.

MAYR, E. Populations, species and evolution: an abridgment of animal species. Entomologia Experimentalis et Aplicatta, n.46, p.155-160, 1970.

McPHERON, B. A. Population genetics and criptic species. In: $5^{\mathrm{TH}}$ INTERNATIONAL SYMPOSIUM ON FRUIT FLIES OF ECONOMIC IMPORTANCE. Abstract. Penang, Malasia. 1998. p.83. 
McPHERON, B. A. Recent advances and future directions in tephritid populations genetics. In: ALUJA, M.; LIEDO, P. (Eds.) Fruit flies: biology and managment. Springer-Verlag, New York, 1983. p.59-64.

McPHERON, B. A.; HAN, H-Y.; SILVA, J. G.; NORRBOM, A. L. . Phylogeny of the genera Anastrepha and Toxotrypana (Trypetinae: Toxotrypanini) based upon 16S rRNA mitochondrial DNA sequences. In: ALUJA, M.; NORRBOM, A. L. Fruit flies (Tephritidae): phylogeny and evolution of behavior. CRC Press, Boca Raton, Florida, 1999, p.343- 362.

MENDES, L. O. T. Observações Citológicas em "moscas-das-frutas". Bragantia, v.17,p.29-39, 1958.

MORGANTE, J. S.; SELIVON, D.; SOLFERINI, V. N.; MATIOLI, S. R. Evolutionary patterns in specialist and generalist species os Anastrepha. In: ALUJA, M.; LIEDO, P. (Ed.). Fruit flies: biology and management. Sprigger-Verlag, New York, 1993. 492p.

MORGANTE, J. S.; MALAVASI, A.; BUSH, G. L. Biochemical systematics and evolutionary relationships of Neotropical Anastrepha. Annals of the Entomological Society of America, n.73, p.622-630, 1980.

MORITZ, C.; DOWLING, T. E; BROWN, W. M. Evolution of mitochondrial DNA: relevance for population biology and systematics. Annual Review of Ecology Systematic, v.18, p.269-292, 1987.

MORROW, J.; SCOTT, L.; CONDON, B.; YEATES, D.; FROMMER, M.; SVED, J. Close genetic similarity between two sympatric species of tephritid fruit fly reproductively isolated by mating time. Evolution, v.54, n.3, p.899-910, 2000. 
NORRBOM, A. L. Phylogenetic analysis and taxonomy of the cryptostrepha, daciformis, robusta, and schausi species groups of Anastrepha Schiner (Diptera: Tephrtidae). Pennsylvania, 1985. 355p. Thesis (Ph.D) - Pennsylvania State University.

NORRBOM, A. L.; ZUCCHI, R. A.; HERNÁNDEZ-ORTIZ, V. Phylogeny of the genera Anastrepha and Toxotrypana (Trypetinae: Toxotrypanini) based on morphology. In: ALUJA, M.; NORRBOM, A. L. (Eds.) Fruit flies (Tephritidae): phylogeny and evolution of behavior. CRC Press, Boca Raton, Florida, 1999, p. 299- 342.

NORRBOM, A. L.; KIM, K. C. A. list of the report host plant of the species of Anastrepha (Diptera: Tephritidae). Hyattsville: U.S. Dept. Agriculture, Animal and Plant Health Inspecion Service, Plant Protection and Quarantine, 1988. 114p.

ORTIZ, G. Potential use of the sterile inset technique against the South America fruit flies. In: Joint FAO/IAEA Division of Nuclear Techniques in Food and Agriculture. The South America fruit fly, Anastrepha fraterculus (Wied.); advances in artificial rearing, taxonomic status and biological studies. Viña del Mar, Chile, 1999, p.121-130.

SANCHIS, A.; LATORRE, A.; GONZÁLEZ-CANDENAS, F.; MICHELENA, J. M. An 18S rDNA-based molecular phylogeny of Aphidiinae (Hymenoptera: Braconidae). Molecular Phylogenetics and Evolution, v.14, n.2, p.180-194, 2000.

SANTOS, P. Variabilidade genética, isolamento reprodutivo e regra de Haldane em espécies de Anastrepha (Diptera: Tephritidae). São Paulo, 1999. Tese (Doutorado) Instituto de Biociências, Universidade de São Paulo.

SANTOS, P. Variabilidade do DNA mitocondrial em populações de três espécies de Anastrepha (Diptera: Tephritidae). São Paulo, 1994. Dissertação (M.S.) - Instituto de Biociências, Universidade de São Paulo. 
SCARPASSA, V. M.; GEURGAS, S.; AZEREDO-ESPIN, A. M.; TADEI, W. P. Genetic diversity in mitochondrial DNA of Anopheles nuneztovari (Diptera: Culicidae) from Brazil and Colombia. Genetics and Molecular Biology, v.23, n.1, p.71-78, 2000.

SELIVON, D. Estudo sobre a diferenciação populacional em Anastrepha fraterculus (Wiedemann) (Diptera: Tephritidae). São Paulo, 1996. 137p. Tese (Doutorado) Instituto de Biociências, Universidade de São Paulo.

SELIVON, D.; PERONDINI, A. L. P. Eggshell morphology in two cryptic species of the Anastrepha fraterculus complex (Diptera: Tephritidae). Annals of the Entomological Society of America, v.91, p.473-478, 1998.

SILVA, J. G. Estudos moleculares. In: MALAVASI, A.; ZUCCHI, R. A. (Eds.) Moscas-das-frutas de importância econômica no Brasil. Ribeirão Preto, 2000, p. $29-40$.

SIMON, C.; FRATI, F.; BECKENBACH, A.; CRESPI, B.; LIU, H.; FLOOK, P. Evolution, weighting, and phylogenetic utility of mitochondrial gene sequences and a compilation of conserved polymerase chain reaction primers. Annals of Entomological Society of America, v.87, p.651-701, 1994.

SMITH, D. R. Mitochondrial DNA polymorphisms in five Old World subspecies of honey bees and in New World hybrids. In: DELFINADO-BAKER, M.; BOWMAN, C. E. (Eds.). Africanized honey bees and bee mites. Halsted, Needham \& Page, New York, 1988. p.303-312.

SMITH, D. R.; BROWN, W. M. Polymorfisms in mitochondrial DNA of European and Africanized honeybees (Apis mellifera). Experientia, v.44, p.257-260, 1988. 
SMITH, J. J.; BUSH, G. L. Phylogeny of the subtribe Carpomyina (Trypetinae), emphasizing relationships of the genus Rhagoletis. In: ALUJA, M.; NORRBOM, A. L. (Eds.) Fruit flies (Tephritidae): phylogeny and evolution of behavior. CRC Press, Boca Raton, Florida, 1999, 187-218.

SMITH, J. J.; BUSH, G. L. Phylogeny of the genus Rhagoletis (Diptera; Tephritidae) inferred from DNA sequences of mitochondrial cytochrome oxidase II. Molecular Phylogenetics and Evolution, v.7, n.1, p.33-43, 1997.

SOLFERINI, V. N.; MORGANTE, J.S. Karyotype study of eight species of Anastrepha (Diptera: Tephritidae). Caryologia, v.40, p.229-241. 1987.

SOUZA-FILHO, M. F.; RAGA, A.; CANAL D., N. A.; ZUCCHI, R. A. Anastrepha amita Zucchi (Dip., Tephritidae): primeiro registro hospedeiro, nível de infestação e parasitóides associados. Arquivos do Instituto Biológico, v.66, n.2, p.77-84, 1999.

STECK, G. Taxonomic status of Anastrepha fraterculus. In: Joint FAO/IAEA Division of Nuclear Techniques in Food and Agriculture. The South American fruit fly, Anastrepha fraterculus (Wied.); advances in artificial rearing, taxonomic status and biological studies. Viña del Mar, Chile, 1999, p.13-20.

STECK, G. J. Biochemical systematics and population genetic structure of Anastrepha fraterculus and related species (Diptera: Tephritidae). Annals of the Entomological Society of America, v.84, p.10-28, 1991.

STECK, G. J.; SHEPPARD, W. S. Mitochondrial DNA variation in Anastrepha fraterculus. In: ALUJA, M. \& LIEDO, P (Eds.) Fruit Flies: biology and management. Springer-Verlag, New York, NY. 1993. 492p.

STONE, A. The fruit flies of the genus Anastrepha. Washington: USDA, 1942. 439p. (USDA. Publication, 439). 
SWOFFORD, D. L. PAUP*: Phylogenetic analysis using parsimony, version 4.0b1. Sinauer Associates, Sunderland, 1998.

WHITE, I. M.; ELSON-HARRIS, M. M. Fruit flies of economic significance: their identification and bionomics. CAB International, Wallingford, UK, 1992. 601p.

WILSON, A. C.; CANN, R. L.; CARR, S. M.; GEORGE, M.; GYLLENSTEN, U. B.; ET AL. Mitochondrial DNA and two perspectives on evolutionary genetics. Biological Journal of the Linnean Society, v.26, p.375-400, 1985.

ZHANG, D. X.; SZYMURA, J. M.; HEWITT, G. M. Evolution and structural conservation of the control region of insect mitochondrial DNA. Journal of Molecular Evolution, v.40, p.382-391, 1995.

ZUCCHI, R.A. Taxonomia das espécies de Anastrepha Schiner, 1868 do complexo fraterculus (Diptera, Tephritidae). Piracicaba, 1977. 63p. Dissertação (Mestrado) Escola Superior de Agricultura "Luiz de Queiroz", Universidade de São Paulo.

ZUCCHI, R.A. Taxonomia das espécies de Anastrepha Schiner, 1868 (Diptera: Tephritidae) assinaladas no Brasil. Piracicaba, 1978. 105p. Tese (Doutorado) Escola Superior de Agricultura "Luiz de Queiroz", Universidade de São Paulo.

ZUCCHI, R.A. Anastrepha Schiner, 1868 (Diptera: Tephritidae): novas sinonímias. Revista Brasileira de Entomologia, v. 25, n.4, p.289-294, 1981.

ZUCCHI, R.A.. Moscas-das-frutas (Dip., Tephritidae) no Brasil: taxonomia, distribuição geográfica e hospedeiros. In: SOUZA, H. M. L. (Coord.) Moscas das frutas no Brasil. Campinas, SP, Fundação Cargill. 1988. p.1-10.

ZUCCHI, R. A. Taxonomia. In: MALAVASI, A.; ZUCCHI, R. A. (Eds.). Moscas-dasfrutas de importância econômica no Brasil. Ribeirão Preto, 2000a. p.13-24. 
ZUCCHI, R. A. Lista das espécies de Anastrepha, sinonímias, plantas hospedeiras e parasitóides. In: MALAVASI, A.; ZUCCHI, R. A. (Eds.). Moscas-das-frutas de importância econômica no Brasil. Ribeirão Preto, 2000b. p.41-48. 
APÊNDICE 1 


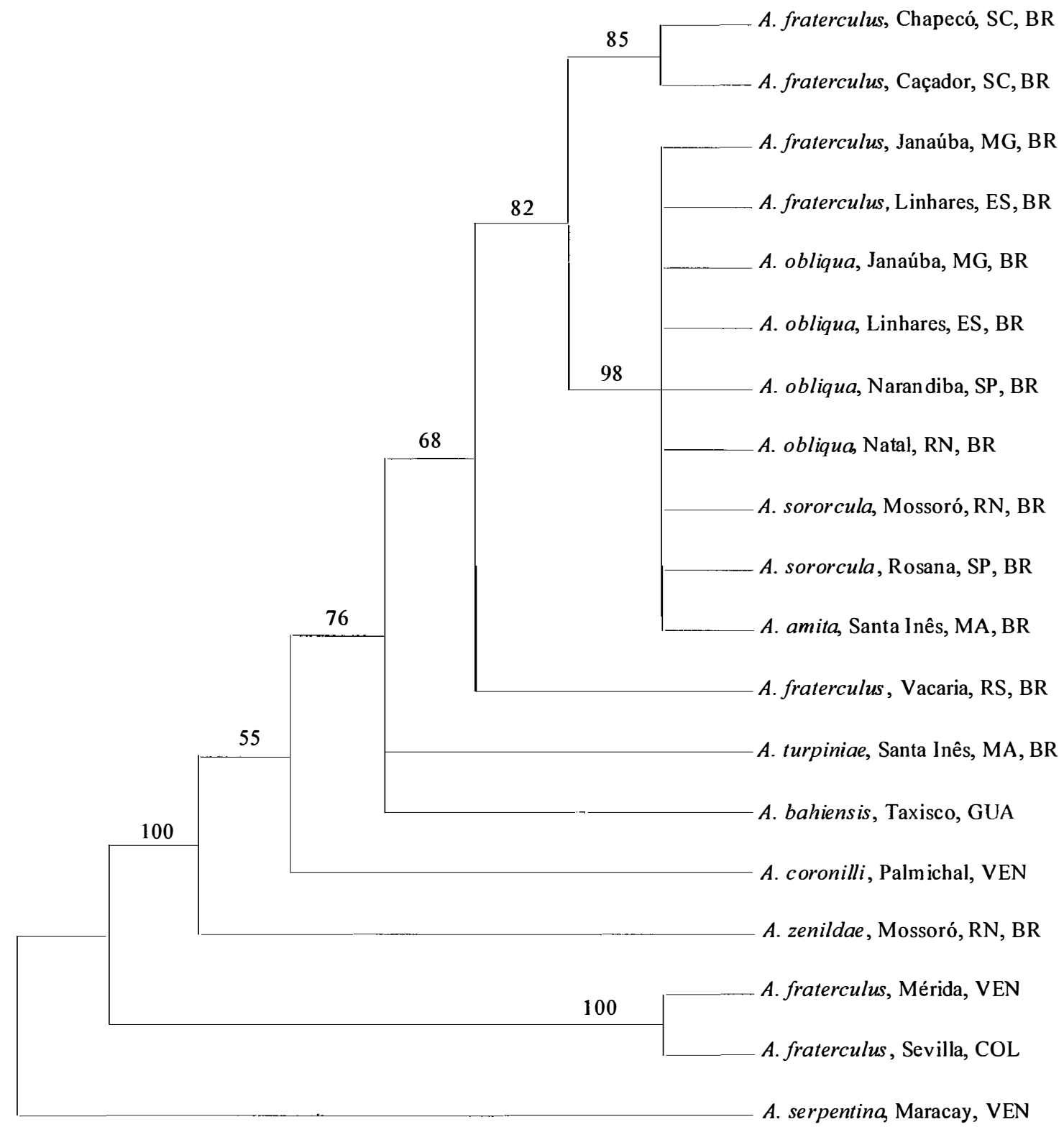

Figura A. Relações filogenéticas inferidas pelo método MP para os genes COI e ND6. Consenso estrito de quatro das mais parcimoniosas árvores. Os números nos ramos indicam valores de bootstrap superiores a $\mathbf{5 0 \%}$ (100 replicações). 


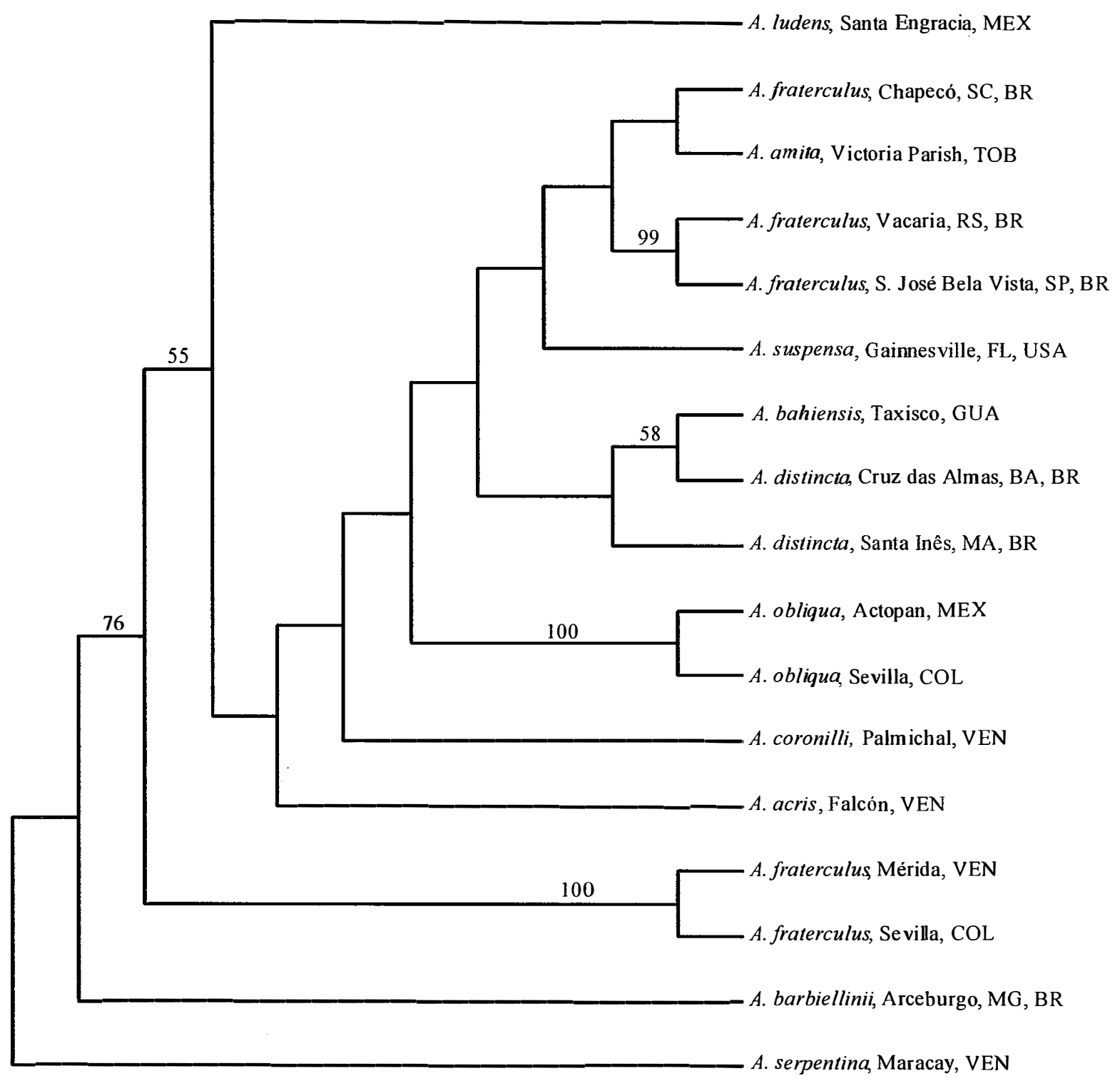

Figura B. Relações filogenéticas inferidas pelo método MP para os genes COI e 16S. Consenso estrito de quatro das mais parcimoniosas árvores. Os números nos ramos indicam valores de "bootstrap" superiores a 50\% (100 replicações). 
APÊNDICE 2 


\section{Protocolo de extração de DNA total segundo Han \& McPheron (1997).}

1. Preparar a solução $\mathrm{X}$ adicionando $1 \mu \mathrm{L}$ da solução estoque de proteinase-K (20 $\mathrm{mg} / \mathrm{ml}$ ) por $200 \mu \mathrm{L}$ de solução.

Obs.: A proteinase- $\mathrm{K}$ deve ser mantida a temperatura de $-20^{\circ} \mathrm{C}$, de onde deve ser retirada somente momentos antes de ser utilizada.

2. Colocar 1 inseto em um tubo Eppendorf de 1,5 mL e adicionar de $200-300 \mu \mathrm{L}$ da solução X. A medida utilizada nesta etapa será a mesma utilizada para a solução Y.

3. Insetos alfinetados devem ser ligeiramente macerados com auxílio de palito de dente e incubados a $55^{\circ} \mathrm{C}$ por 5 minutos.

4. Macerar o inseto a mão utilizando uma ponteira descartável selada. A maceração deve ser suficiente para desintegrar a estrutura dos tecidos.

Obs.: As ponteiras de $1000 \mu \mathrm{L}$ devem ser seladas em bico de Bunsen.

5. Incubar a $55^{\circ} \mathrm{C}$ por 30 minutos.

6. Dez minutos antes de completada a incubação, Preparar a solução Y adicionando $60 \mu \mathrm{L}$ de DEPC fresco por $5 \mathrm{~mL}$ de solução (se o DEPC estiver aberto por mais de uma semana no refrigerador, utilize $80 \mu \mathrm{L} / 5 \mathrm{~mL}$ de solução). Uma vez adicionado o DEPC, misture bem a solução.

7. Adicione $200-300 \mu \mathrm{L}$ de solução Y. Incubar em gelo por 10 minutos.

8. Adicionar igual volume de fenol e homogeneizar até que a mistura se torne esbranquiçada.

Obs.: O volume de fenol será o equivalente a soma das soluções X e Y já adicionadas. Portanto, se foram utilizados $250 \mu \mathrm{L}$ de cada uma dessas soluções, devese utilizar $500 \mu \mathrm{L}$ de fenol.

9. Centrifugar por cinco minutos em microcentrífuga a $14.000 \mathrm{rpm}$ a $4{ }^{\circ} \mathrm{C}$. Preparar tubos Eppendorf para o próximo passo.

10. Com a micropipeta regulada para $400 \mu \mathrm{L}$, remover a camada aquosa superior. Colocar em novo tubo Eppendorf $(1,5 \mathrm{~mL})$. Adicionar igual volume de fenol/ clorofórmio/ álcool isoamil (25:24:1). Homogeneizar a mistura e incubar em gelo por 3 minutos.

11. Centrifugar por cinco minutos em microcentrífuga a $14.000 \mathrm{rpm}$ a $4{ }^{\circ} \mathrm{C}$. Preparar tubos Eppendorf para o próximo passo. 
12. Remover a camada aquosa superior. Colocar em novo tubo Eppendorf $(1,5 \mathrm{~mL})$. Adicionar igual volume de clorofórmio/ álcool isoamil (24:1). Agitar ligeiramente.

13. Centrifugar por cinco minutos em microcentrífuga a $14.000 \mathrm{rpm}$ a $4^{\circ} \mathrm{C}$. Preparar tubos Eppendorf para o próximo passo.

14. Remover a camada aquosa superior. Colocar em novo tubo Eppendorf $(1,5 \mathrm{~mL})$.

15. Adicionar 0,1 volume de amônio acetato e $1000 \mu \mathrm{L}$ de etanol (que pode ser substituido por isopropanol). Inverter gentilmente os tubos 10 vezes. Colocar a $-20^{\circ} \mathrm{C}$ por pelo menos 30 minutos.

16. Centrifugar por $15-20$ minutos em microcentrífuga a $14.000 \mathrm{rpm} \mathrm{a} 4{ }^{\circ} \mathrm{C}$.

17. Remover cuidadosamente o sobrenadante e desidratar o "pellet" no vácuo.

18. Redissolver o "pellet" em 10-100 $\mu \mathrm{L}$ de 1 XTE. Estimar a concentração utilizando DNA "ladder" de $1 \mathrm{~kb}$.

\section{Soluções utilizadas durante a extração.}

Solução X (sem proteinase K)

$0,25 \mathrm{~mL}$ de tris- $\mathrm{HCl}(\mathrm{pH} 8,0) 2 \mathrm{M}$

$2,5 \mathrm{~mL}$ de SDS $10 \%$

$0,6 \mathrm{~mL}$ de $\mathrm{NaCl} 5 \mathrm{M}$

$1 \mathrm{~mL}$ de EDTA (pH 8,0) 0,5M

$40,6 \mathrm{~mL}$ de $\mathrm{H}_{2} \mathrm{O}$ de-ionizada

Solução Y (sem dEPC)

7,5 mL de Tris- $\mathrm{HCl}(\mathrm{pH} 8,0) 2 \mathrm{M}$

$3,7 \mathrm{~mL}$ de SDS a $10 \%$

$5 \mathrm{~mL}$ de sucrose a $50 \%$

$10 \mathrm{~mL}$ de EDTA (pH 8,0) a $0,5 \mathrm{M}$

$23,8 \mathrm{~mL}$ de $\mathrm{H}_{2} \mathrm{O}$ de-ionizada

Após preparadas, as solucões devem ser mantidas congeladas $\left(-20^{\circ} \mathrm{C}\right)$, não havendo aparente efeito adverso em descongelar as mesmas repetidas vezes. 
APÊNDICE 3 


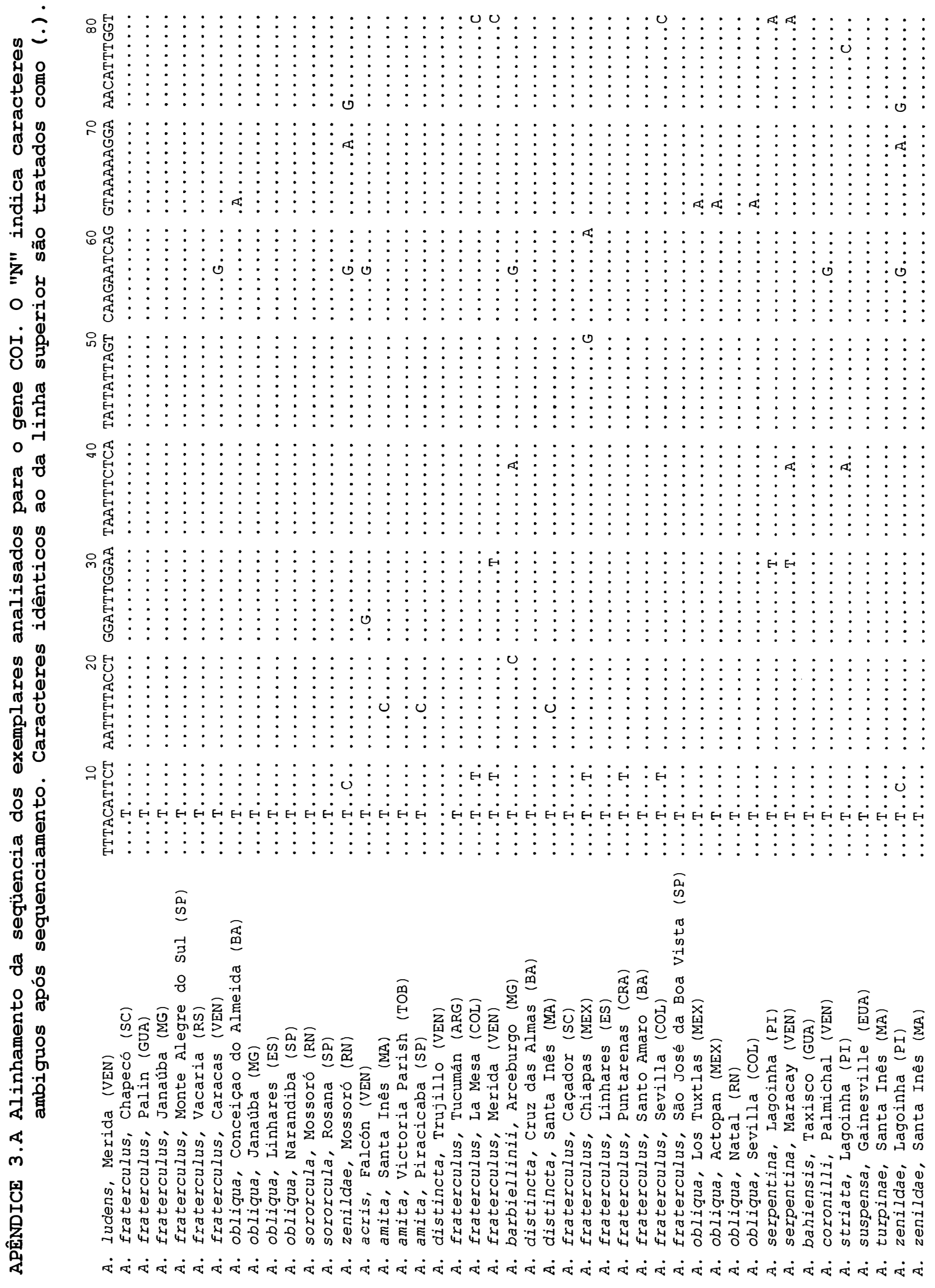




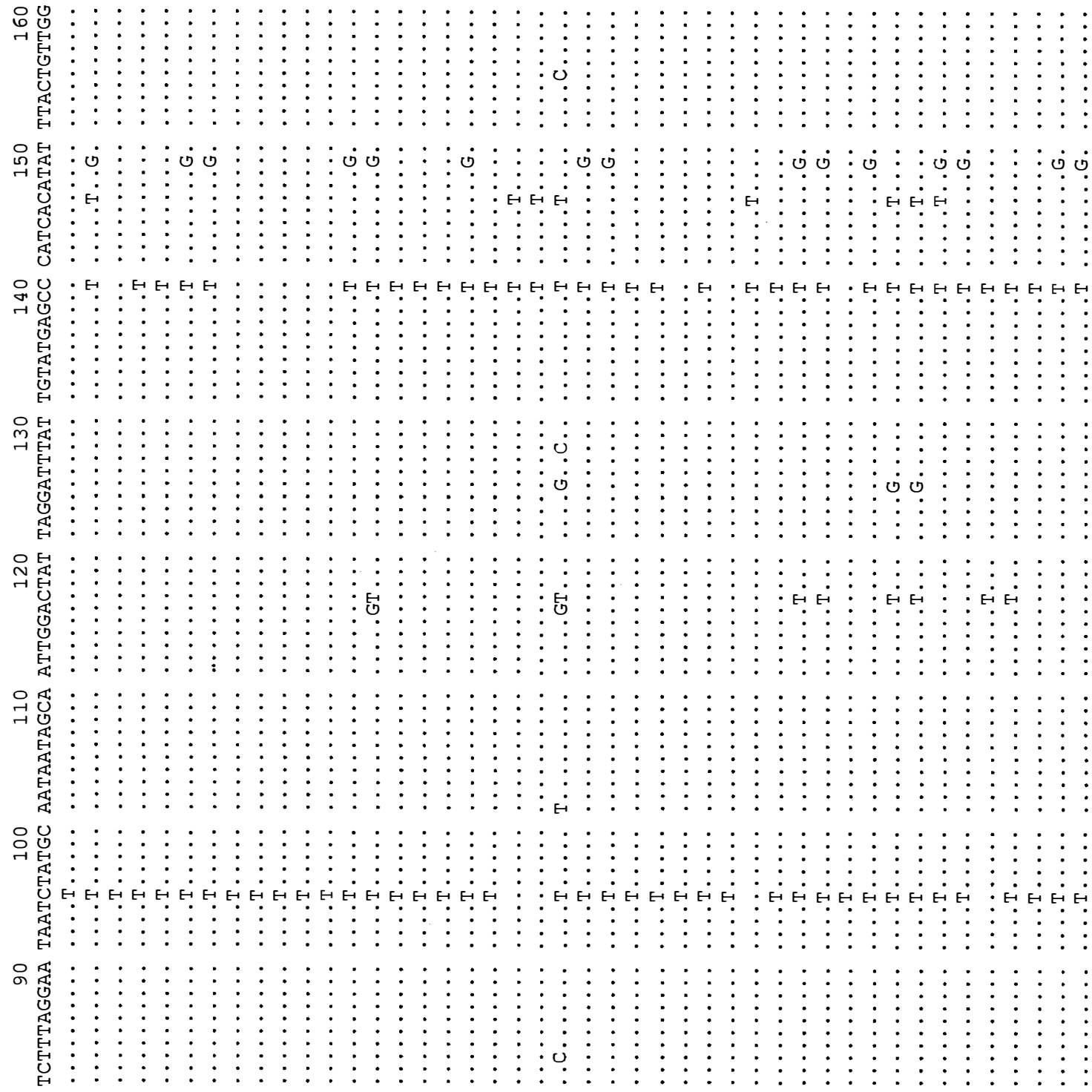

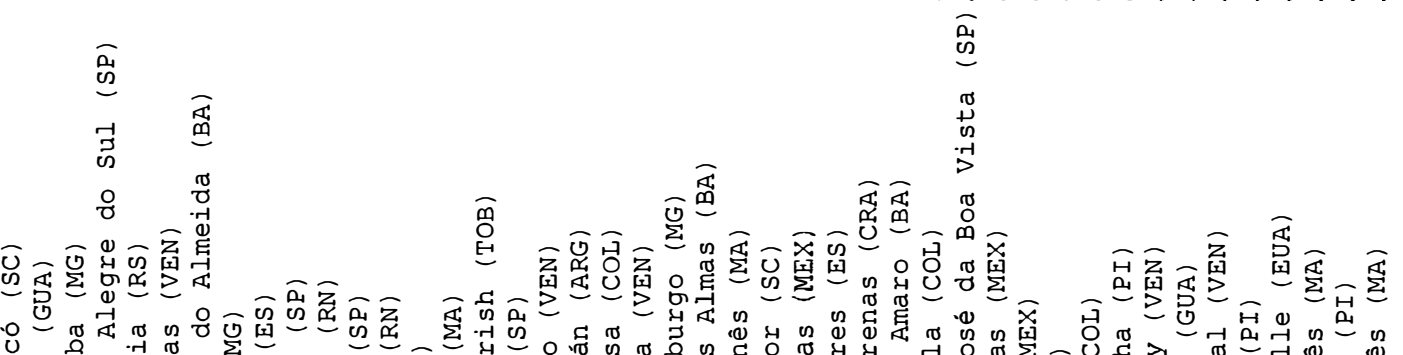

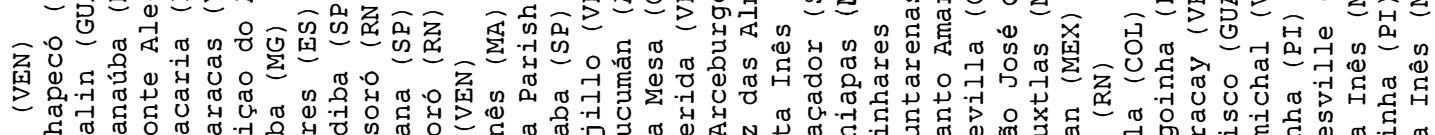

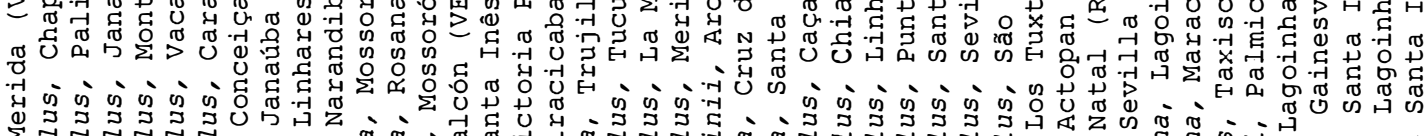

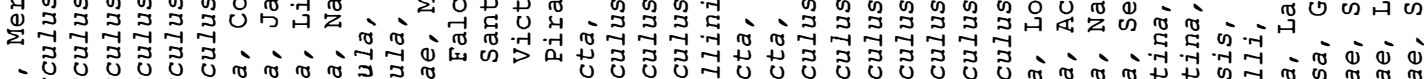

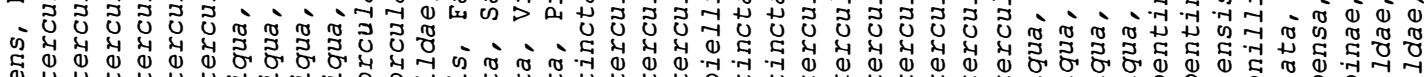

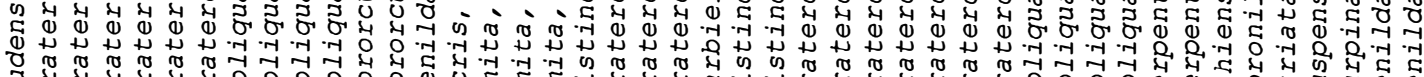

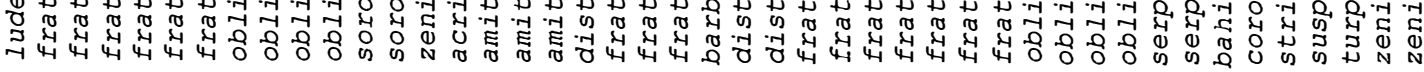

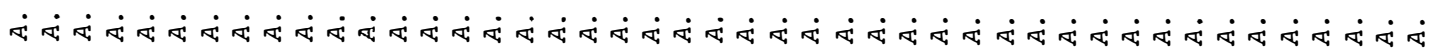



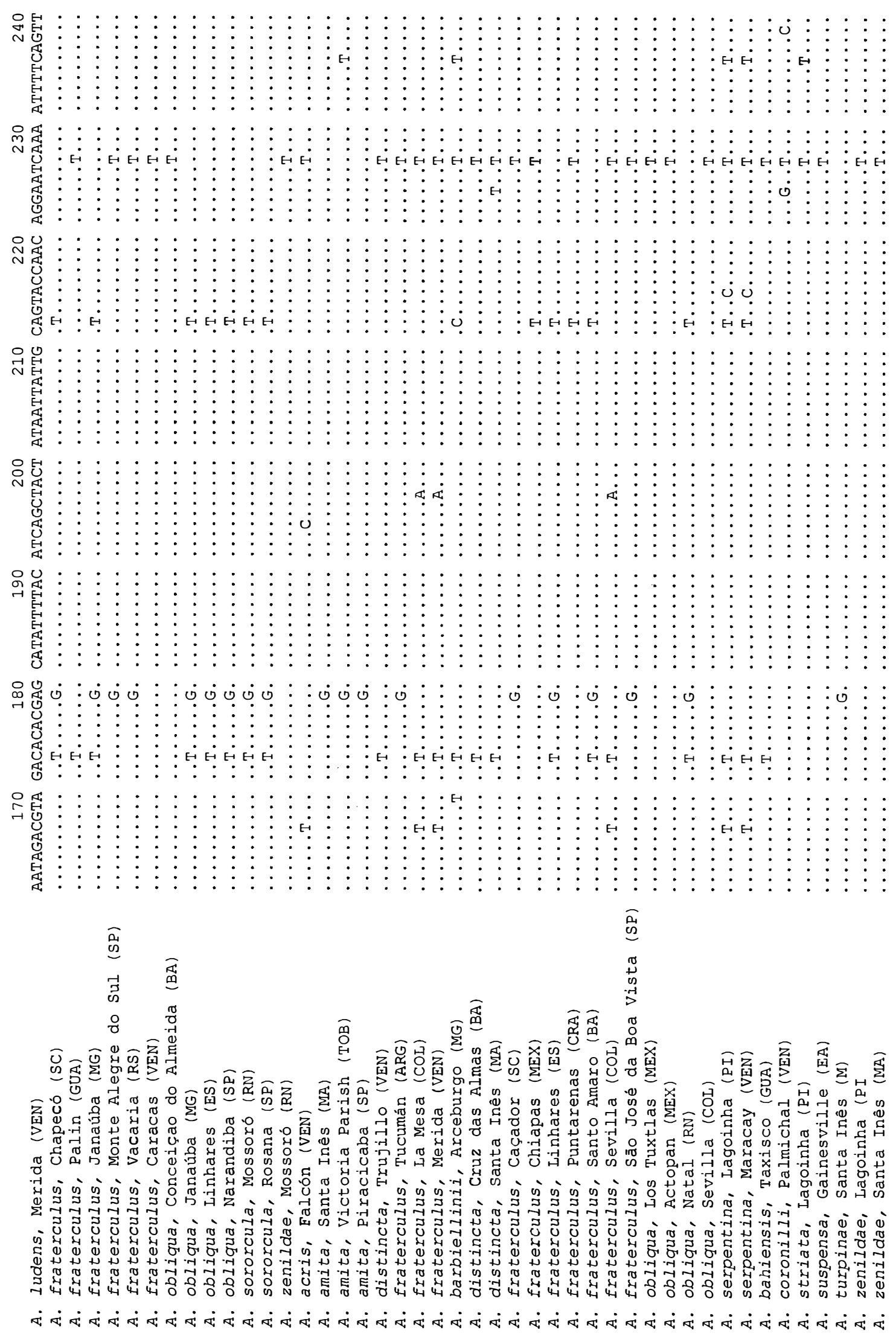


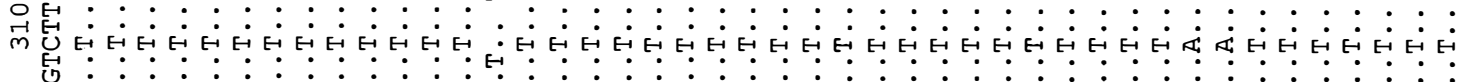
舄

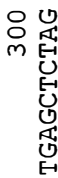

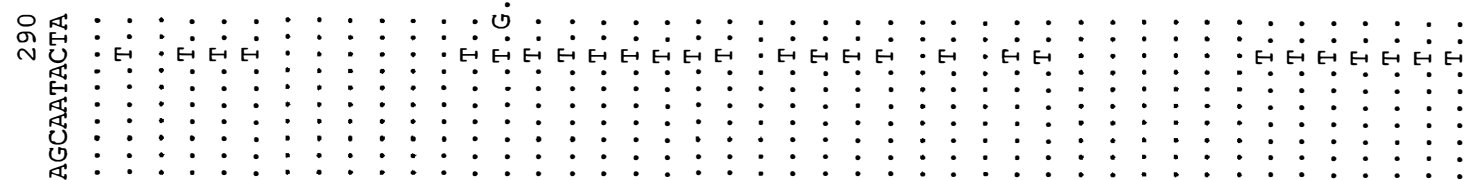<smiles>C=C=[As]=[Se]</smiles>

窟

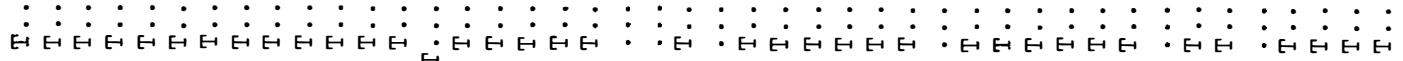

U

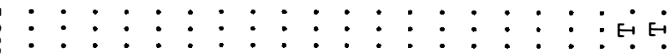

용 芯

西:

:

율

:

ن

$\vdots: \vdots$

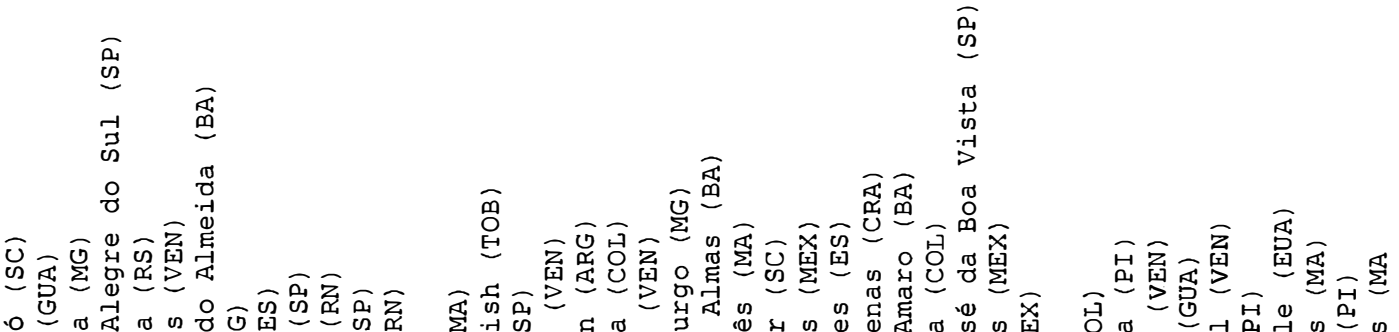

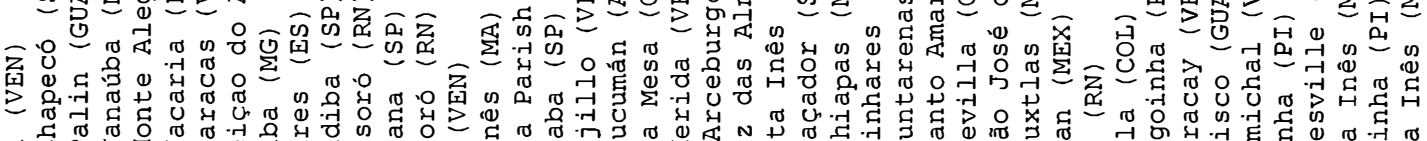

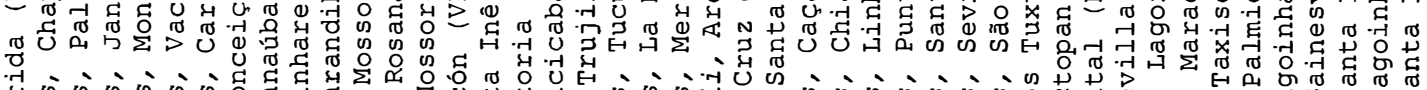

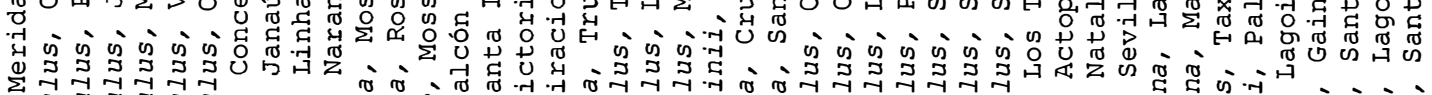

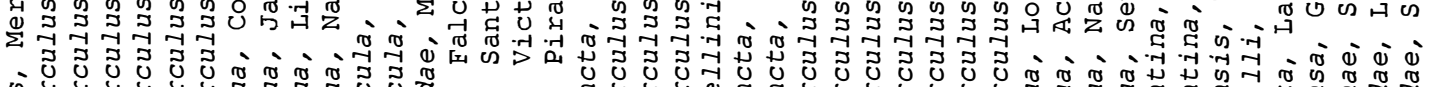

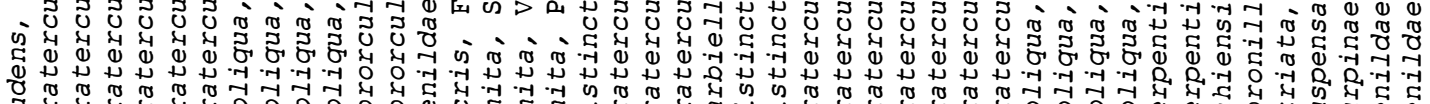

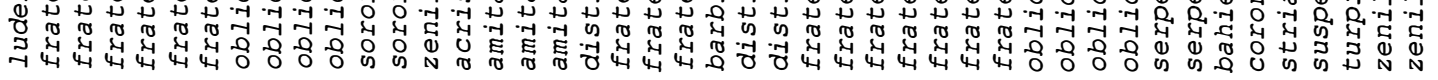

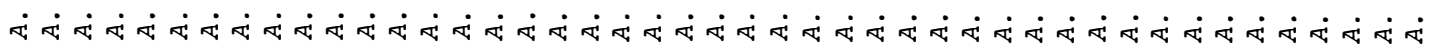




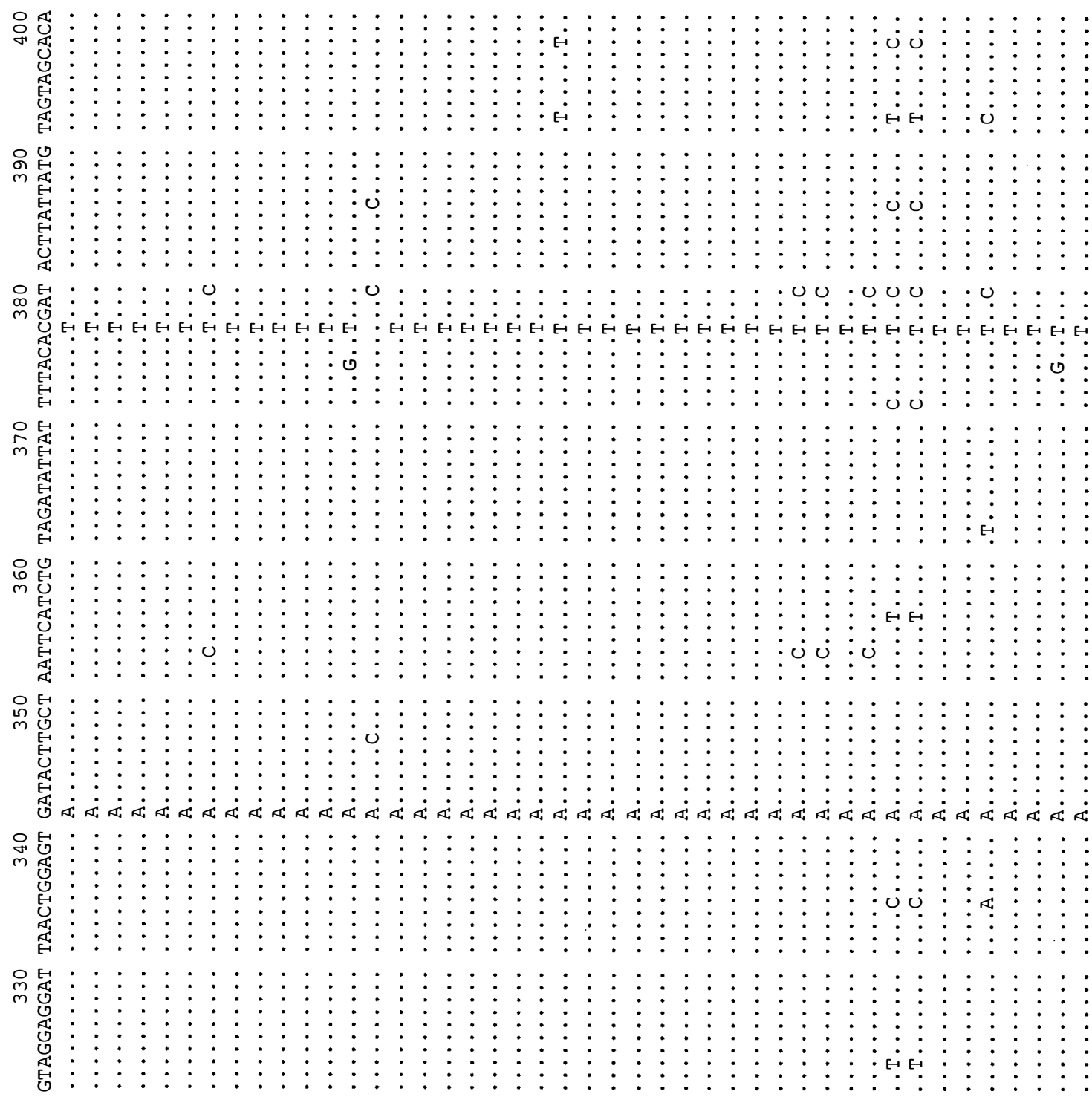

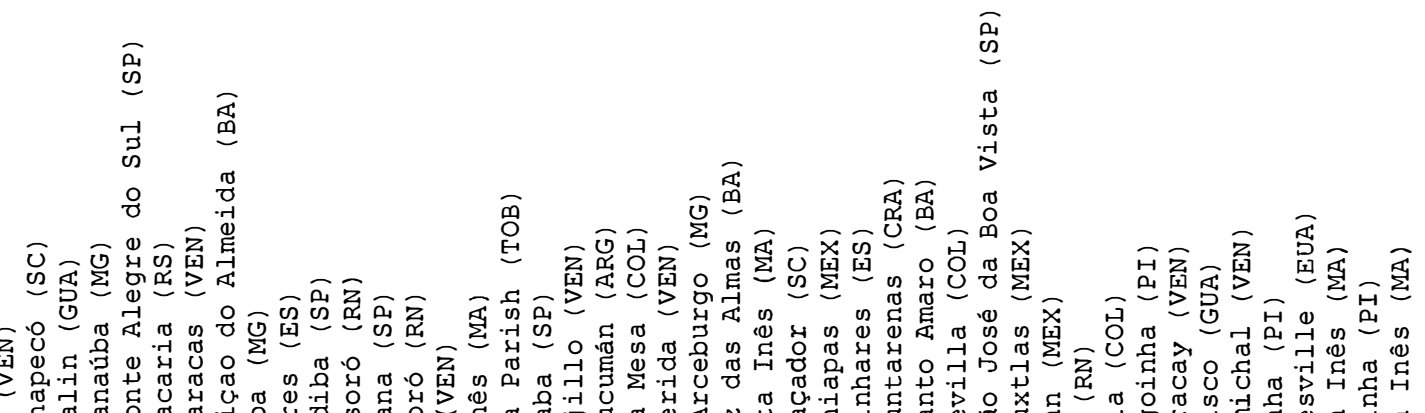

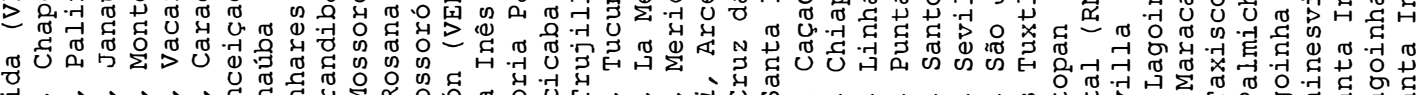

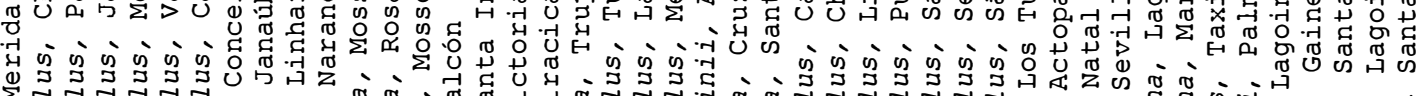

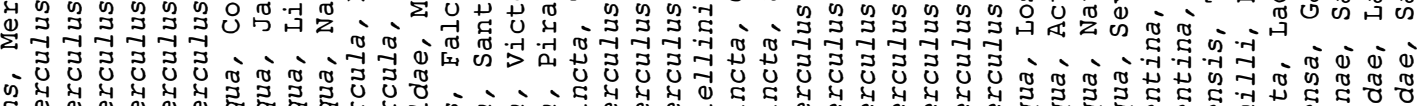

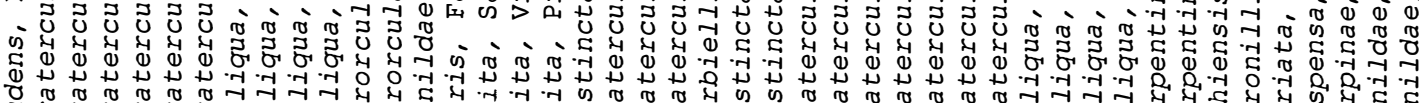

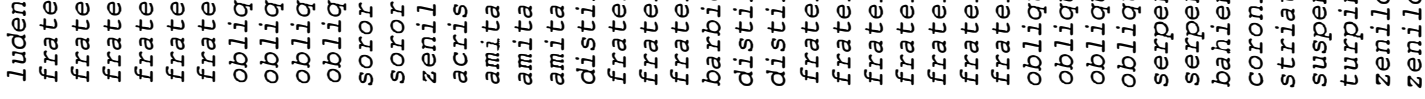

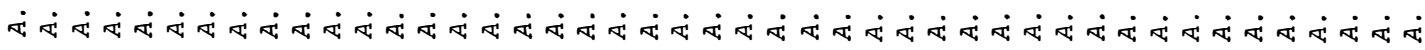




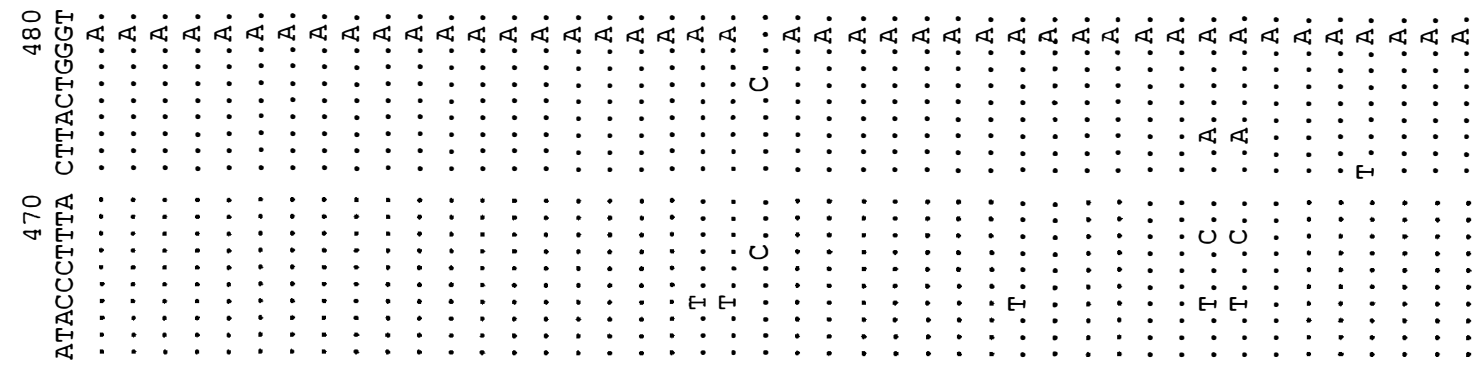

잉

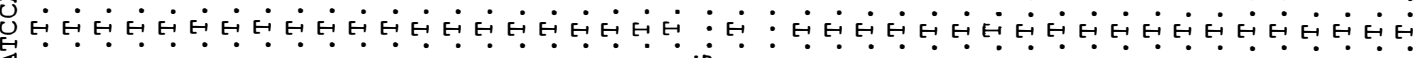

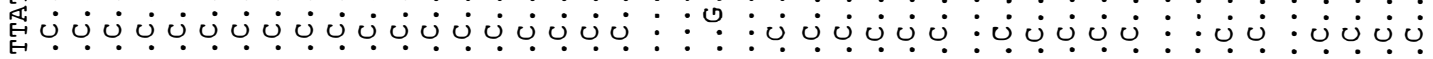

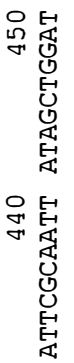

욤벙

$\dot{0}: \dot{0}$

ن ن ن

命芯

品朂

บ บ บ บ บ

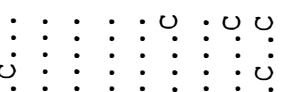

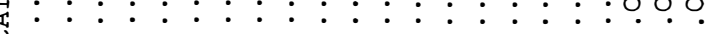

㫐

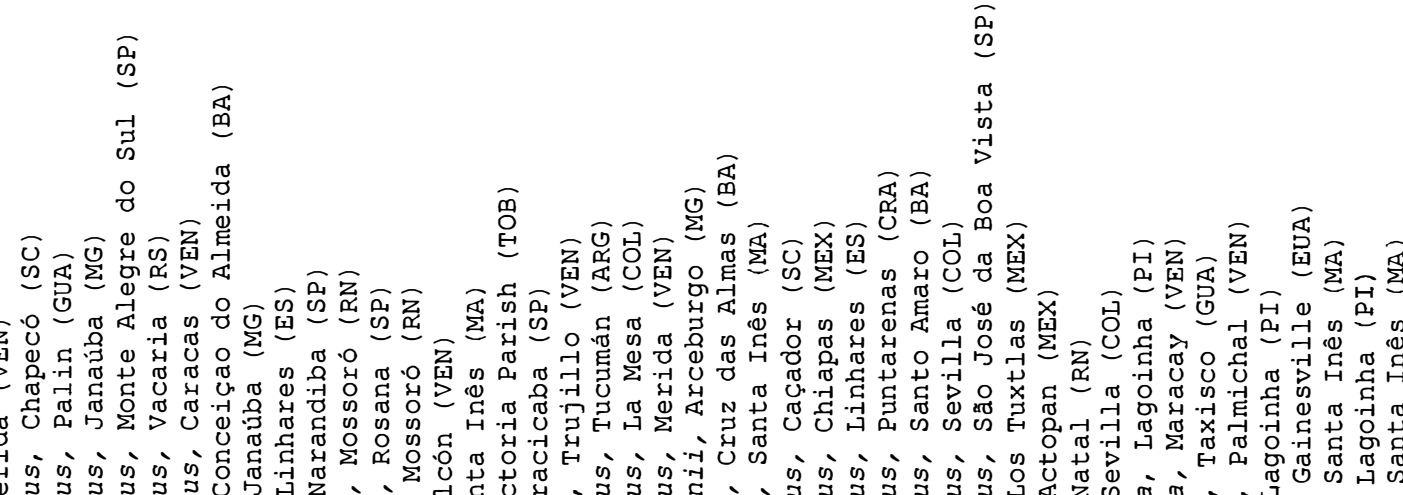

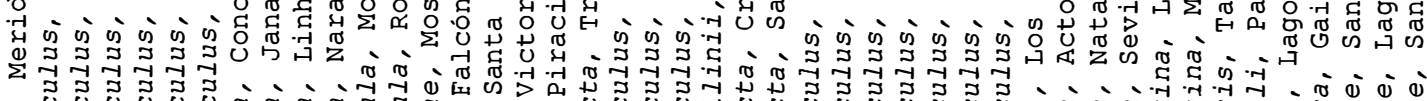

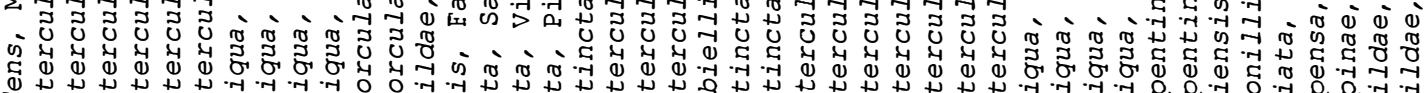

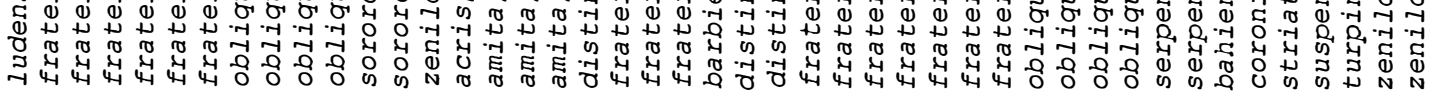

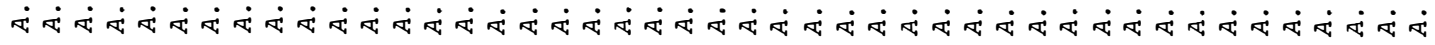




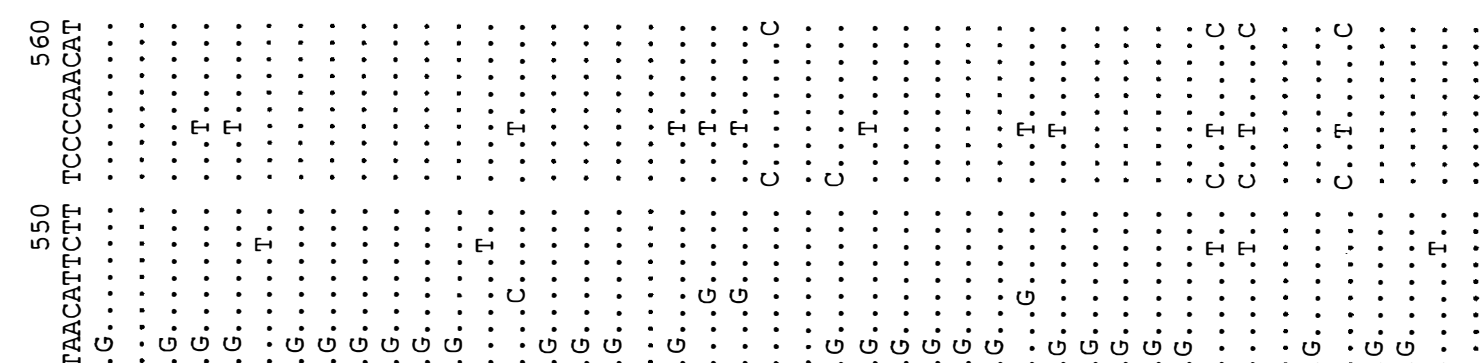

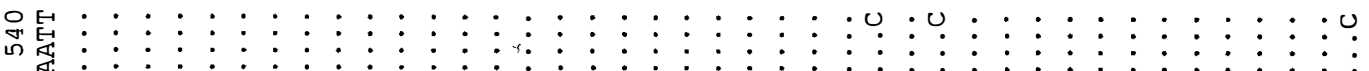

狵

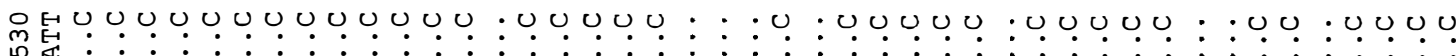

芯:

令曷

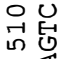

存

息:

유용

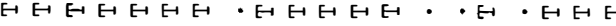

ن

?

品发:

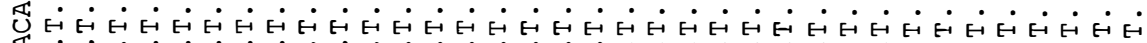
虞:

Вен :

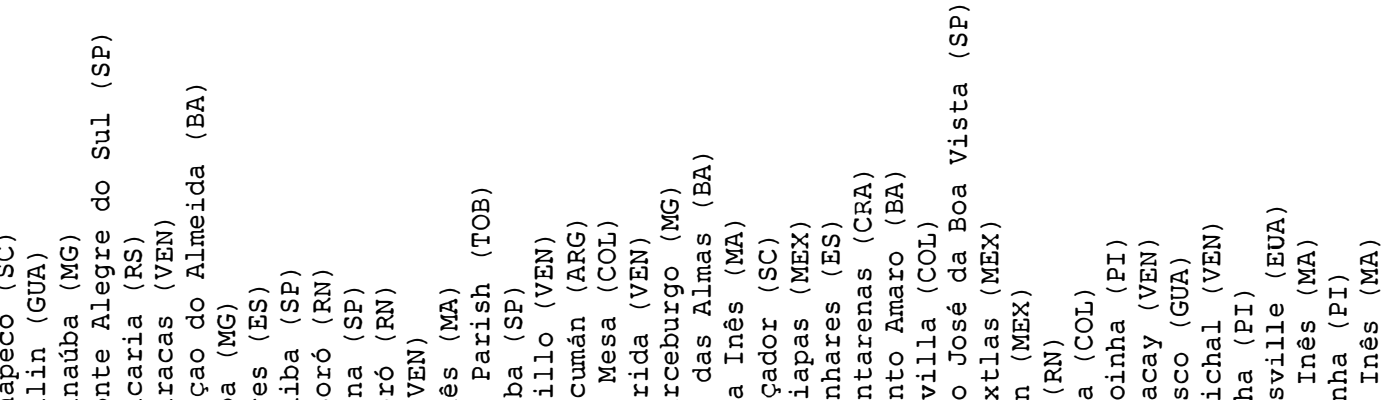

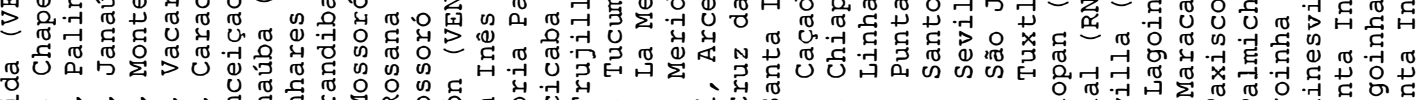

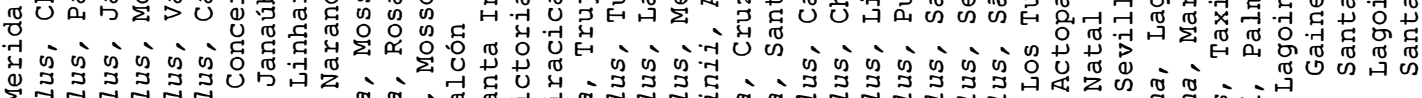

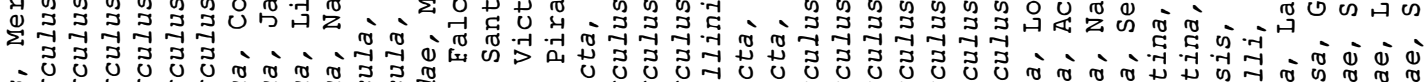

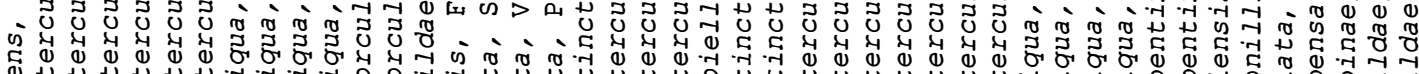
等

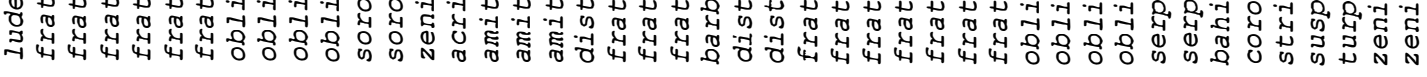

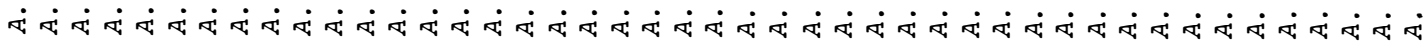




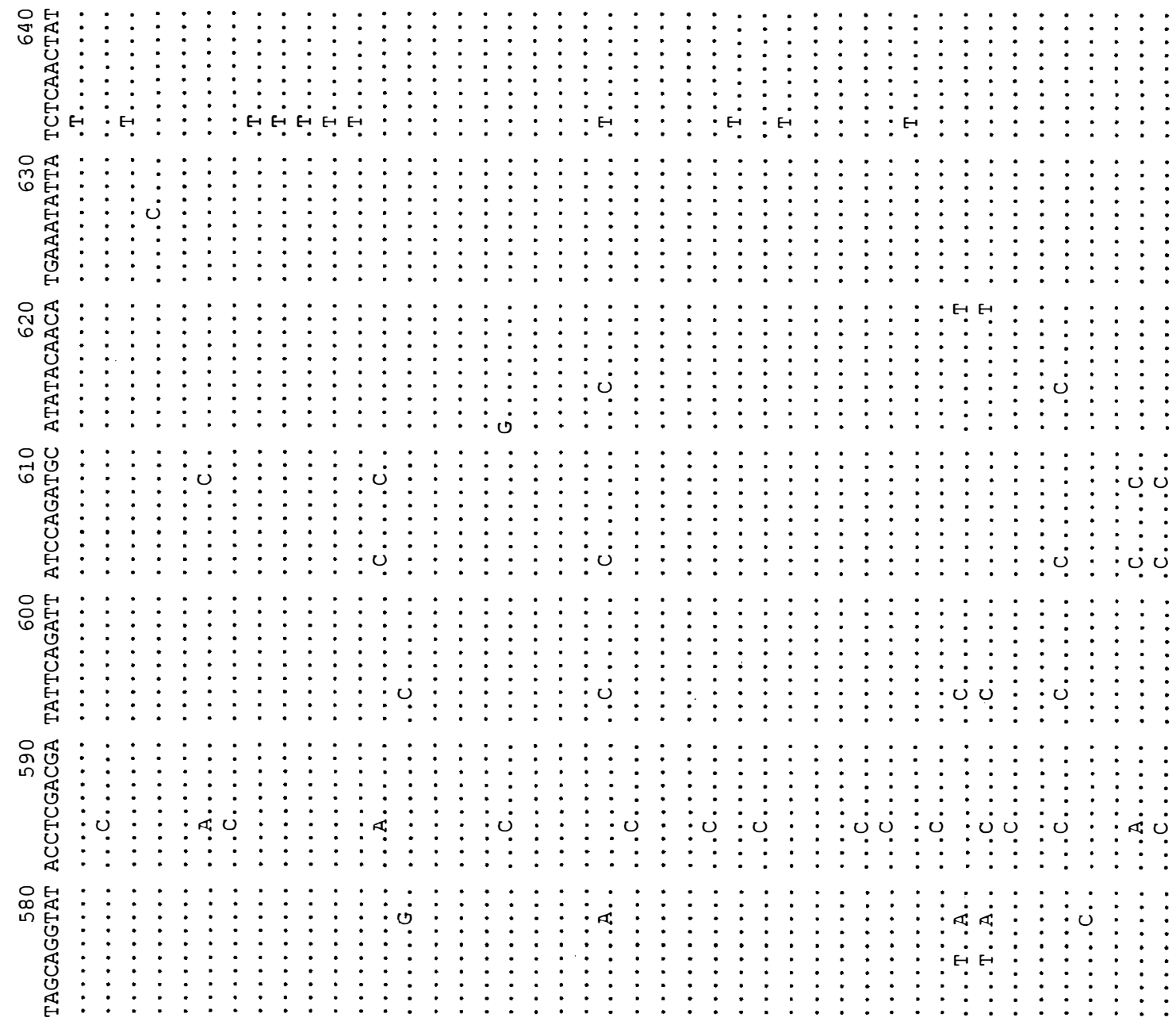

요엉

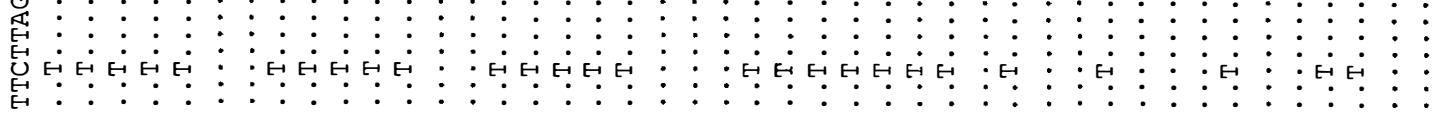

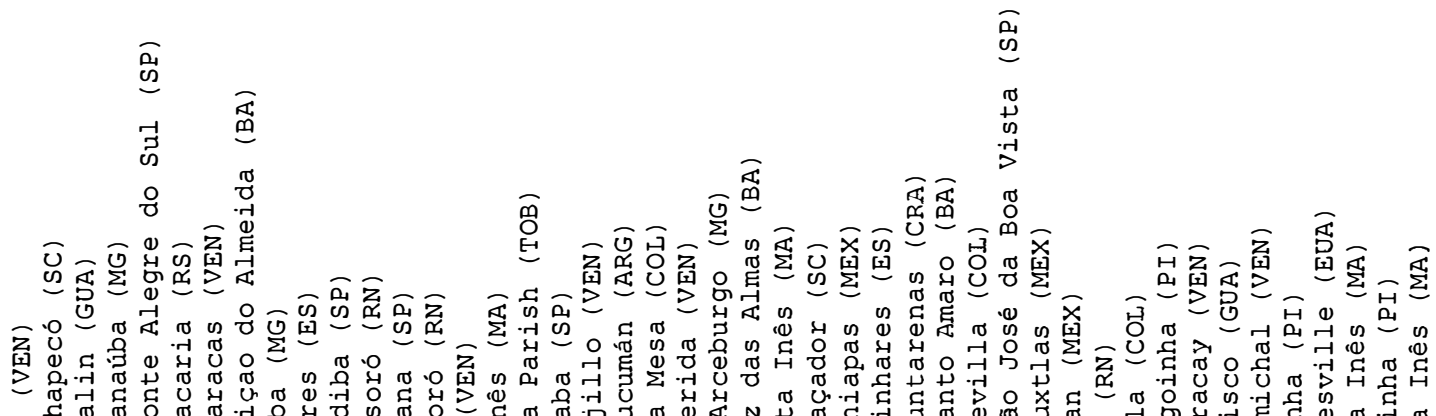

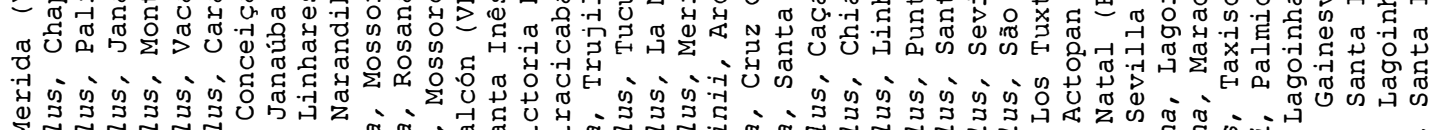

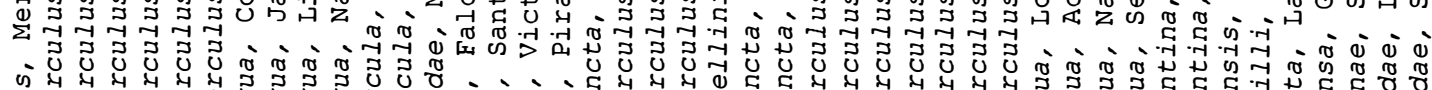

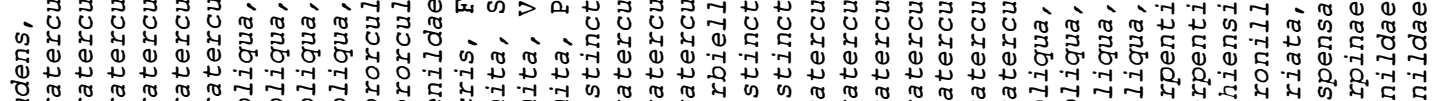

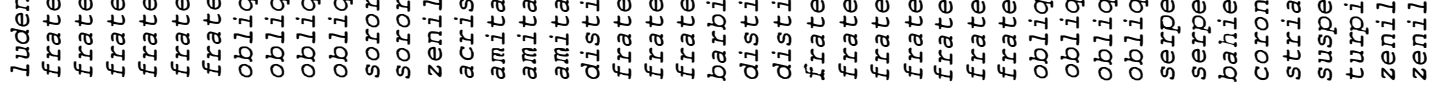
वं வு 


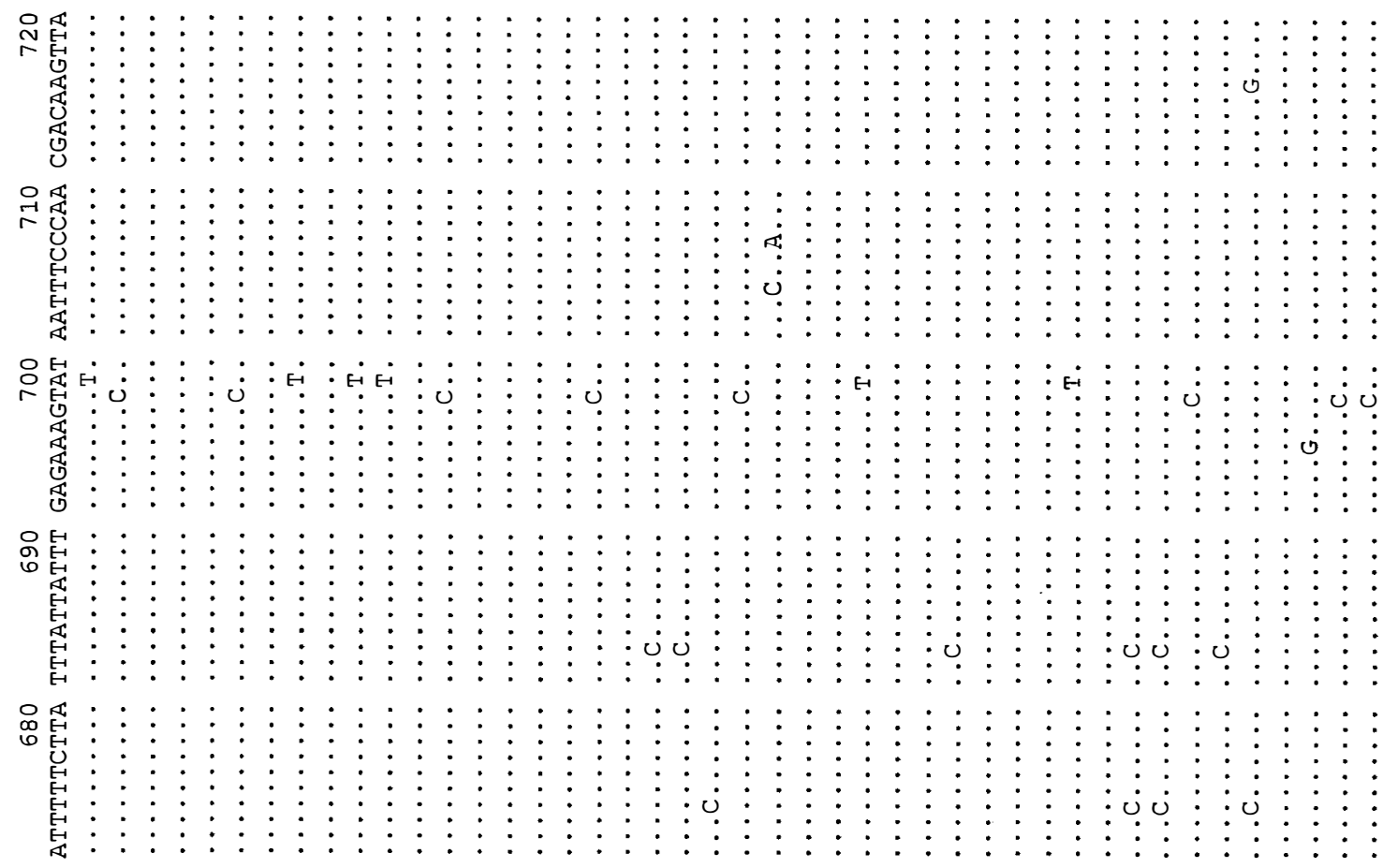

은

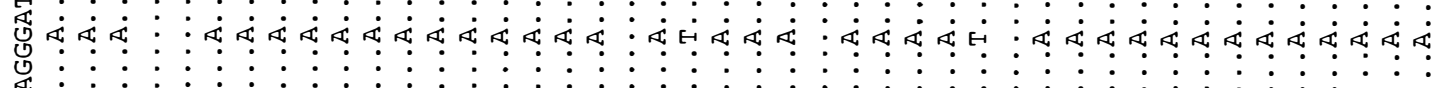
昏

馜芯

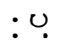

은

䒴

○ U

$: \vdots \vdots \vdots:$

$:: \vdots \vdots \vdots \vdots \vdots \vdots: \vdots \vdots \vdots$

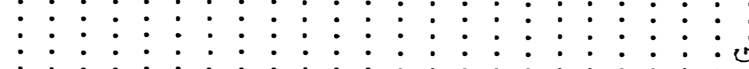

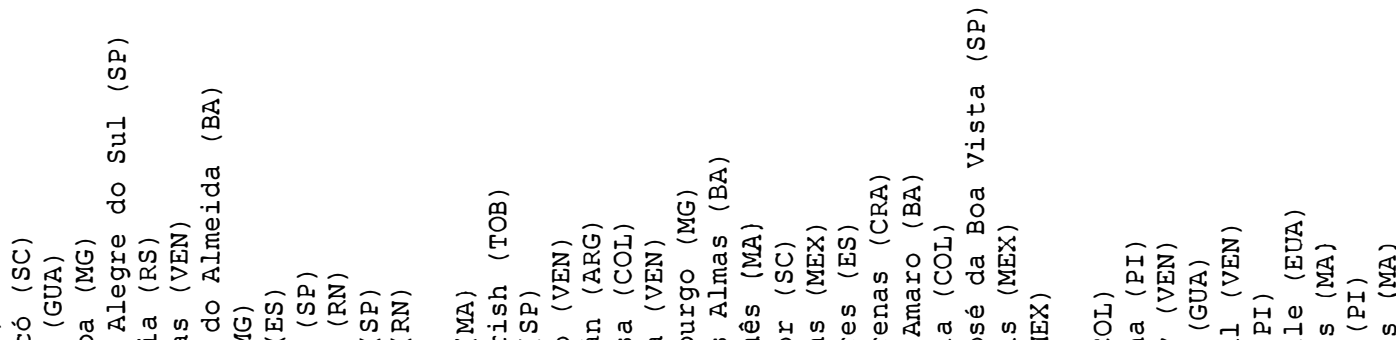

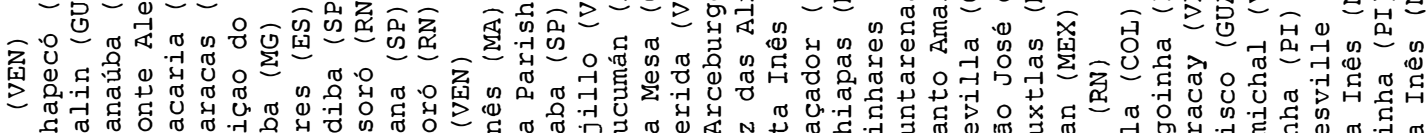

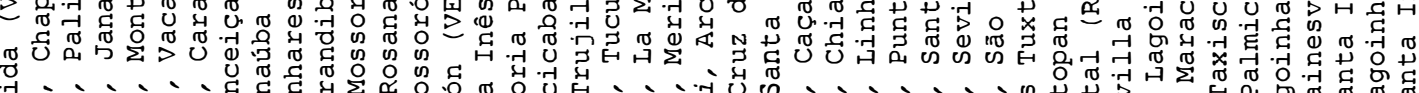

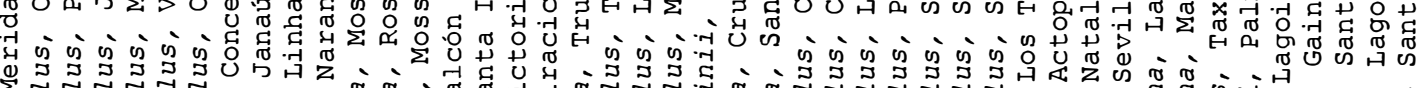

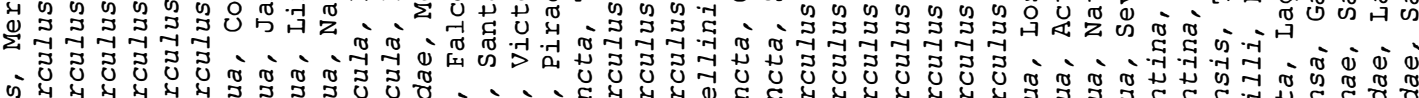

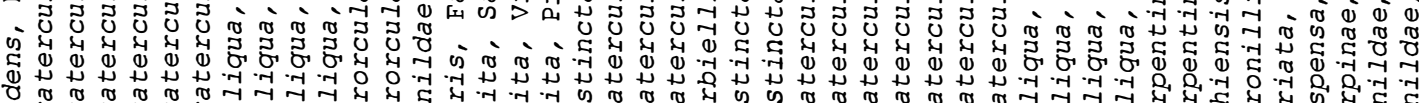

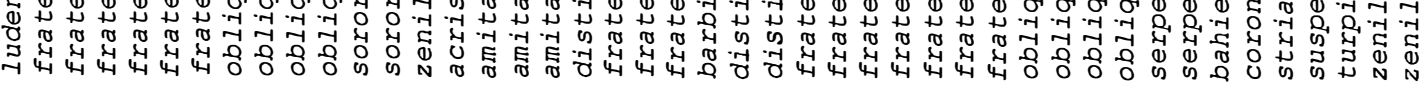

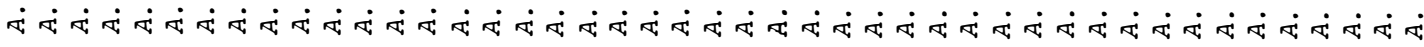




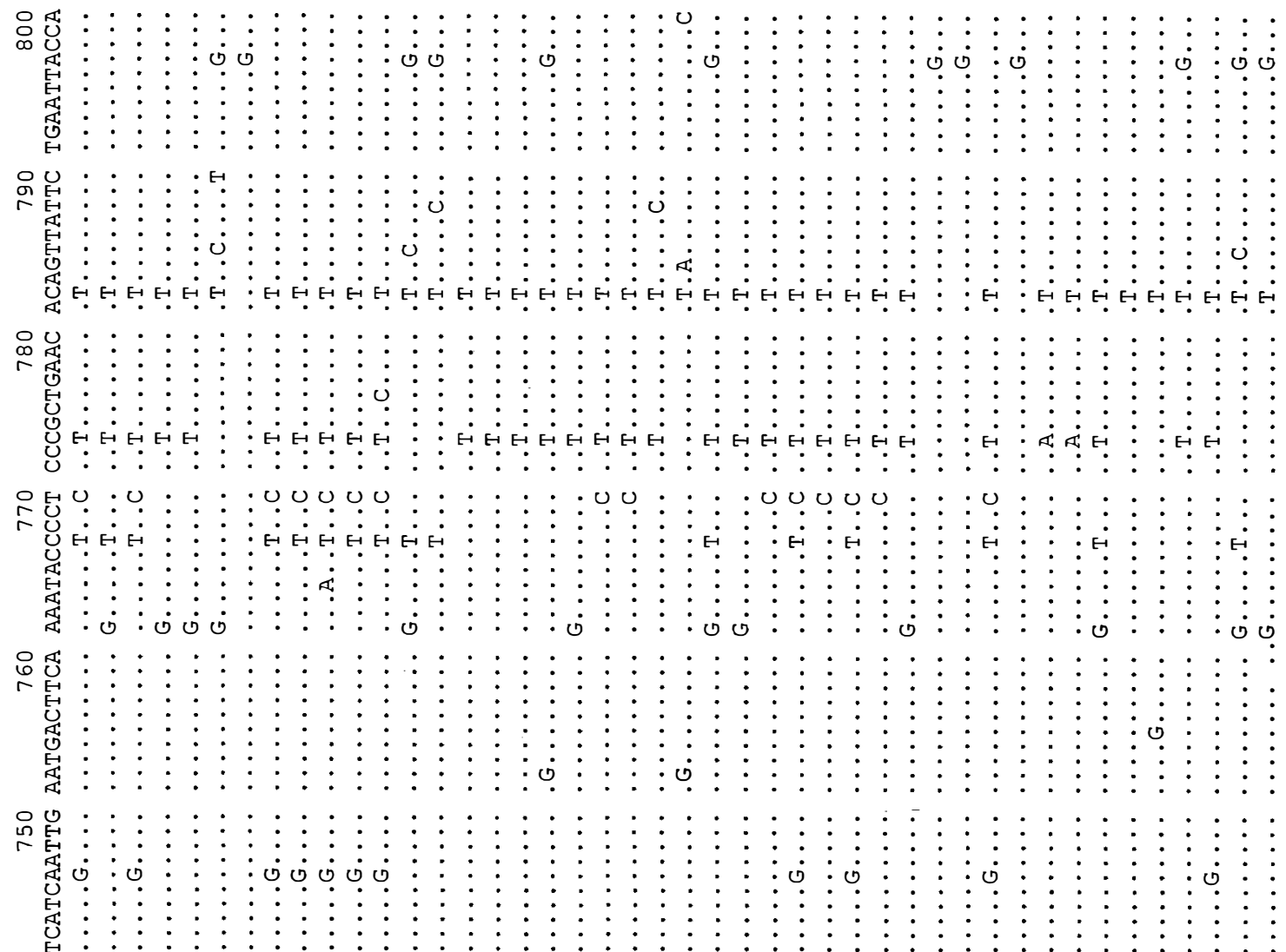

웅 帠:

录

ن

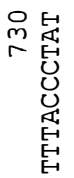

$\vdots \vdots \vdots \vdots \vdots \vdots \vdots \vdots \vdots \vdots$ в

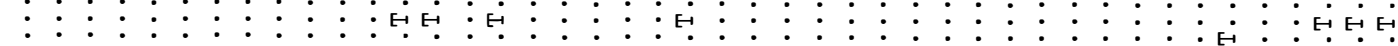

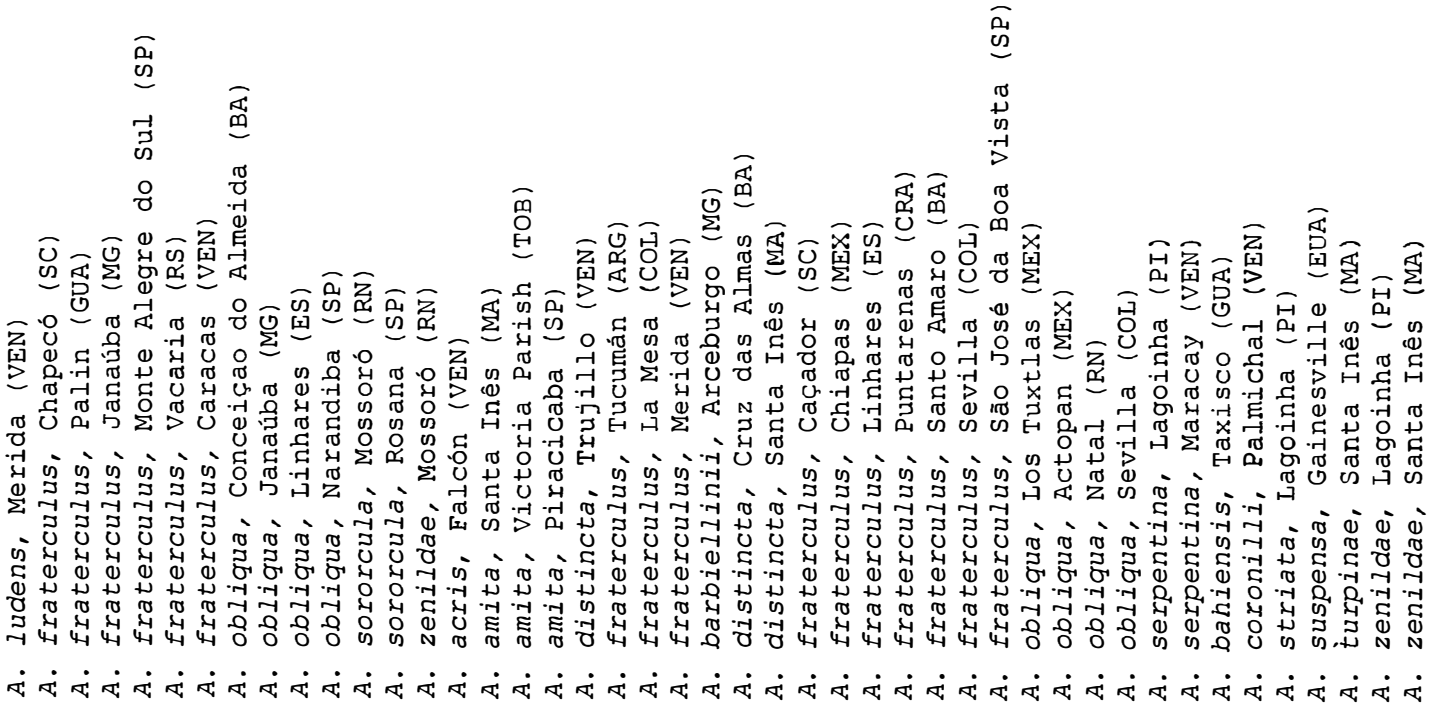




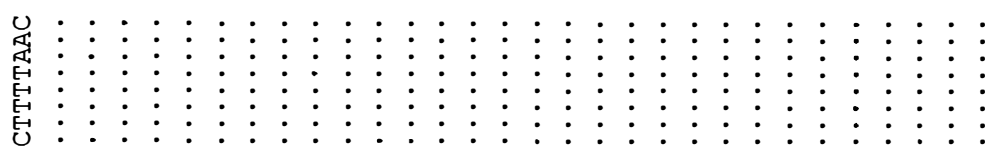

命

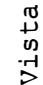

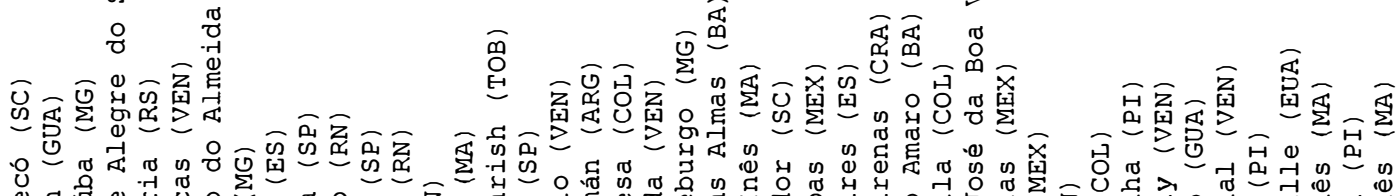

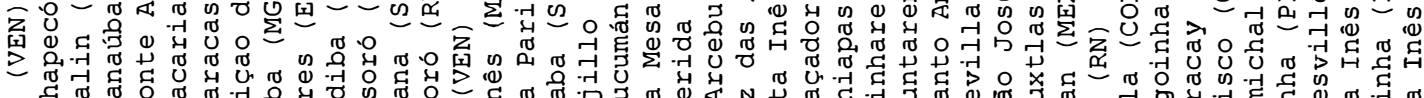

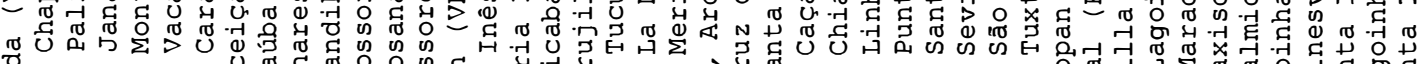

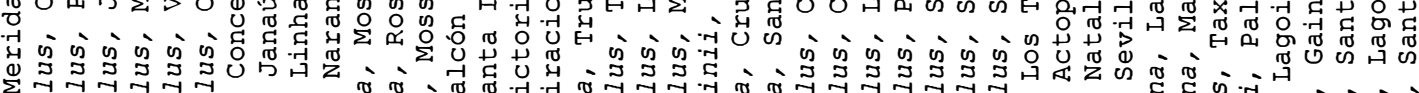
ะ

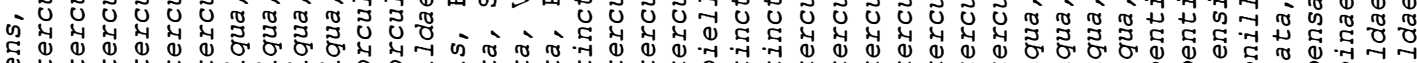
8

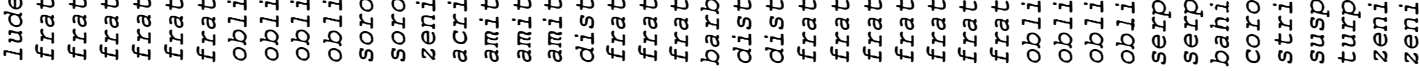

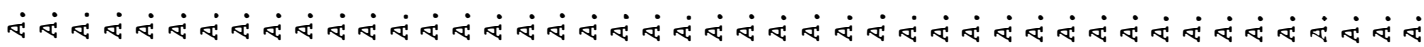




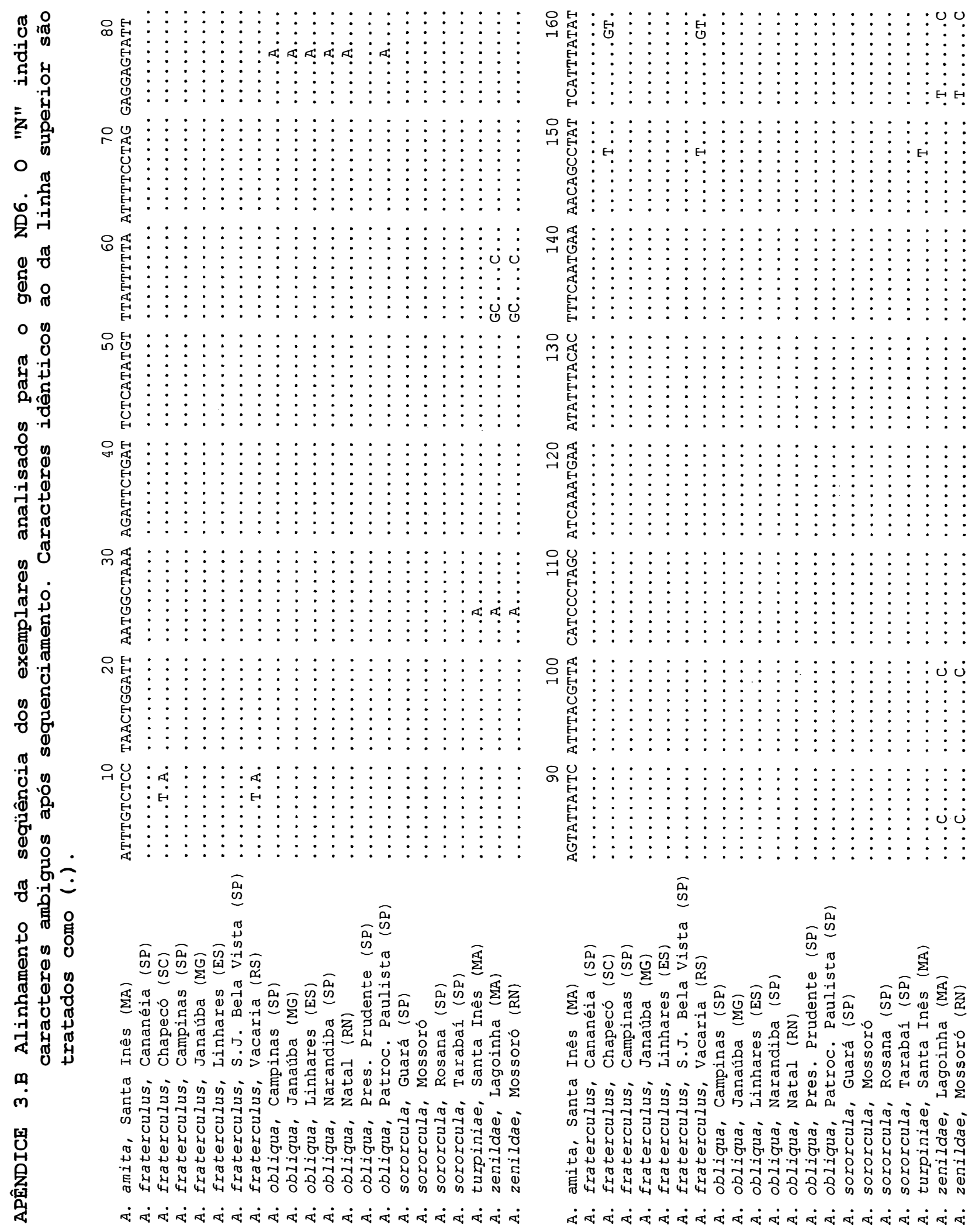




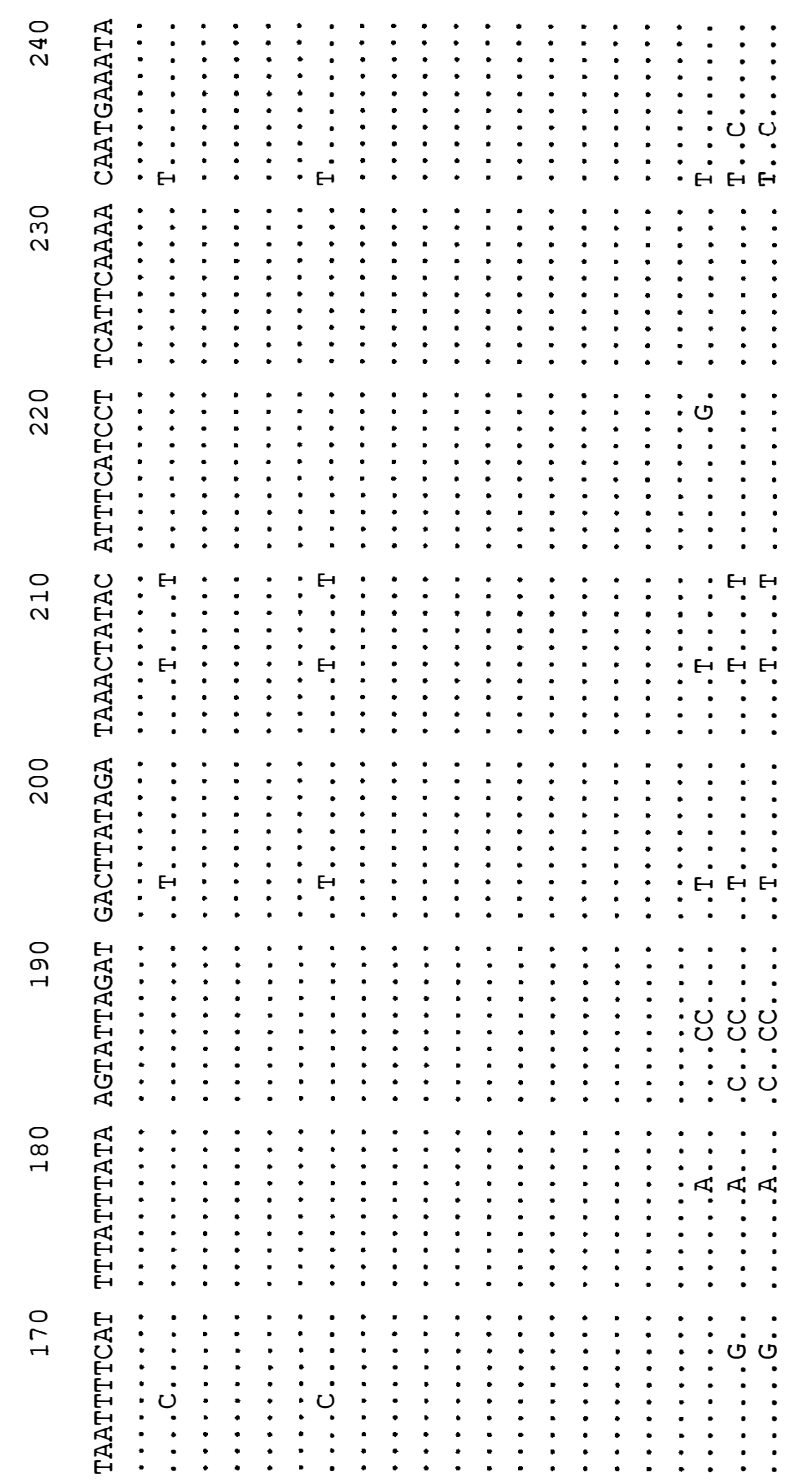

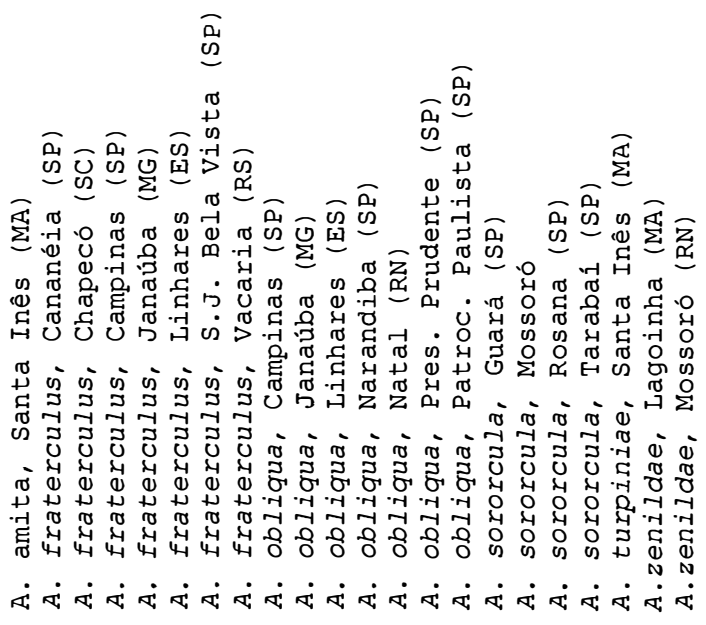

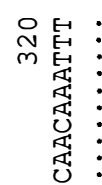

웡: : : : : : : : : : : : : : : : : : :н

西:

最

욨

虫:

ㅇํำ

苆

웅

更

管

온 芯:

息

迶展

品密

दिध
获

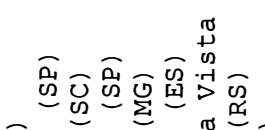
空

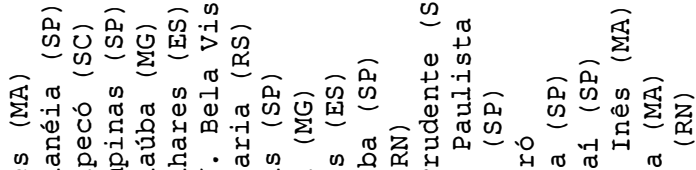

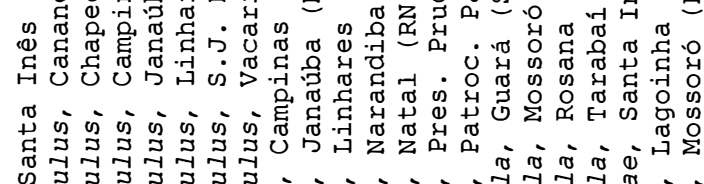 ๙

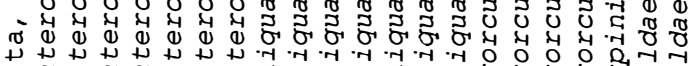

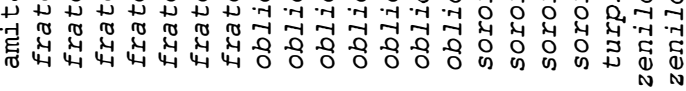

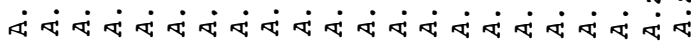




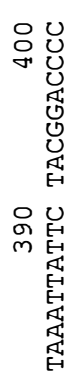

品甭

우ㅇㅝㅕㅇ

읐

还

品䁬

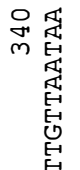

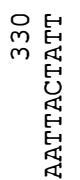

究

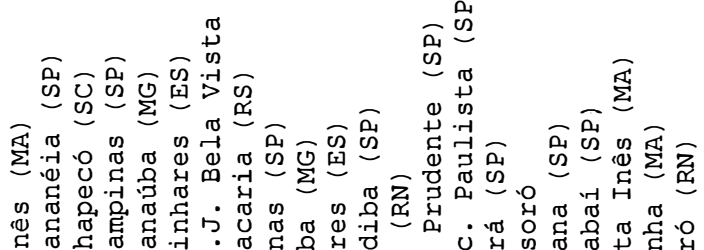

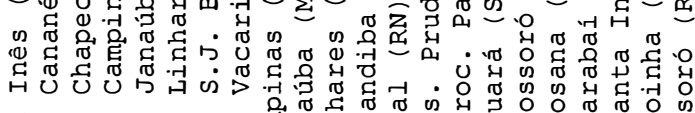

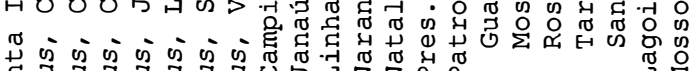

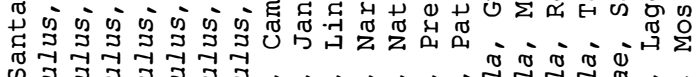
क人

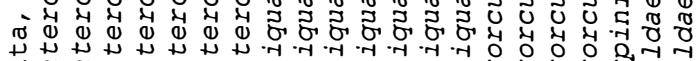

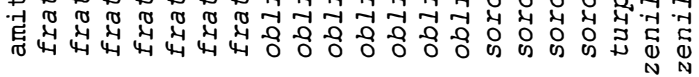

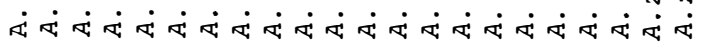
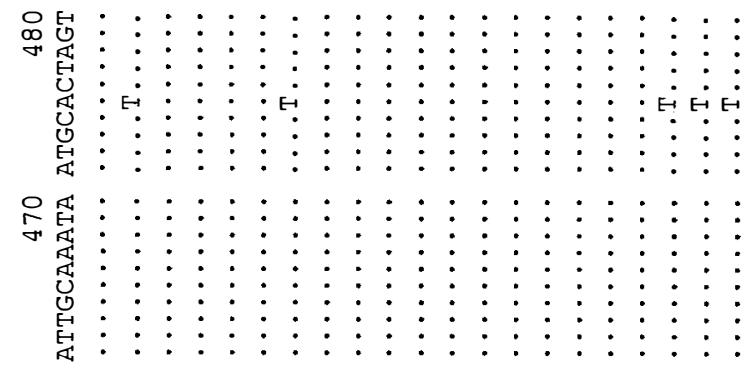

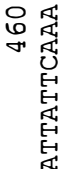

유워

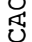

过:

용 透:

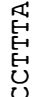

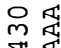

ن

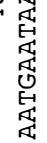

언

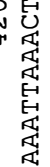

웜볍

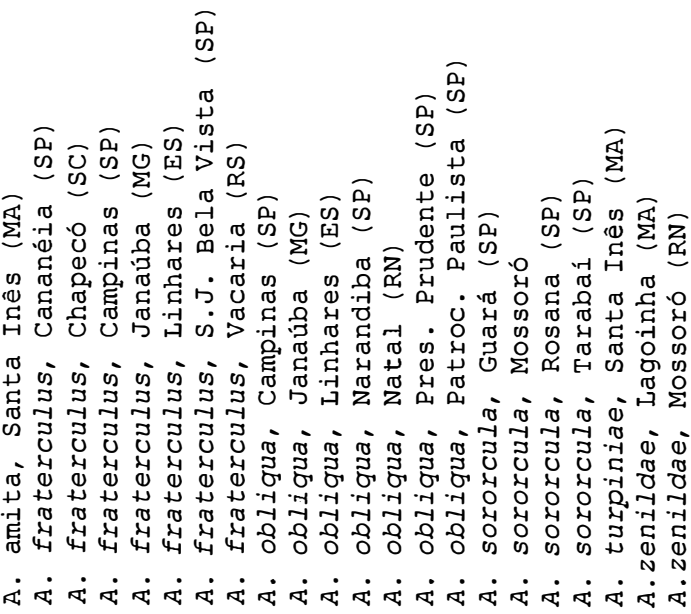



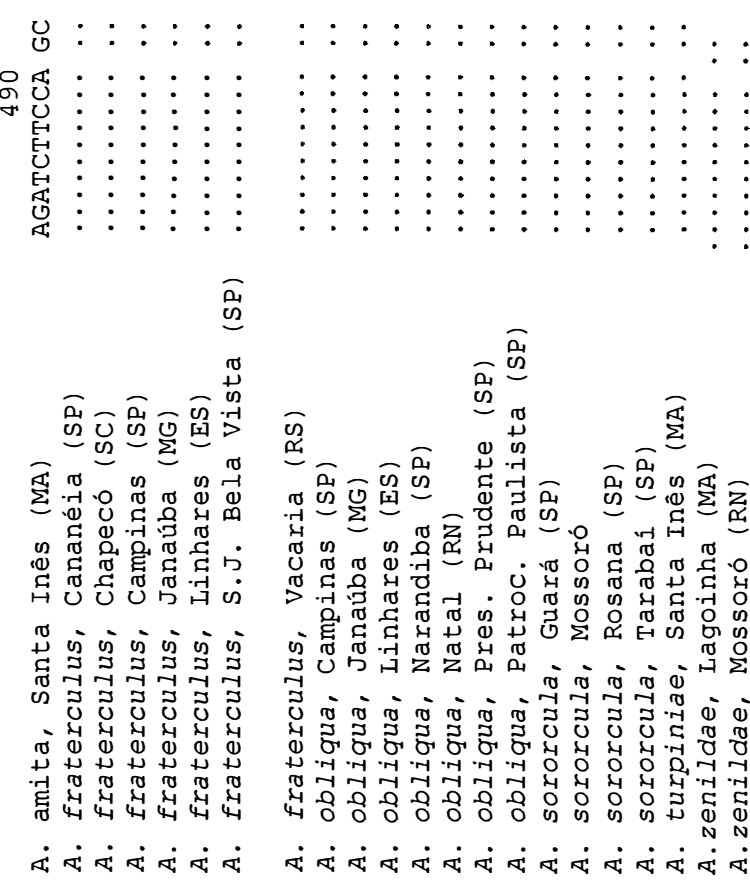

్ㅗㅇ

永

蒋

봉

U

o

站

ช0

न्్

d

容

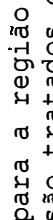

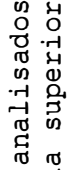

o.

离赵

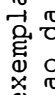

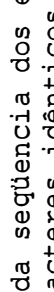

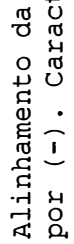

نे

된 곰

盗望
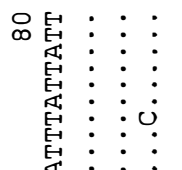

운본

暍:

ОО …

品

䒺

兽

in

楒

웝

守旨

帠

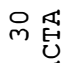

通

哭

올

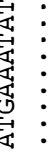

우령

恷:

息:

: :

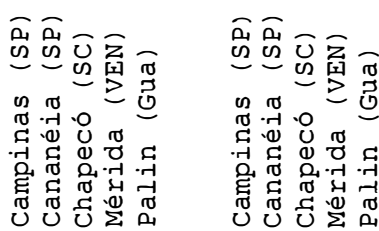

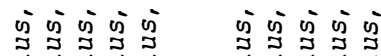

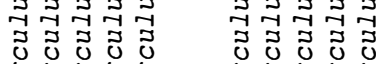

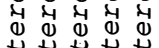

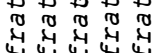

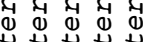

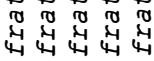

वंखांखं 


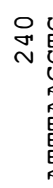

吕芯

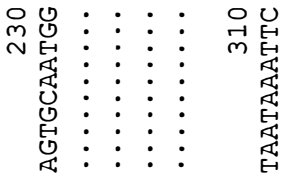

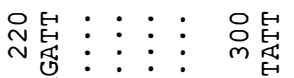

芯 $\vdots \vdots \vdots \vdots$

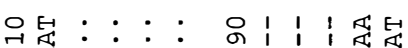

芯

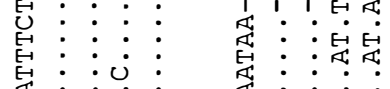

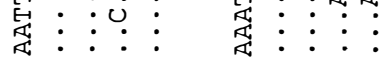

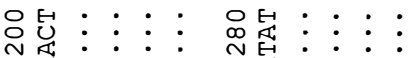

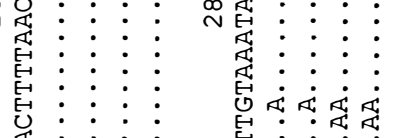

웍

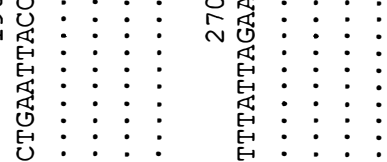

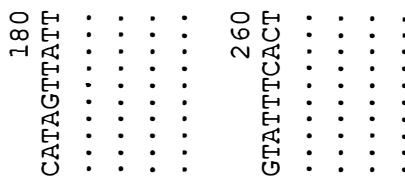

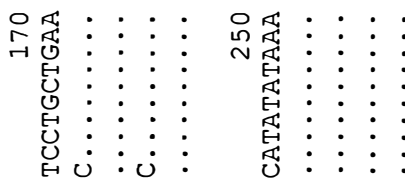

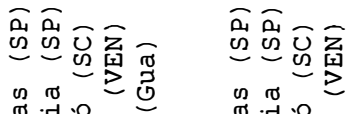

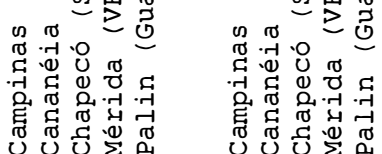

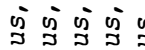

ปี

至

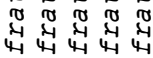

वंख्यव

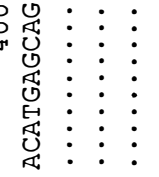

웠

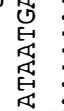

昏的

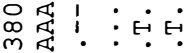

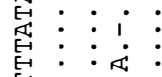

鼠 $\vdots \vdots \vdots \vdots$

옹乐: : 토:

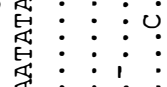

芯

品最百:

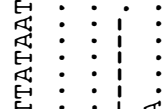

员武i计

m

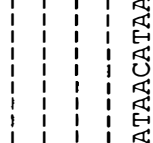

일 $1: 1:$ :

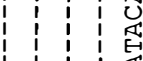

1 $1 \quad 100$

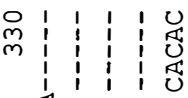

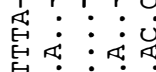

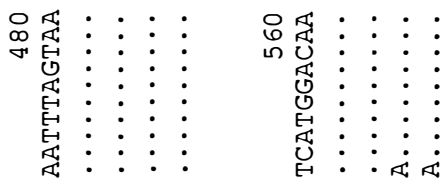

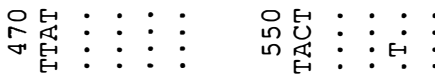

岁 $\vdots \vdots 0 \dot{0}$

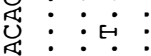

엉

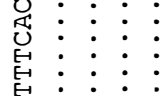

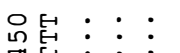

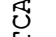

忎 $\vdots \vdots \vdots \vdots$

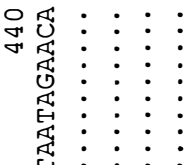

임ํํ

芩

㫐 $\vdots \vdots \vdots \vdots$

웢텅: :

惥:

发

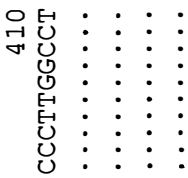

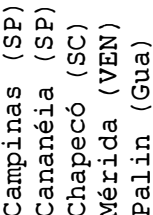

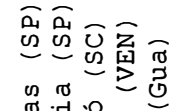

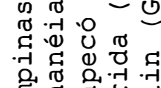

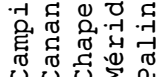

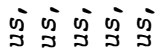

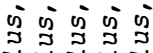

ปี

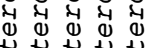

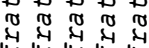

वं ব्व
ปี

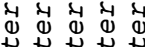

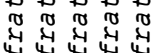

वंख्यव
息 $\vdots \vdots \vdots \vdots$

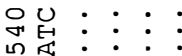

:

芯 $\vdots \vdots \vdots \vdots \vdots$ 导

유웝 : : :

崫 $\vdots \vdots \vdots \vdots$ 芯 $\vdots \vdots \vdots \vdots$

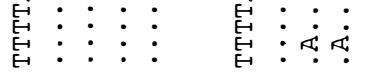

设芯!:

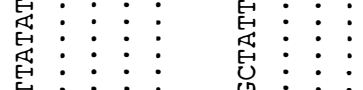

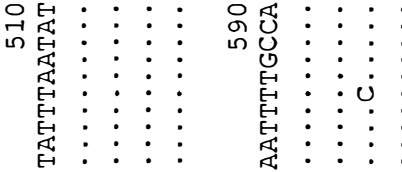

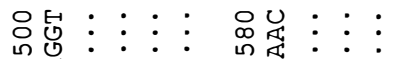

芯: :

芯: $\vdots \vdots$ 舅

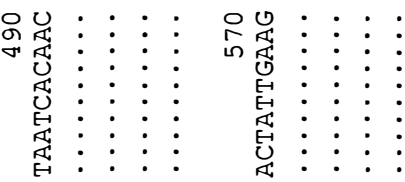

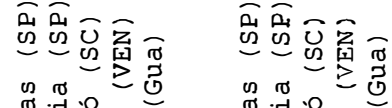

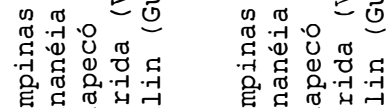

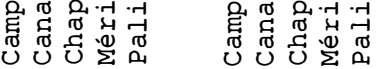

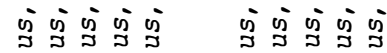
ปี ปี

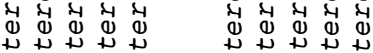

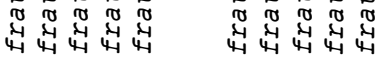

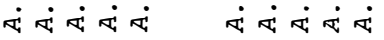

